\title{
Jordan: 2010 Article IV Consultation-Staff Report and Public Information Notice
}

Under Article IV of the IMF's Articles of Agreement, the IMF holds bilateral discussions with members, usually every year. In the context of the 2010 Article IV consultation with Jordan, the following documents have been released and are included in this package:

- The staff report for the 2010 Article IV consultation, prepared by a staff team of the IMF, following discussions that ended on July 18, 2010, with the officials of Jordan on economic developments and policies. Based on information available at the time of these discussions, the staff report was completed on August 31, 2010. The views expressed in the staff report are those of the staff team and do not necessarily reflect the views of the Executive Board of the IMF.

- $\quad$ A Public Information Notice (PIN).

The policy of publication of staff reports and other documents allows for the deletion of market-sensitive information.

Copies of this report are available to the public from

International Monetary Fund • Publication Services $70019^{\text {th }}$ Street, N.W. • Washington, D.C. 20431

Telephone: (202) 623-7430 • Telefax: (202) 623-7201

E-mail: publications@imf.org Internet: http://www.imf.org

\section{International Monetary Fund Washington, D.C.}


INTERNATIONAL MONETARY FUND

JORDAN

\section{Staff Report for the 2010 Article IV Consultation}

Prepared by Staff Representatives for the 2010 Article IV Consultation with Jordan

Approved by David Owen and Thomas Dorsey

August 27, 2010

\section{EXECUTIVE SUMMARY}

\section{Background}

As one of the most open economies in the Middle East, Jordan has been adversely affected by the global and regional economic crisis. However, prudent fiscal and monetary management has minimized the effects of these external shocks on the domestic economy. There has been progress in reducing near-term risks and in advancing structural reforms, and further fiscal consolidation over the medium term will be critical to achieving private sector-led growth and reducing vulnerabilities.

\section{Policy challenges}

The key challenges facing the authorities are to cautiously manage the downturn in the economy, continue to advance structural reforms that will entrench stability and sustain medium-term employment and potential output growth, and in so doing lower Jordan's underlying fiscal and external vulnerabilities.

\section{Key recommendations}

- Undertake fiscal consolidation in 2010, narrowing the overall deficit relative to the 2009 outturn, reaching a deficit of about 6 percent of GDP.

- Target an overall deficit of about 3 percent of GDP over the medium term, to reduce vulnerabilities affecting the economy. This is consistent with a decisive further decline in the public debt-to-GDP ratio, maintaining the ratio below the legislated 60 percent limit. Such an outturn will require further rationalization of public expenditures (particularly the size of the civil service wage bill) and additional revenue-raising measures.

- While an accommodative monetary policy stance in 2009-10 has been appropriate, there is likely little room for further monetary stimulus. The authorities should continue to stand ready to tighten monetary conditions if inflation accelerates or there are pressures on the balance of payments.

- Maintain the pegged exchange rate regime, which remains appropriate for Jordan, and has been a key pillar of financial stability. The dinar real exchange rate is broadly in line with medium-term fundamentals.

- Continue to strengthen banking supervision to enable Jordanian banks to remain robust to internal and external shocks.

- Implement structural reforms, including further liberalization of the water and energy sectors, and the structure of the civil service. Further improve the business environment for the private sector, including by putting in place a sound framework to control for fiscal risks involved in public-private partnerships.

- $\quad$ Further improve the coverage, quality, and timeliness of economic statistics, particularly for labor and property markets, which would aid policy formation and economic monitoring. 
Contents

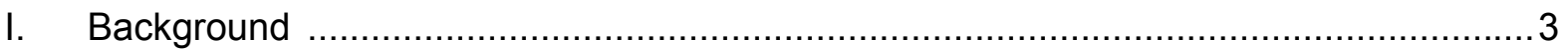

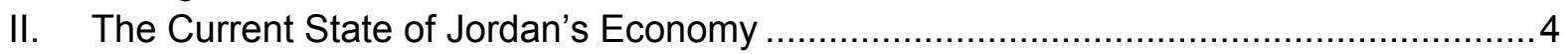

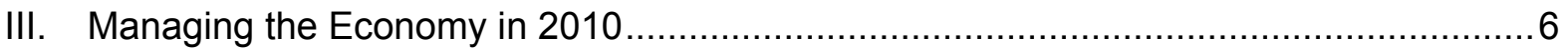

A. Fiscal Policy: Consolidation Amidst a Cyclical Downturn .................................... 6

B. Monetary and Exchange Rate Policy: Resuscitating Private Credit and Maintaining External Competitiveness ................................................. 8

C. Financial Sector Policy: Enhancing Regulation of a Robust Banking System ...........9

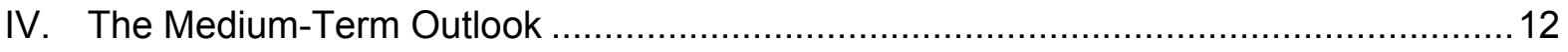

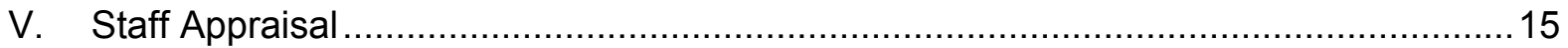

Boxes

1. Business Cycle Linkages Between Jordan and Major Trading Partners ...................... 5

2. Jordan's Economic Recovery .......................................................................... 6

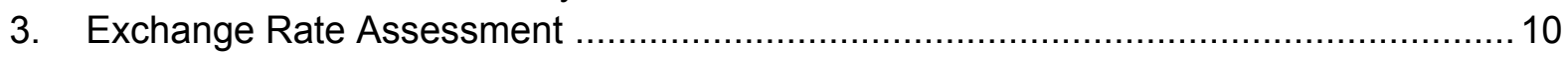

Figures

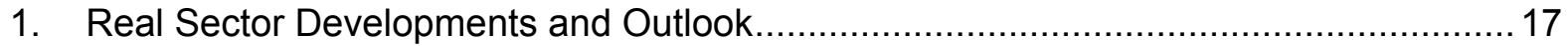

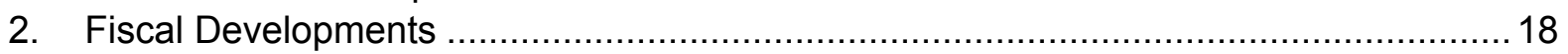

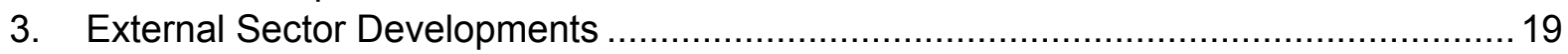

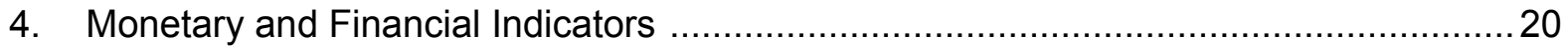

Tables

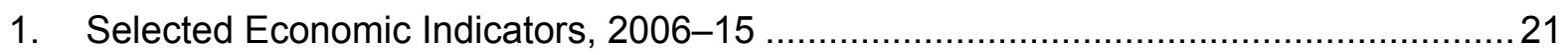

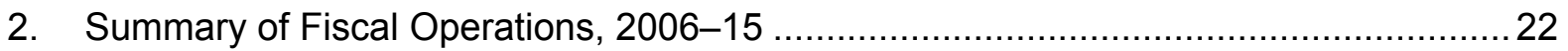

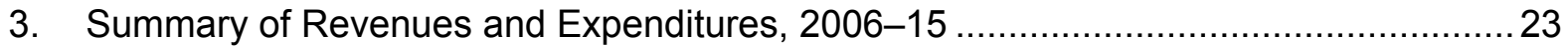

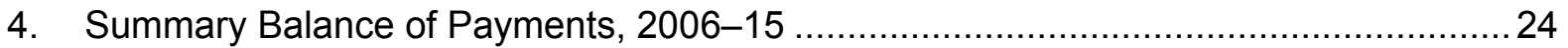

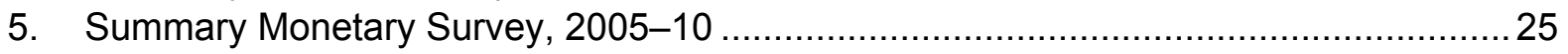

6. Summary Accounts of the Central Bank of Jordan, 2005-10 ................................ 26

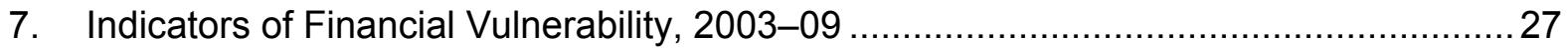

Appendices

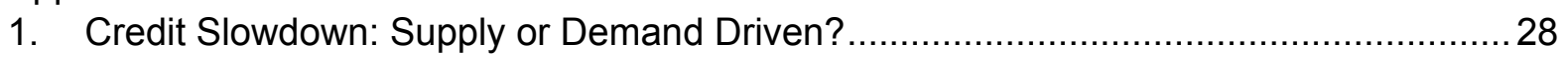

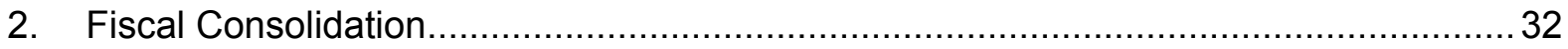

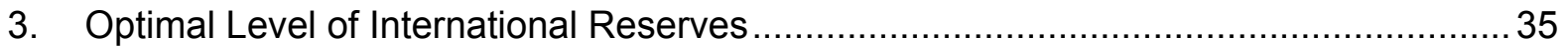

4. Interest Margin Determinants in the Jordanian Banking System ................................ 39

5. FSAP Recommendations and Banking Supervision Reforms ..................................42

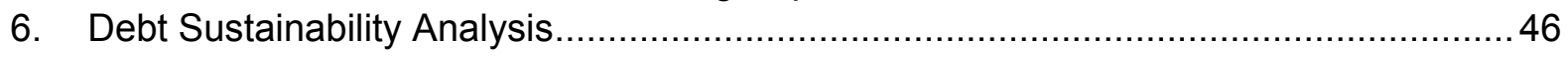

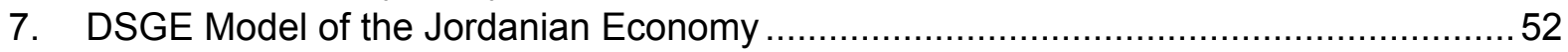




\section{BACKGROUND ${ }^{1}$}

1. Following a decade of strong growth, the Jordanian economy has slowed considerably, largely due to the global and regional downturn. Annual real GDP growth averaged about 6 percent between 2000-08, supported by the implementation of sound economic policies and favorable external conditions. Consistent with the global economic slowdown, output growth in Jordan fell sharply in 2009 , and economic activity is expected to pick up modestly in 2010 , in line with the recovery of key regional trading partners.

2. The global economic downturn adversely affected economic activity. Real GDP growth fell from almost $7 \frac{1}{3}$ percent in 2008 to $2 \frac{1}{3}$ percent in 2009 , mainly due to weaker activity in the finance, manufacturing, and trade sectors (Table 1 and Figure 1). The unemployment rate remains stubbornly high (13 percent at end-2009). The output gap widened in 2009 and is expected to remain negative in 2010. Headline inflation declined steadily through 2009 to near zero, in line with lower world commodity prices, although core inflation has remained stable at around 3 percent $y-0-y$. For 2010 headline inflation is projected to increase in line with imported commodity (energy and food) prices.

3. In common with many emerging market countries adversely affected by the global growth downturn, Jordan's already-difficult 2009 fiscal position was made worse by a significant deterioration in external grants. While an increase in capital spending-to support domestic activity - was largely offset by lower commodity subsidies, a cyclical weakening in domestic revenues and a dramatic downturn in external grants induced a widening of the overall deficit by more than 3 percentage points of GDP, reaching $81 / 2$ percent of GDP in 2009 . As a result, the debt-to-GDP ratio rose to about 56 percent at end-2009 (Tables 2-3, and Figure 2).

4. Lower commodity prices helped to improve Jordan's external position. The current account deficit narrowed to 5 percent of GDP in 2009 (from 91/2 percent in 2008), on the back of strong tourism receipts and remittances and lower oil import spending that more than offset a decline in exports (Table 4 and Figure 3). Foreign direct investment (FDI) and other inflows comfortably financed the current account deficit, and allowed official foreign reserves to reach a record high of $\$ 11$ billion (equivalent to 8 months of imports) by end-2009. In recent months the authorities have revised their historical balance of payment accounts for 2000-08, in order to better account for FDI flows and reduce the size of errors and omissions.

5. The government (formed in December 2009) supports an ambitious program of structural reforms designed to develop the private sector. The Jordanian parliament was dissolved by King Abdullah in November 2009, allowing the government to progress with previously-stalled market reforms. The main policy priorities for the government (led by Prime Minister Rifai) include: stimulation of economic growth and private investment; development of a skilled labor force; enhancing political participation; protection of the poor; facilitating growth and security through large-scale infrastructure investments; and improving the

\footnotetext{
1 This report is based on discussions held in Amman during July 6-18, 2010. The staff team comprised Messrs. Cashin (head), EI Said, and Poghosyan, Mmes. Ter-Martirosyan and Wolde (all MCD) and Mr. Arslanalp (MCM). Ms. Abdelati (OED) and Ms. Sahay (MCD) also joined the discussions. Staff met with the Prime Minister, the Minister of Finance, the Governor of the Central Bank of Jordan, a number of other members of cabinet, senior government officials, private sector representatives, and donors. The mission issued a Concluding Statement, and participated in a joint press conference with the authorities.
} 
level and quality of public services. New parliamentary elections are due to take place on November 9, 2010.

6. Near-term risks to the economic outlook remain tilted to the downside, given uncertainties regarding world commodity-price developments, as well as fragile regional and global economic conditions. If the economic recovery in Gulf Cooperation Council (GCC) countries-to which the Jordanian business cycle is closely linked-proves to be slower than anticipated, this may adversely affect external flows (Box 1). Developments in Southern Europe will likely have little impact on Jordan-any direct spillover through financial channels would be limited since Jordan's financial sector has no substantial links to European assets.

\section{The CuRRENT State of Jordan's Economy}

7. Despite an expected modest rebound in economic growth in $\mathbf{2 0 1 0}$ to about $3 \frac{1}{2}$ percent, output growth remains well below potential, reflecting slowly-recovering global and regional conditions (Box 2). ${ }^{2}$ Real GDP increased by only 2 percent $y-0-y$ in the first quarter of $2010,{ }^{3}$ while inflation picked up to $51 / 3$ percent y-o-y in June 2010 , driven mostly by higher international fuel and food prices. The external current account deficit is expected to widen in 2010 (reaching 7 percent of GDP), as expenditure on imported commodities rises, and is only partially offset by healthy tourism receipts and a rebound in exports. Official foreign exchange reserves, a comfortable $\$ 10.4$ billion (equivalent to $7 \frac{1}{4}$ months of imports) as at end-June 2010, have fallen slightly from the record-high levels reached in March 2010.

8. The Central Bank of Jordan (CBJ) has taken measures to moderate the impact of the slowdown and support domestic credit. A full guarantee of bank deposits has been extended until end-2010; liquidity-withdrawal operations (through CBJ sales of certificates of deposit) ceased in October 2008; and reserve requirements and policy interest rates were cut gradually between November 2008 and February 2010, reducing the interest rate differential against the U.S. Federal Reserve's funds rate from 450 to 200 basis points (Tables 5-6 and Figure 4). Despite these efforts, excess reserves in the banking system-maintained as overnight deposits with the CBJ-increased to almost one quarter of 2009 GDP. Deposit growth has remained healthy, and the share of dinar-denominated deposits has continued to increase. However, in the wake of the global financial crisis, bank credit growth to the private sector slowed to near-zero at end-2009 (see Appendix 1).

\footnotetext{
2 Staff estimates that potential output growth in the period 2009-12 will average about 4 percent per year. It is expected that the recovery of potential output growth in trading-partner countries will raise potential growth in Jordan to about $51 / 2$ percent per year over the medium term.

${ }^{3}$ The Department of Statistics of Jordan has recently made revisions to historical nominal and real GDP numbers for 2008 and 2009. Revised nominal GDP numbers are about 10 percent higher, while real growth has been revised down from 7.8 and 2.8 percent to 7.2 and 2.3 percent, for 2008 and 2009 respectively.
} 


\section{Box 1. Business Cycle Linkages Between Jordan and Major Trading Partners}

\section{Jordan's growth cycle movements are closely linked to those of its regional neighbors and other} large trading partners:

- The Gulf Cooperation Council (GCC) economies (particularly Saudi Arabia) continue to have the most important effect on Jordan's output cycles, as they account for the largest share of Jordanian trade, remittances, grants, FDI, and tourism receipts. In comparison with other oil-importing economies in the region Jordan's output growth has the strongest correlation with the growth in GCC non-oil output.

- In recent years emerging Asian countries have become increasingly important for the Jordanian economy, because of increased trade links (including for mining exports from Jordan). The contemporaneous correlation between Jordan's growth and average growth in China and India for 1990-2009 is about 0.5.

- While correlations with business cycles in Europe and the U.S. have become stronger in the last decade, they are still lower than for other oil importers in the region, particularly Maghreb countries.

\section{Correlations of Output Growth (1990-2009) ${ }^{1}$}
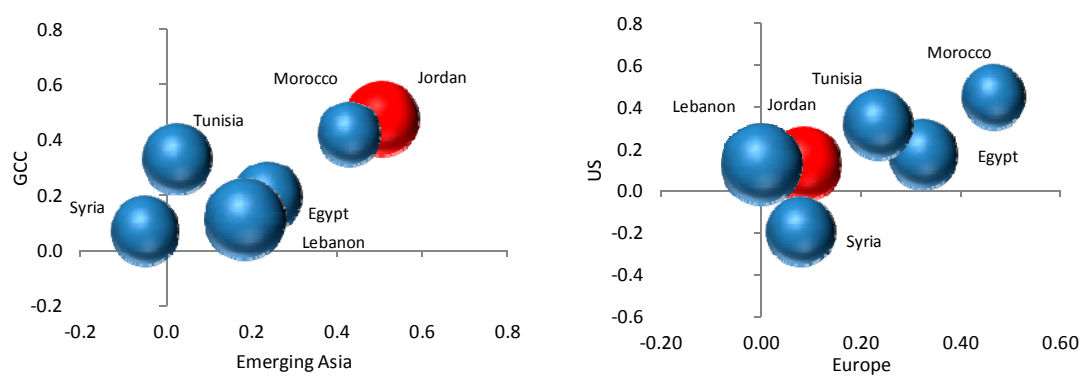

Shocks to the cyclical component of Saudi Arabia's output have a large, long-lasting, and significant impact on Jordan's growth path. An impulse response function projects that a one percentage point (ppt) increase to Saudi Arabian output increases growth in Jordan by about 0.8 ppt. A similar exercise for China suggests an impact of about the same magnitude but it is only short lived. Interestingly, oil price shocks have only a marginal negative effect on Jordan's growth, as they are mitigated by higher FDI, remittances and grants coming from the GCC region.

\section{Responses of Jordan's Output to External Shocks ${ }^{2}$}
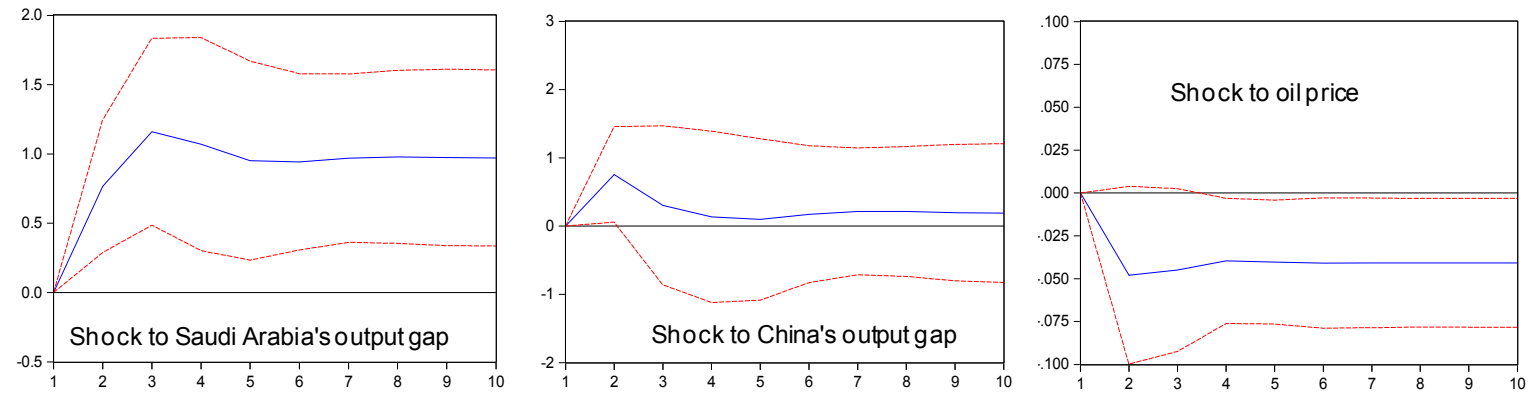

${ }^{1}$ The size of the bubble is equal to the average output growth for 1990-2009. Correlations with GCC economies are based on growth in non-oil GDP.

${ }^{2}$ Output gaps are calculated by applying the ideal band-pass (IBP) filter to annual GDP series. For a detailed description of the IBP, see Paul Cashin and Sam Ouliaris, 2004, "Key Features of Australian Business Cycles," Australian Economic Papers, Vol. 43, pp. 39-58. 


\section{Box 2. Jordan's Economic Recovery}

Jordan's economic recovery from its $\mathbf{2 0 0 9}$ growth downturn has been slow. According to a "heat map" of key economic indicators, economic activity remained below potential in the second half of 2009. Since December 2009, an anemic recovery has been led by rebounding merchandise exports-particularly related to the food, pharmaceuticals, and mining sectors-and construction activities. Demand for imports (excluding food and fuel) and consumer confidence have remained relatively weak, and industrial production has registered a moderate decline in the period January-May 2010.

Jordan: Assessing Growth Momentum, 2009-10

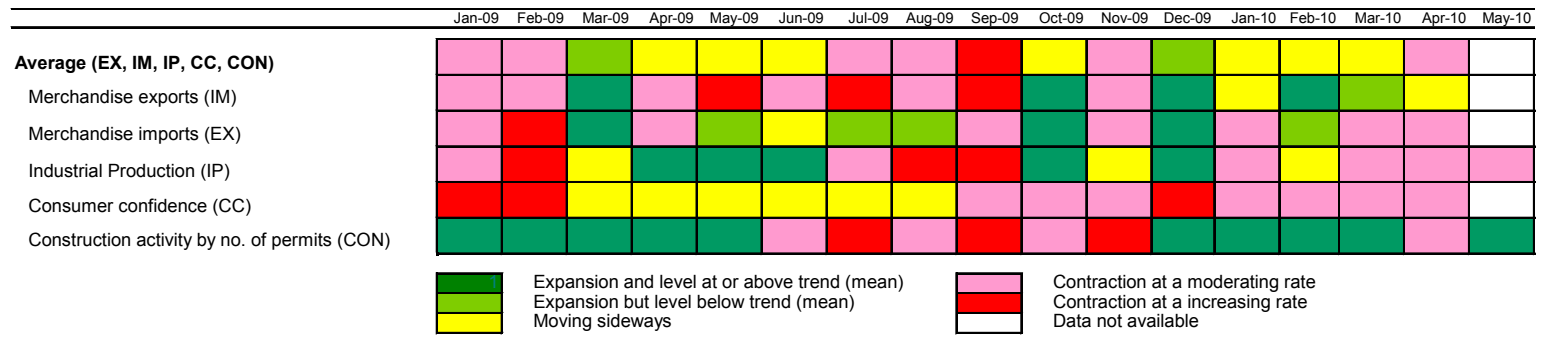

Sources: Jordanian authorities and Bayt.com

1/ For industrial production, exports, imports, and construction activity, observations are based on rate of change of the three-month seasonally adjustment moving averages, while the observations for the consumer confidence index are based on the current month data.

\section{MANAGING THE ECONOMY IN 2010}

9. The near-term policy focus centers on addressing Jordan's underlying fiscal and external vulnerabilities. Given the significant slowdown in external financing and the need to mitigate risks related to Jordan's already-high public debt, fiscal policy focuses on the speed of fiscal consolidation. Monetary policy seeks enhancements to financial sector regulation and the efficacy of monetary measures, to resuscitate credit growth. These broad policy initiatives will help address Jordan's underlying fiscal and external vulnerabilities, while boosting the economy's growth and employment potential.

\section{A. Fiscal Policy: Consolidation Amidst a Cyclical Downturn}

10. To reduce fiscal risks, the $\mathbf{2 0 1 0}$ Budget envisages substantial fiscal consolidation. Based on the latest developments and macroeconomic assumptions, the 2010 overall deficit is expected to narrow by more than 2 percent of GDP relative to the 2009 outturn, reaching about 6 percent of GDP. With lower projected grant receipts and the continued cyclical decline in tax revenues, the consolidation will come mainly from the spending side-involving greater prioritization of capital spending and savings in current expenditures, including from containment of the public sector wage bill and reductions in the operating costs of public institutions and independent

\begin{tabular}{|c|c|c|c|}
\hline \multicolumn{4}{|c|}{$\begin{array}{l}\text { Summary of Fiscal Operations } \\
\text { (In percent of GDP) }\end{array}$} \\
\hline & & Prel. & Proj \\
\hline & 2008 & 2009 & 2010 \\
\hline Total revenue and grants & 29.1 & 25.1 & 23.3 \\
\hline Budgetary revenue, of which: & 24.7 & 23.3 & 21.7 \\
\hline Tax revenue & 17.1 & 16.2 & 14.7 \\
\hline Nontax revenue & 7.5 & 7.1 & 7.0 \\
\hline Grants & 4.5 & 1.9 & 1.6 \\
\hline Total budgetary expenditure & 33.4 & 33.6 & 29.5 \\
\hline Current expenditure, of which: & 27.8 & 25.7 & 24.3 \\
\hline Fuel subsidy & 1.2 & 0.2 & 0.4 \\
\hline Food subsidy & 1.4 & 0.8 & 0.5 \\
\hline Capital expenditure and net lending & 5.6 & 7.8 & 5.2 \\
\hline Statistical discrepancy, net & 1.1 & 0.0 & 0.0 \\
\hline Financing ( = deficit including grants) & 5.4 & 8.5 & 6.2 \\
\hline \multicolumn{4}{|l|}{ Memorandum item: } \\
\hline Overall balance, excluding grants & -9.8 & -10.3 & -7.8 \\
\hline Primary balance excluding grants & -7.5 & -8.1 & -5.5 \\
\hline Structural balance excluding grants & -10.5 & -10.1 & -7.3 \\
\hline Government and guaranteed net debt & 52.9 & 55.8 & 57.3 \\
\hline
\end{tabular}

Sources: Jordanian authorities; and Fund staff projections. 
agencies. Additional revenue measures were introduced in June 2010, including raising indirect taxes on petroleum and other commodities, and reversing the GST exemption for coffee. These measures will partially offset spending additional to those set out in the 2010 budget, on social assistance, commodity subsidies, and teachers' remuneration. Implementation of these fiscal plans would result in a modest uptick in the public debt-to-GDP ratio, which would nonetheless remain below the 60 percent legislated debt ceiling.

11. Policy actions for $\mathbf{2 0 1 0}$ which demonstrate the Government's commitment to fiscal consolidation include: reducing operational costs (particularly transportation costs) of Ministries and autonomous public agencies; cessation of construction of new government buildings, excepting schools and hospitals; and cutting Ministerial salaries by 20 percent. The authorities emphasized that they stand ready to further curtail spending, as necessary, to achieve their fiscal target for 2010 of an overall deficit of about 6 percent of GDP. Indeed, in the first six months of 2010 the overall deficit (excluding grants) fell by almost half vis-à-vis the same period in 2009.

12. The authorities agreed with the mission that there is little room for further countercyclical fiscal policy, given the significant slowdown in external financing and the need to mitigate risks related to Jordan's already-high public debt. In addition, there are downside risks related to implementation of the budget, including emerging spending pressures linked to the forthcoming elections. The mission argued for expeditious elimination of the remaining GST exemptions which were put in place in 2008 in response to the sharp increase in food and fuel prices. The mission also argued that as output growth recovers and comes closer to potential, automatic fiscal stabilizers should be allowed to work so that further fiscal consolidation can occur to help ensure the sustainability of public debt (see Appendix 2). The authorities expected that economic growth would rebound more strongly than projected by the staff, and if that occurred they agreed there would be scope for greater fiscal consolidation than is currently set out in the staff's medium-term projections. The authorities also explained their revised approach to capital spending, whereby a Ministerial Committee prioritizes the allocation of spending within an approved budget allocation-they expected that this process would enable the realization of greater efficiencies in capital spending over the medium term.

13. As output growth recovers and comes closer to potential in 2011-13, further fiscal consolidation should be undertaken. Without substantial consolidation, the fiscal deficit would remain sizable and the public debt-to-GDP ratio would continue to edge up. Fiscal consolidation will also help contain the external current account deficit and free up domestic resources to support private sector-led growth-this can be achieved only by further fiscal adjustment in 2011 and beyond. The mission supports the authorities' policy proposals which (beginning in 2011) would reduce the overall balance by between one-half and one percent of GDP per year (depending on the level of economic activity), and help

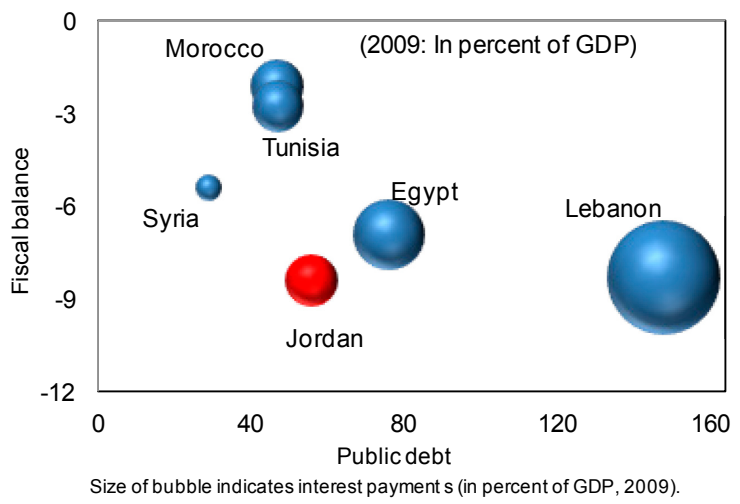
achieve an overall deficit of about 3 percent over the medium term. Priorities underpinning this adjustment include removing remaining tax exemptions on commodities, continuing moderation 
of the wage bill, improving the efficiency of current spending, and ongoing prioritization of capital spending. The authorities preferred to weight consolidation toward expenditure-reduction measures, as they did not want to discourage domestic and foreign investment through higher taxes. The authorities also considered that already-enacted income tax and pension reforms, as well as proposed civil service reforms, would support medium-term fiscal consolidation. In the staff's view, full implementation of the authorities' proposed set of policies would reduce the debt-to-GDP ratio to about 53 percent by 2015 . Such adjustment will be crucial to maintain investor confidence, preserve macroeconomic stability, and create scope for potential future countercyclical fiscal policy.

\section{B. Monetary and Exchange Rate Policy: Resuscitating Private Credit and Maintaining External Competitiveness}

14. A slow-moving recovery in the extension of bank credit is underway. Private sector credit growth turned positive at end-2009, reaching 51/2 percent y-o-y in May 2010. Contributions from credit to construction, tourism, and trade sectors have been increasing since their nadir in September 2009. Following the latest (February 2010) cuts in the policy rate, the accumulation of excess liquidity in the overnight window of the CBJ has reversed. Encouraged by declining interest rate spreads relative to advanced countries, international reserves have stabilized at historically-high levels (see Appendix 3). The Jordanian dinar real effective

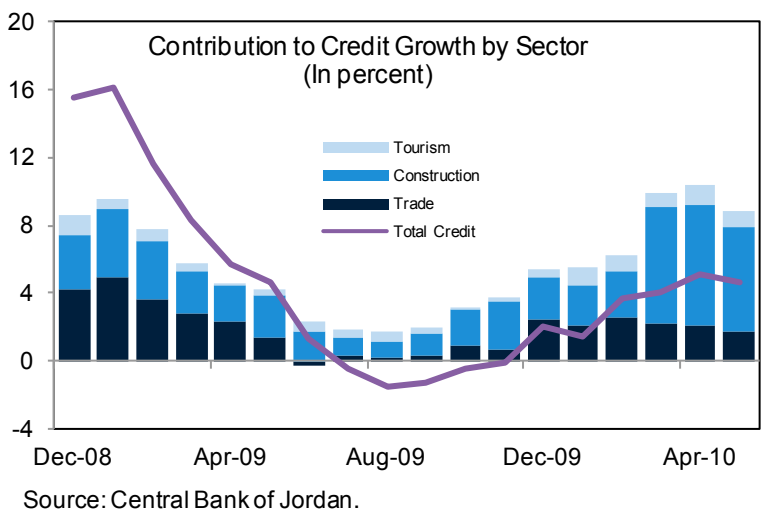
exchange rate has appreciated by $2 \frac{1}{2}$ percent between December 2008 and June 2010, mainly due to the strengthening of the U.S. dollar against major currencies.

\section{While monetary easing in 2009-10 to stimulate domestic demand has been} appropriate, there is likely little room for further monetary stimulus. Since late 2008 , the authorities have taken several prudent steps to sustain confidence and support the domestic financial system. With international reserves large and stabilizing, and given the continuing revival of bank private sector credit, further easing of monetary policy is likely to have a limited policy impact as the interest differential with U.S. rates has fallen to a low level, and inflationary pressures are emerging. The authorities agreed with the staff that imperfect monetary transmission and uncertainty in transmission lags warrant a cautious approach to further policy interest rate changes.

16. The authorities concurred with the staff's recommendation that the CBJ should continue to stand ready to tighten monetary conditions if inflation accelerates or there are signs of pressure on the balance of payments. Recent increases in headline inflation have been largely due to rising international food and energy prices, which are not likely to be driven by excessive domestic demand. However, persistently high headline inflation does risk inducing inflationary momentum through its effect on inflation expectations. Balance of payments pressures could also call for a tightening of monetary policy in support of the international reserve position. Monetary tightening could be implemented by increasing reserve requirements (to reduce excess reserves held at the overnight window), by operations to soak up excess 
banking system liquidity (through resumption of issuance of certificates of deposit), and by raising the policy rate. The authorities also agreed with staff that recent events in Europe had most likely raised sovereign risk premia for all emerging market countries, which would likely be reflected in a widening of Jordanian interest rate spreads over U.S. rates going forward.

17. The exchange rate peg provides an appropriate nominal anchor and remains the key pillar of financial stability. The Jordanian dinar's peg to the U.S. dollar has played an indispensable role in anchoring inflation expectations and providing for financial stability in a volatile region. The authorities agreed with staff's assessment that, although the recent strength of the U.S. dollar has led to some real appreciation of the Jordanian dinar, the real effective exchange rate remains broadly in line with medium-term fundamentals (Box 3 ). They agreed with the staff that the external current account deficit is expected to widen in 2010 as expenditure on imported food and energy commodities rises, and noted that improvements in the recording of capital account transactions (particularly foreign direct investment) had reduced the previouslylarge errors and omissions in the balance of payments. They stated that the exchange rate peg had been crucial in maintaining confidence in the Jordanian economy during the recent period of turmoil in global and regional financial markets.

18. The risk of external instability emanating from the capital account is lowered by the fact that most external debt consists of obligations to official creditors, and reserves far exceed short-term external liabilities. The authorities welcomed the dramatic rise in international reserves in recent years (rising from US $\$ 6.9$ billion at end-2007 to US $\$ 10.4$ billion at end-June 2010), and the ongoing switch from dollar-denominated to dinar-denominated bank deposits, both of which reflect continuing confidence in the peg.

19. The authorities outlined that they plan in the coming months to access substantial external financing, prospectively through a U.S. dollar-denominated Eurobond issuance. The staff urged the authorities to carefully consider opportunities to secure external financing at competitive interest rates and for long tenors, which will reduce near-term rollover needs. Such financing would improve the debt profile, support an accumulation of international reserves, and allow domestic financial resources to be allocated to the private sector. The staff acknowledged the authorities' plans to bolster domestic debt markets through the establishment of sukuk as a source of Islamic financing. Going forward, and following IMF technical assistance, the government is working towards resolving several legal issues which are at present impeding the issuance of sukuk in Jordan.

\section{Financial Sector Policy: Enhancing Regulation of a Robust Banking System}

20. The Jordanian banking system remains sound and has proven resilient to the global financial crisis. The CBJ's prudent banking regulation and supervision, and banks' conservative funding practices (with loan/deposit ratio near 75 percent) have shielded domestic banks from exposure to troubled international banks, structured products, and wholesale financial markets. The banking sector's macroprudential indicators remain strong-banks remain profitable and well capitalized, deposits continue to be the major funding base, liquidity ratios and provisioning remain high, while NPL ratios increased modestly to $62 / 3$ percent of outstanding loans at end-2009 (Table 7; see Appendix 4). However, banks could be exposed to higher non-performing loans and provisioning requirements over the medium term, as Jordan's growth path is likely to remain below potential in the near-term. The authorities acknowledged that while a further near-term deterioration in loan quality may occur, both the CBJ and banks are closely monitoring such exposures and stand ready to take appropriate actions. 


\section{Box 3. Exchange Rate Assessment ${ }^{1}$}

Staff estimates suggest that the real exchange rate of the dinar is broadly in line with medium-term fundamentals. Trajectories of the trade-weighted nominal effective (NEER) and real effective exchange rates (REER) and tourism-based measures of the real exchange rate index ${ }^{2}$ indicate further depreciation-ranging from 3 percent to 6 percent-relative to their end-2008 values.
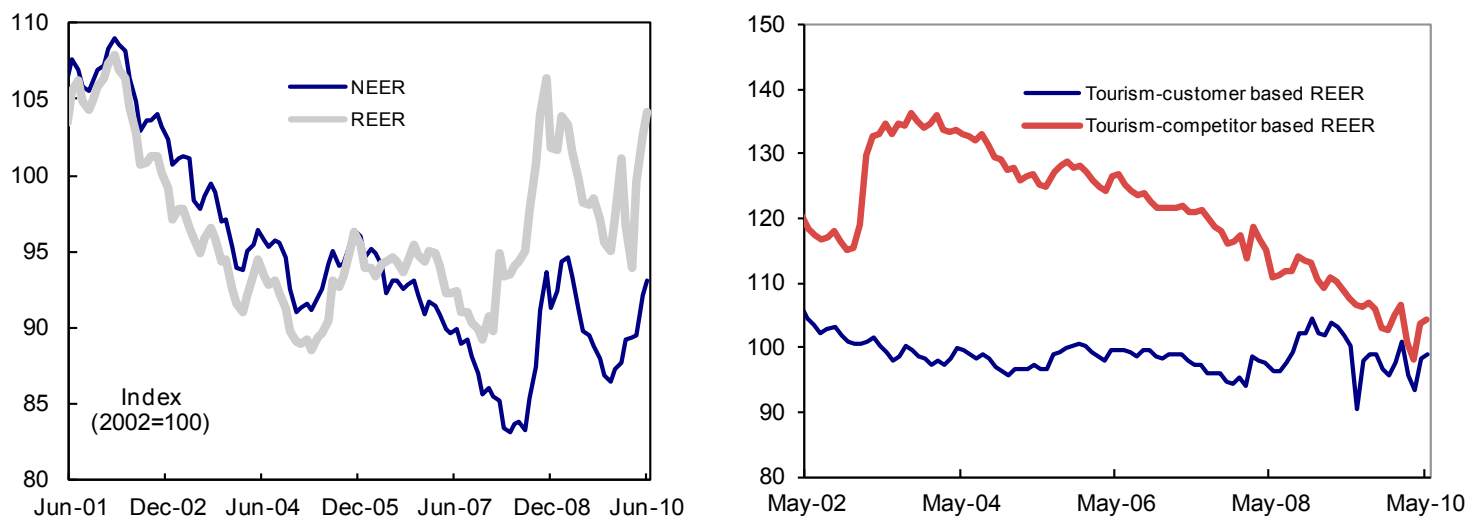

Jordan's robust export performance in recent years also suggests that the country does not face major competitiveness problems. Both goods and services export receipts are estimated to have grown by close to 17 percent on average over the past five years (2005-09). Among services exports, the important tourism receipts, which accounts for one quarter of exports of goods and services, has been particularly dynamic in 2009 and thus far in 2010, as reflected in significantly higher tourist arrival numbers.

Estimates from the IMFs' three Consultative Group on Exchange Rate (CGER)-based methodologies for exchange rate evaluation indicate modest overvaluation (the macroeconomic balance, equilibrium real exchange rate and external sustainability approaches point to a somewhat overvalued exchange rate in the medium term (between 1 and 13 percent)). On average, there is little indication of a marked misalignment of the Jordanian dinar's real effective exchange rate for the medium term (2015), with the actual REER calculated as overvalued by less than 7 percent vis-à-vis the equilibrium REER.

Jordan: Assessment of the Real Effective Exchange Rate

\begin{tabular}{|c|c|c|c|}
\hline $\begin{array}{l}\text { I. Macroeconomic } \\
\text { balance } 1 /\end{array}$ & II. External sustainability 2/ & $\begin{array}{l}\text { III. Equilibrium real } \\
\text { exchange rate } 3 /\end{array}$ & Average misalignment $\square$ \\
\hline $\begin{array}{cc}2009 & 2015 \\
\text { fundamentals } & \text { fundamentals }\end{array}$ & $\begin{array}{cc}2009 & 2015 \\
\text { fundamentals } & \text { fundamentals }\end{array}$ & $\begin{array}{cc}2009 & 2015 \\
\text { fundamentals } & \text { fundamentals }\end{array}$ & $\begin{array}{cc}2009 & 2015 \\
\text { fundamentals } & \text { fundamentals }\end{array}$ \\
\hline
\end{tabular}

[Misalignment as percentage deviation from estimated equilibrium, overvaluation (+), undervaluation (-)].
7.1
12.9
5.1
0.7
$-10.2$
6.7
0.7
6.7

$1 /$ Measures the adjustment needed to eliminate the gap between an estimated current account "norm"—obtained from applying CGER cross-country panel regression coefficients to Jordanian data-and the projected "underlying" medium-term current account balance for Jordan.

2/ Provides an estimate of the adjustment needed to stabilize Jordan's net foreign assets (NFA) to GDP ratio at its end-2008 level (-92 percent of GDP), using CBJ data for NFA.

$3 /$ Estimates the deviation between the actual and the "equilibrium" REERs. The latter is obtained by applying coefficients from the CGER cross-country panel regression to Jordanian data.

\footnotetext{
${ }^{1}$ For a description of the methodology underlying these updated estimates of exchange rate misalignment, see Chapters I and II, respectively, of the Selected Issues paper for the 2008 Article IV Consultation (IMF Country Report No. 08/291).

${ }^{2}$ Following the methodology of Emilio Pineda, Paul Cashin, and Yan Sun, 2009, "Assessing Exchange Rate Competitiveness in the Eastern Caribbean Currency Union," IMF Working Paper 09/78, the real effective exchange rate is measured against the currencies of Jordan's major customers and major regional competitors in the tourism sector.
} 


\section{Box 3. Exchange Rate Assessment (concluded)}

\section{Estimates from alternative exchange rate evaluation} methodologies ${ }^{3}$-based on a developing country-specific (including Middle East countries) version of the CGER macroeconomic balance approach to the current account-indicate that while Jordanian current account imbalances have exhibited large fluctuations over time, these have narrowed since 2007, pointing to a current account position close to the current account norm.

\section{Using the macroeconomic} balance approach, Fund staff estimate Jordan's equilibrium current account deficit under current policies (the current account 'norm') at around 8 percent of GDP. Jordan's projected medium-term (2015) deficit of $71 / 4$ percent of GDP is within one standard error of the estimated current account norm. This implies that the medium-term current account imbalance-largely financed by private capital flows (particularly FDI)-appears sustainable, and is in line with the equilibrium level predicted by fundamentals. Accordingly, as with the standard CGER approaches, there is little evidence of real exchange rate misalignment, as the medium-term current account balance is close to the current account norm.
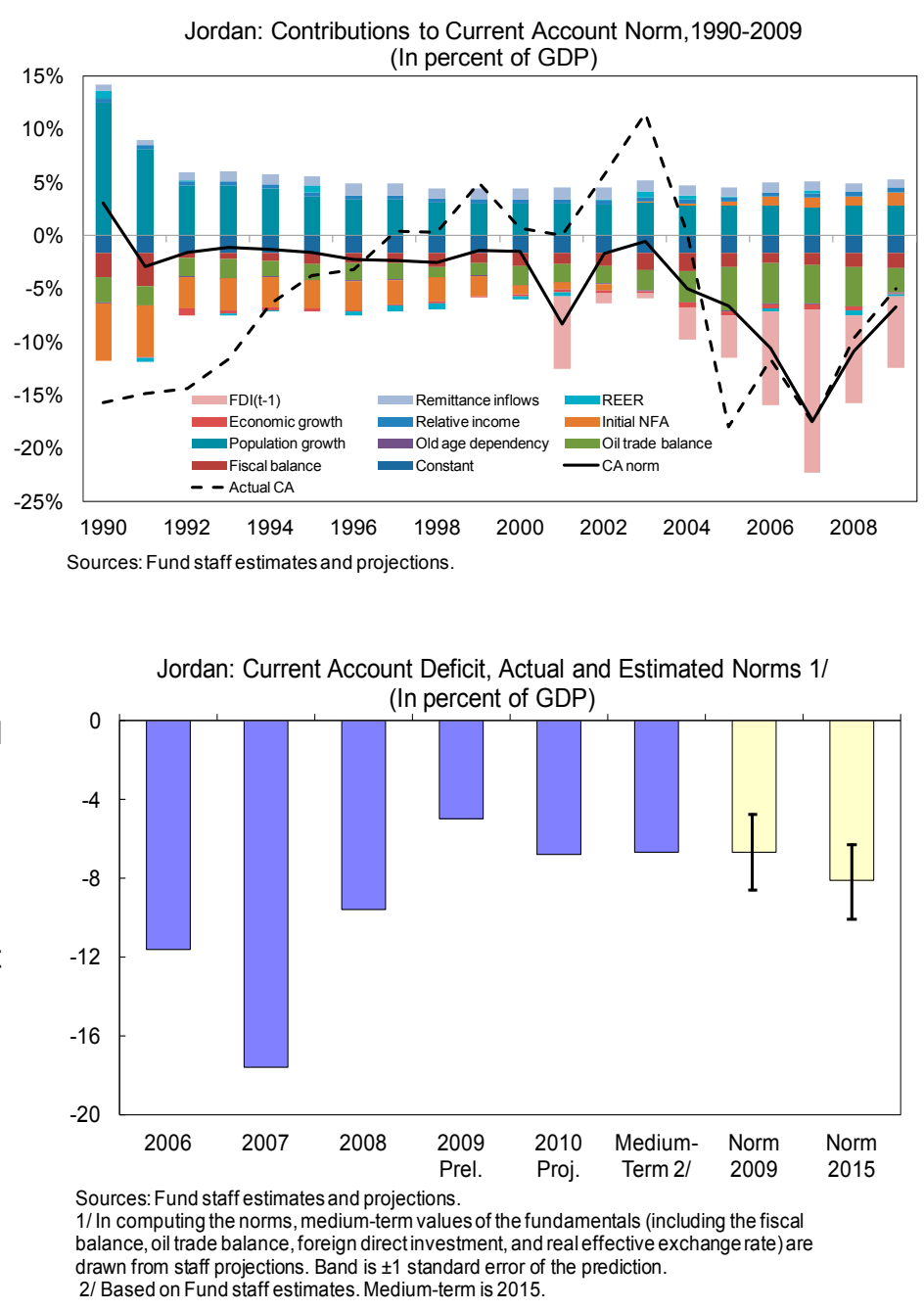

\footnotetext{
${ }^{3}$ Following the methodology of Samya Beidas-Strom and Paul Cashin, forthcoming, "Are Middle Eastern Current Account Imbalances Excessive?," which estimates Middle Eastern current account norms using augmented fundamental determinants of the macroeconomic balance approach of the IMF's CGER relevant to three subgroups of developing economies (oil exporters, oil importers and low-income countries).
} 
Jordan: Indicators of Bank Soundness, 2003-2009

\begin{tabular}{lrrrrrrr}
\hline & 2003 & 2004 & 2005 & 2006 & 2007 & 2008 & 2009 \\
\hline & \multicolumn{7}{c}{ (In percent, unless otherwise indicated) } \\
Risk-weighted capital adequacy ratio & 15.9 & 17.8 & 17.6 & 21.4 & 20.8 & 18.4 & 19.6 \\
Non-performing loans (in millions of JD) & 716 & 581 & 481 & 405 & 453 & 550 & 877 \\
Non-performing loans (in percent of total loans) & 15.5 & 10.3 & 6.6 & 4.3 & 4.1 & 4.2 & 6.7 \\
Provisions (in percent of classified loans) & 51.9 & 63.8 & 78.4 & 80.0 & 67.8 & 63.4 & 51.9 \\
Liquidity ratio & 179.6 & 173.0 & 168.0 & 161.4 & 157.5 & 141.2 & 159.1 \\
Return on assets & 0.7 & 1.1 & 2.0 & 1.7 & 1.6 & 1.4 & 1.1 \\
Return on equity & 9.9 & 13.1 & 20.9 & 15.0 & 12.6 & 11.5 & 8.8 \\
\hline
\end{tabular}

Source: Central Bank of Jordan.

\section{Effective banking supervision has strengthened the capacity of Jordanian banks}

to withstand shocks. The mission welcomes measures taken by the CBJ to further enhance its effective banking regulation and supervision, including: (i) introduction of Basle II (Pillars I and III) regulations in 2008, and ongoing efforts to ensure compliance of banks with Pillar II guidelines for risk management (issued in February 2010); (ii) requiring semi-annual stress testing of banks (issued in September 2009), examining in particular credit risk and concentration risk, with aggregated results reported transparently in the CBJ's Financial Stability Report; (iii) introduction of an automated data collection system, to improve off-site monitoring of banks (June 2010); (iv) enhanced cross-border bank regulation through regular supervision and on-site inspections of international branches and subsidiaries of Jordanian banks; and (v) improvements to its early warning system. IMF technical assistance has provided further support and training in Basle II implementation (July 2010). In addition, the authorities passed the law establishing a private credit bureau (June 2010), which will be supervised by the CBJ and should promote bank and non-bank private credit flows. The authorities noted that they continue to take steps to guard against risks in the banking system, and concurred with the staff that they have implemented many of the recommendations contained in the FSAP Update (Appendix 5).

\section{The authorities have recently strengthened their Anti Money} Laundering/Combating the Financing of Terrorism (AML/CFT) framework. Jordan is working towards strengthening its AML/CFT system according to the standards of the Financial Action Task Force (FATF). Major components of this strengthening involved: amending the anti-money laundering law in May 2010; issuing regulations that grant the Financial Intelligence Unit greater independence; the adoption of AML/CFT inspection manuals by the CBJ and the Insurance Commission; and instituting a cash declaration system at the borders in March 2010.

\section{The Medium-Term OUtLOOK}

23. Over the medium term, macroeconomic stability will continue to hinge upon a prudent fiscal policy. Output growth is expected to pick up in line with the global and regional recovery, with the output gap expected to close by 2012. Core inflation is projected to remain low. Rebounding demand for imports and still-high commodity prices will result in a modest widening of the current account deficit to around 81/3 percent of GDP by 2011, with a recovery of activity in trading partners and associated increase in exports narrowing the deficit to about 7 percent of GDP by 2015 . However, without substantial fiscal consolidation the fiscal deficit will remain sizable and the public debt-to-GDP ratio will continue to edge up (Appendix 6). Main risks 
are the continued fluctuations in international oil prices and external grants, with their consequent impacts on the fiscal and external accounts (Appendix 7).

\section{A key medium-term policy goal is to reduce fiscal and external vulnerabilities while achieving higher economic growth and employment.}

- $\quad$ Progress in structural reforms is a major policy goal to reduce fiscal and external vulnerabilities, while achieving higher economic growth and employment over the medium term. Further improving the business environment for the private sector should help raise productivity and reinforce Jordan's competitiveness. In this connection, the mission acknowledged progress in implementing reforms-in early 2010 the Jordanian Cabinet passed legislation that lowers the average tax burden, and enhances the investment climate. The mission noted that these are steps in the right direction and need to be supported by additional reforms to further improve the business climate to attract private investment and enhance future competitiveness. In May 2010, the authorities reformed the social security system to improve the sustainability and actuarial soundness of their pension scheme. In addition, the revised social security law introduces unemployment insurance to social security recipients, which should enhance labor market flexibility (commencing July 2011). The mission recommended that other structural reform priorities should include further liberalization of the water and energy sectors, and completion of civil service reforms (which the authorities are embarking upon with technical assistance from the World Bank and USAID).

- $\quad$ Greater openness to trade in goods and services, along with reduction in the cost of public services, will raise the rate of growth of potential output. The authorities are close to completing their National Trade Strategy for 2011-15, which will guide their export and import initiatives over the medium term; Jordan is also negotiating with Mercosur countries in seeking to establish a free trade agreement. The tourism sector has performed extremely well in 2009-10, with tourist arrivals and tourism receipts increasing by about 30 percent in the first half of 2010 vis-à-vis the same period in 2009. Going forward, continued training of local labor and reductions in the cost of key inputs (power and water) will be essential to attract foreign direct investment and boost tourism capacity.

- With a sound institutional framework in place to control for fiscal risks, public-private partnerships (PPPs) can provide a useful vehicle to address infrastructure bottlenecks in a tight fiscal environment. The authorities have an ambitious program of large-scale infrastructure development, particularly in the provision of power, water, and rail transportation infrastructure, to be financed by PPPs. While PPPs can offer better value for money in the provision of public infrastructure, international experience has demonstrated that they can also generate potential fiscal liabilities. The mission recommends that a number of preconditions be put in place, including improving existing PPP regulations to approve a legal framework that ensures adequate risk transfer to the private sector and prescribes a clear process for the evaluation and approval of PPPs. Other elements of a sound PPP framework would include competitive bidding procedures, capacity-building at the government level, and proper accounting and reporting of fiscal implications. The authorities stated that they are currently in the process of strengthening an earlier framework law for PPPs, which will be submitted to Cabinet later in 2010. 
- $\quad$ Fiscal institutions should continue to be strengthened. Progress in public sector structural reforms is critical to enhance the business environment for private sector-led growth. The mission recommended that accelerated steps be taken to improve public sector financial management through: further strengthening the medium-term framework for budget formation and implementation; introducing the Government Financial Management Information System across government ministries; and improving cash management through full implementation of the Treasury Single Account. In addition, as the number of autonomous public agencies had increased to 61 by end-2009, structural reform of overall public expenditure policies will be needed to reduce the burden of government entities on the budget. The authorities broadly agreed with the staff's recommendation on reducing the number of autonomous agencies, and are moving to merge several agencies to reap cost savings and efficiency gains, in the context of ongoing civil service reforms.

- $\quad$ Given Jordan's large stock of public debt, formation and communication of the government's debt reduction and debt management strategy will be critical. The authorities have taken steps to enhance the efficiency of debt issuance by increasing the number of Treasury bill and bond auctions and reducing the size of offers, and by moving toward the establishment of a debt auction calendar. Going forward-in line with IMF technical assistance recommendations-the government should accelerate its efforts to: formulate and communicate a medium-term debt management strategy; establish a robust middle-office function within the Ministry of Finance's Public Debt Department; and enhance the primary and secondary market for government securities.

25. Further improvements in economic statistics will support the quality of policy formation and economic monitoring. Substantial progress in improving data quality and coverage - particularly for budget revenues and expenditures-led to Jordan's subscription to the Fund's Special Data Dissemination Standard (SDDS) in January 2010. The mission welcomed the finalization of SDDS subscription, as well as recent revisions to the historical balance of payments statistics which better accounted for FDI flows and thereby reduced the size of errors and omissions. The mission supports the authorities' plans to seek follow-up technical assistance on improvements to its balance of payments statistics. Further enhancements in the frequency and timeliness of expenditure-based national accounts data, and in the quality of high-frequency production-based national accounts, would assist policy formulation. The development of regular and timely wage, employment and real estate statistics would also enhance monitoring of labor and asset markets.

\section{A joint CBJ-IMF research workshop was held at the conclusion of the Article IV} consultation. The main themes of the research workshop included: presentation of MCD's Regional Economic Outlook for the Middle East; determinants of the Jordanian business cycle (Box 1); analysis of the slowdown in credit flows (Appendix 1); and development of a financial conditions index (Figure 4) and general equilibrium model for Jordan (Appendix 7). The authorities were pleased with the structure and content of the workshop, and requested that this exercise be repeated during future Article IV consultations. 


\section{StAFF Appraisal}

27. Following a decade of strong growth, the Jordanian economy has slowed, largely due to the global and regional downturn. Economic activity is expected to pick up modestly in 2010, and accelerate further over the medium-term, as growth revives in key regional trading partners, bringing Jordanian output closer to potential.

28. The authorities have implemented prudent fiscal and monetary policies, which have ensured fiscal sustainability and supported the domestic financial system. Even in the presence of a cyclical downturn in economic activity, the government has proceeded with its fiscal consolidation plans for 2010 and the medium term. Fully implemented, this should contribute to a significant reduction in the debt-to-GDP ratio, and provide for a major amelioration of fiscal vulnerabilities. Similarly, the monetary authorities implemented cautious monetary easing in the period between late-2008 and early-2010, in an effort to raise private sector credit flows, and also took the opportunity provided by abundant capital inflows to bolster international reserves.

29. In view of the shortfall in external grants and the authorities' desire to signal to markets their seriousness in ensuring fiscal sustainability, the staff supports the fiscal consolidation envisaged in the 2010 Budget. Staff believes that the decline in the overall deficit of about 2 percent of GDP this year is both appropriate and achievable, and would leave fiscal room for an envisaged increase in social expenditures, while maintaining sizeable capital expenditures. While implementation of these fiscal plans would result in a small rise in the public debt-to-GDP ratio in 2010, it would still remain below the 60 percent legislated debt ceiling.

30. The authorities' objective of reducing the fiscal deficit to about 3 percent of GDP over the medium term is critical to achieving private sector-led growth and reducing vulnerabilities. Reducing the overall deficit by about 3 percent of GDP over the next five years is feasible, based on the experience of other countries, and would lead to a further 5 percentage point decline in Jordan's debt-to-GDP ratio. Such adjustment will be crucial to maintain investor confidence, preserve macroeconomic stability, and create scope for future countercyclical fiscal policy. Efficiency gains in both revenue-raising and expenditure will help durably address Jordan's main fiscal vulnerabilities. Priorities include removing remaining tax exemptions on commodities, ongoing prioritization of capital spending, and continued moderation of growth in the public sector wage bill.

31. Significant progress has been made in advancing structural reforms, yet the Jordanian authorities continue to face a number of policy challenges. In the near-term, further improvement in the business environment for the private sector will be key to raising productivity and building upon Jordan's external competitiveness. Staff supports the recent enhancements to income taxation and investment policy, and recommends that additional reform priorities include further liberalization of important business inputs (particularly energy and water sectors), as well as the achievement of greater public sector efficiencies through implementation of civil service reforms.

32. The medium-term fiscal strategy should be supported by a number of institutional reforms. These include strengthening tax administration and reenergizing the implementation of public sector financial management reforms. In an effort to relieve infrastructure bottlenecks, the authorities plan an ambitious medium-term program of large-scale infrastructure development, to 
be largely financed by public-private partnerships (PPPs). As an important prior action, the staff recommends that a strong framework needs to be put in place to minimize the risk of contingent liabilities stemming from PPPs.

33. Monetary policy has rightly focused on monetary easing in 2009-10 to stimulate domestic demand, yet there should now be a pause on further monetary stimulus. Since late 2008 the authorities have taken several steps to support the domestic financial system, including multiple reductions in the policy rate and cessation of issuance of certificate of deposits. Jordan's current stock of international reserves is large and stable, and given the growing turnaround in private sector credit flows and some evidence of emerging inflationary pressures, the staff recommends that the monetary authorities stand ready to tighten monetary conditions as appropriate.

34. The fixed exchange rate regime remains important for financial stability. The Jordanian dinar's peg to the U.S. dollar has acted as an appropriate nominal anchor for the economy. Analysis by the staff of the real effective exchange rate indicates that the dinar remains broadly aligned with its medium-term fundamentals. In addition, the risk of external instability emanating from the capital account is lowered by the fact that most external debt consists of obligations to official creditors, and reserves far exceed short-term external liabilities.

35. Bank regulation and supervision should continue to focus on preventing

excessive risk taking. The banks' conservative funding and asset structures, underpinned by effective banking supervision and regulation, have limited exposures to adverse global liquidity conditions. As a consequence, the banking sector's macroprudential indicators remain strong. Nonetheless, bank supervision and regulation should remain vigilant, as Jordanian banks could be exposed to higher non-performing loans and provision requirements in the coming years, as output growth is likely to remain below trend until 2012.

36. Given Jordan's large stock of debt, it will be important to have clear, timely and proactive communication of policy intentions for debt reduction and debt management, in large part to build ownership for necessary fiscal reforms. Communication of the government's medium-term debt management strategy will be particularly relevant, as will enhancements to the primary and secondary markets for public debt.

37. While substantial progress in improving data quality and coverage has occurred in recent years, the statistical system needs to be further improved. Jordan is to be congratulated for its January 2010 subscription to the IMF's Special Data Dissemination Standard. Nonetheless, data inadequacies persist, particularly in the areas of the expenditure side of the national accounts, and in employment and wage statistics, which continue to hamper economic analysis and policy formation. The staff urges greater progress in resolving these inadequacies.

38. It is proposed that the next Article IV consultation be held on the standard 12-month cycle. 
Figure 1. Jordan: Real Sector Developments and Outlook

Output growth fell in 2009 and...

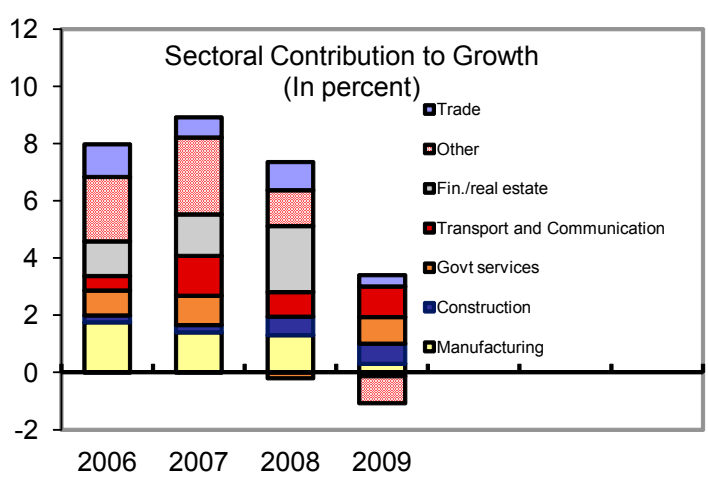

While core inflation remained stable, headline inflation followed movements in world commodity prices...

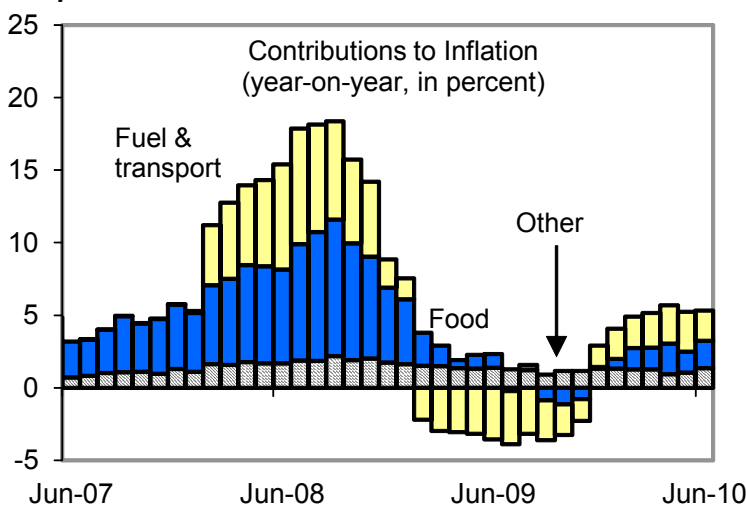

Growth in construction activity has faltered, and industrial production remains below trend.

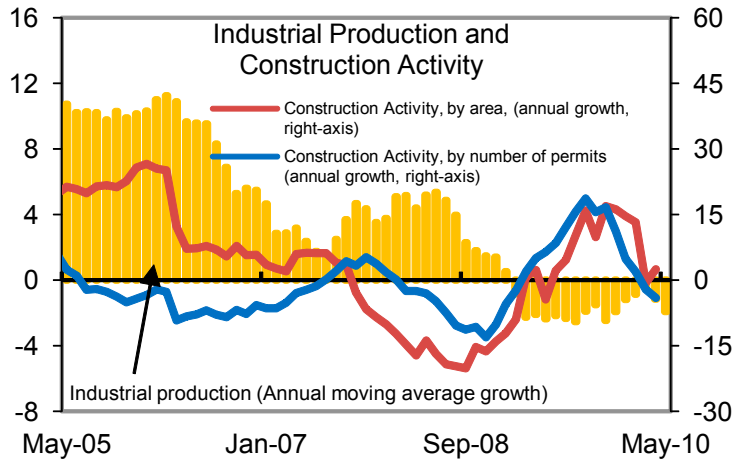

...is expected to remain below trend in 2010.

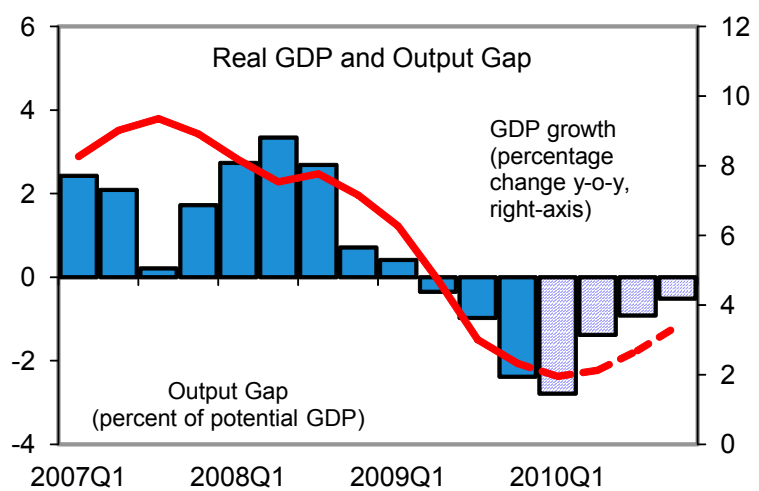

...which are expected to rise in the near term.

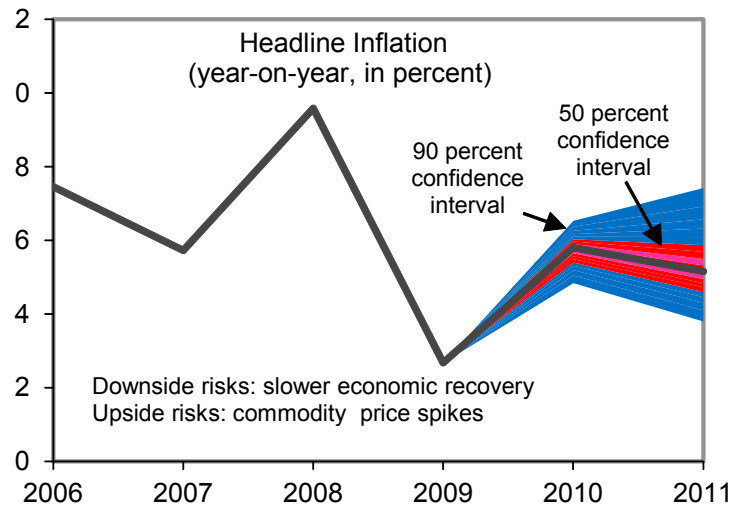

Unemployment edged up in 2009, and is expected to remain high in 2010.

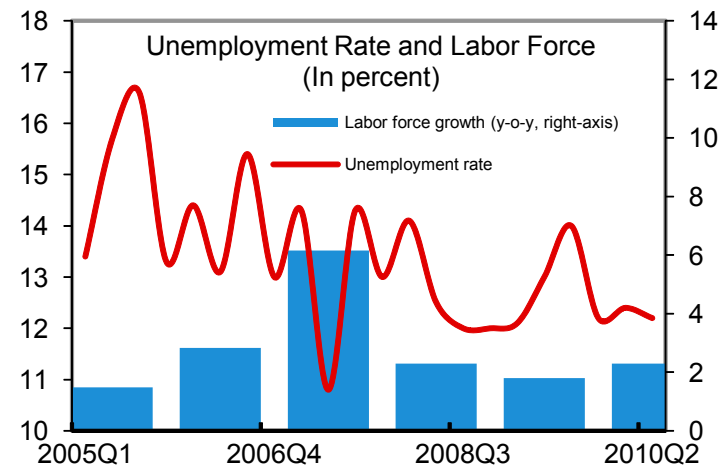

Sources: Jordanian authorities; and Fund staff projections. 
Figure 2. Jordan: Fiscal Developments

(In percent of GDP, unless otherwise noted)

Domestic revenue softened and external grants fell in 2009...

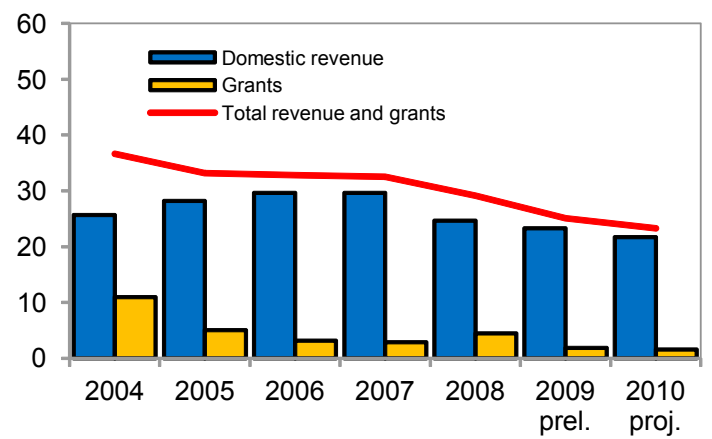

The overall deficit widened in 2009. However, the structural deficit excluding grants declined and is expected to narrow further in 2010.

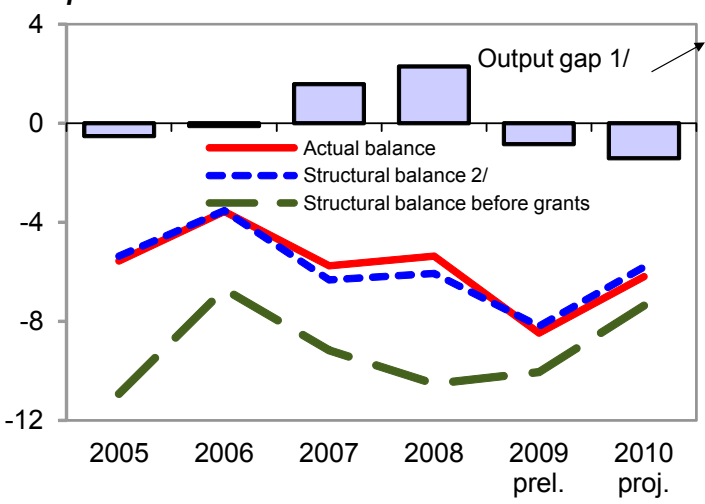

Interest expenditure remains sizable, and is expected to increase in 2010.

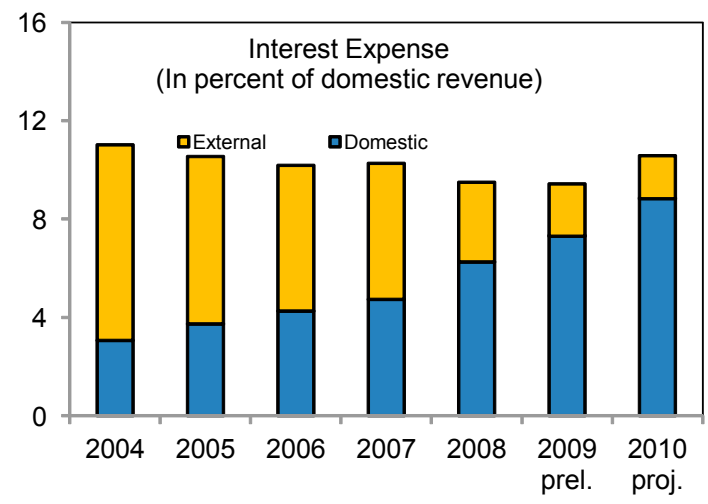

...while spending remained broadly unchanged due to the lower cost of subsidies.

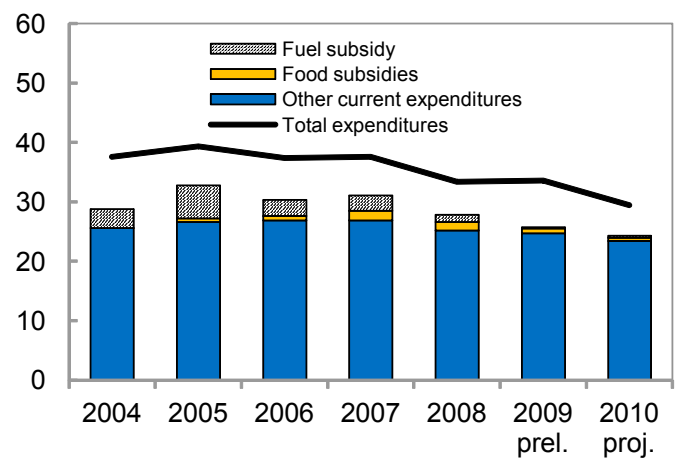

The public debt ratio edged up in 2009, with the share of domestic debt increasing.

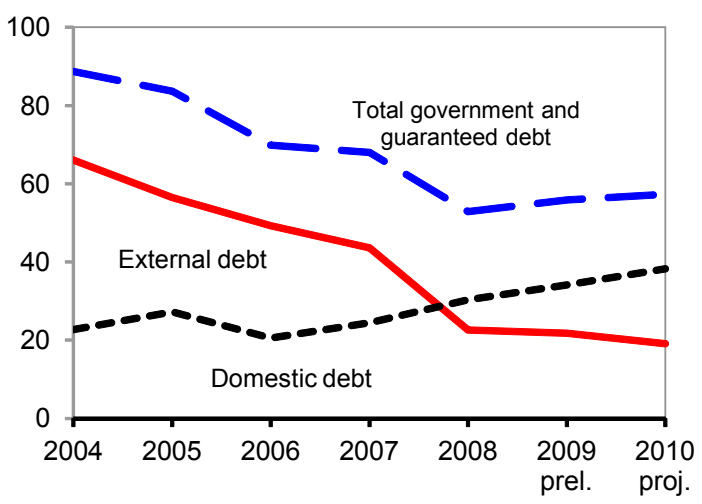

Public debt is projected to remain below its medium-term ceiling (60 percent of GDP) with more risks on the upside.

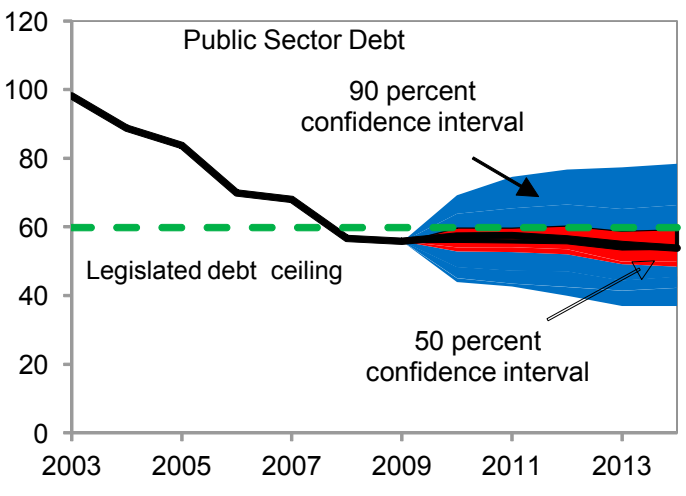

Sources: Jordanian authorities; and Fund staff projections.

$1 /$ The output gap is actual output less potential output, as a percent of potential output.

2/ Structural balance is expressed as a percent of potential output. The structural balance is the budgetary position (overall balance) that would be observed if the level of actual output coincided with potential output. 
Figure 3. Jordan: External Sector Developments

Remittances and tourism receipts remained strong in 2009 ...

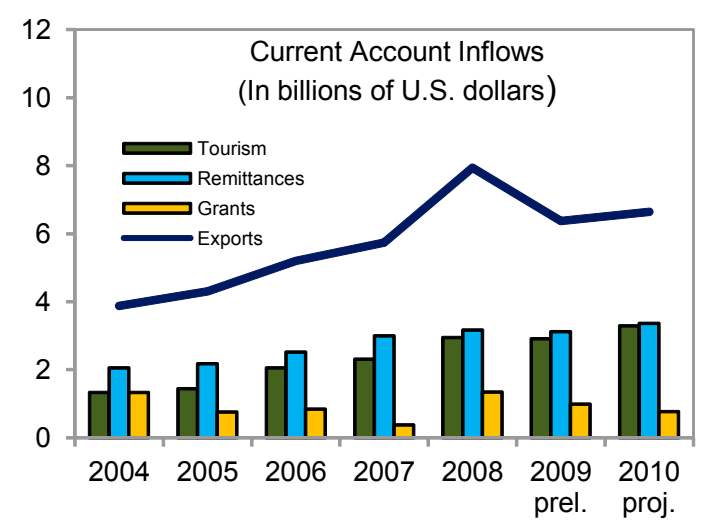

Imports, mainly commodity related, have also declined.

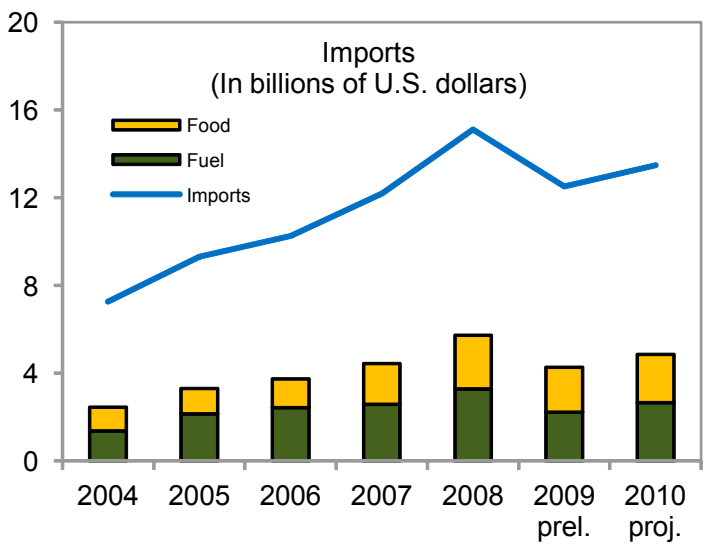

International reserves have stablized at a high level.

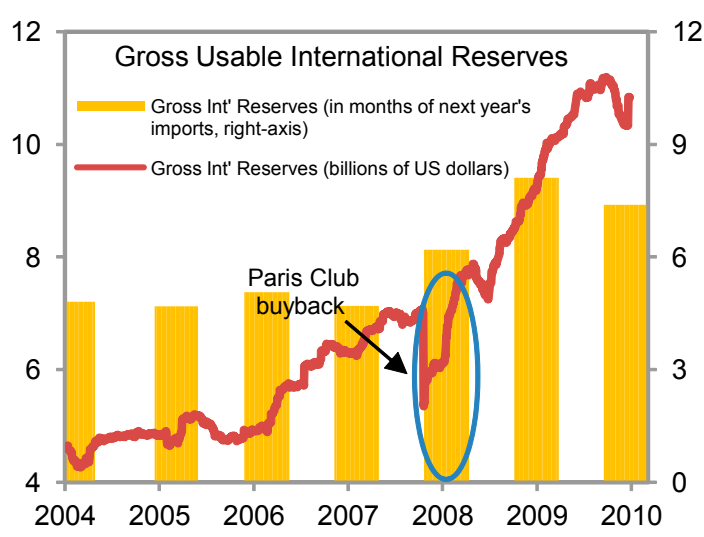

...while exports, particularly mining exports to emerging markets, moderated.

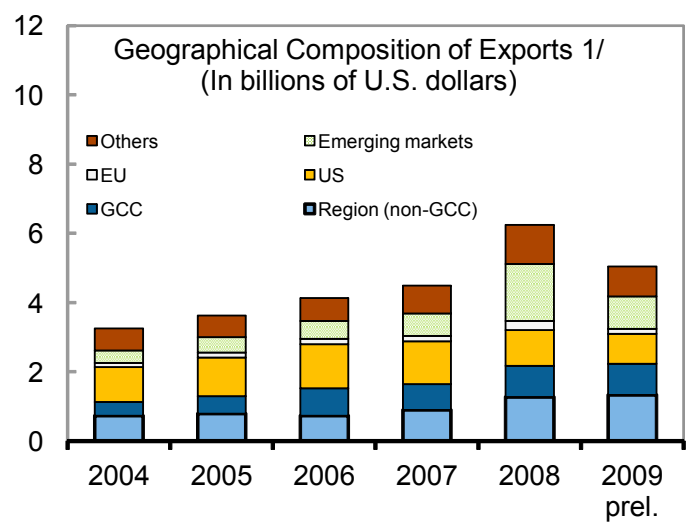

As a result, the current account deficit has narrowed in 2009.

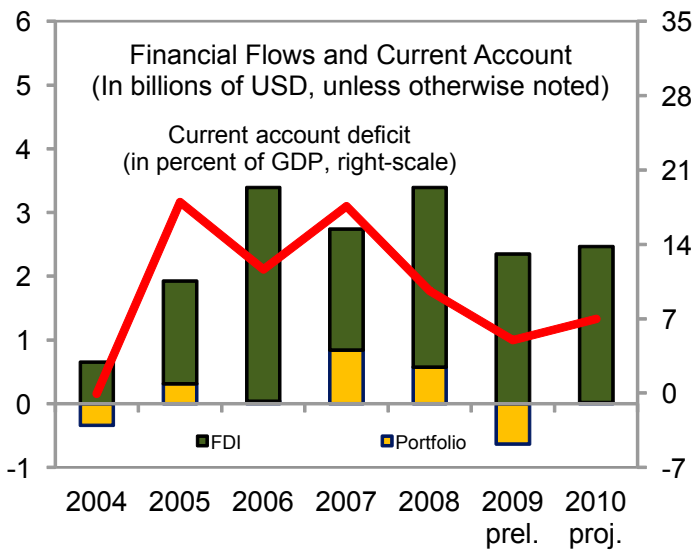

External debt remains low compared to other countries in the region.

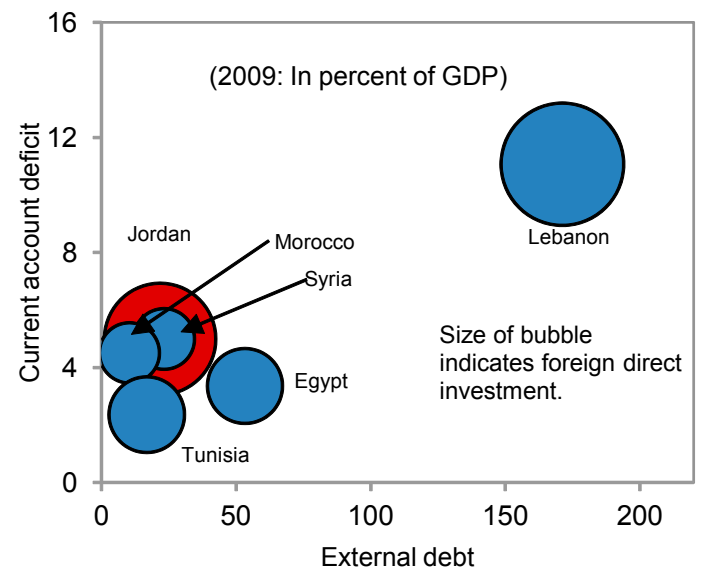

Sources: Jordanian authorities; and Fund staff projections.

1/ Region includes: Egypt, Lebanon, Iraq, and Syria.

Emerging markets includes: China, India, Indonesia, Malaysia, and Turkey. 
Figure 4. Jordan: Monetary and Financial Indicators

Policy interest rates have been lowered in several steps since November 2008.

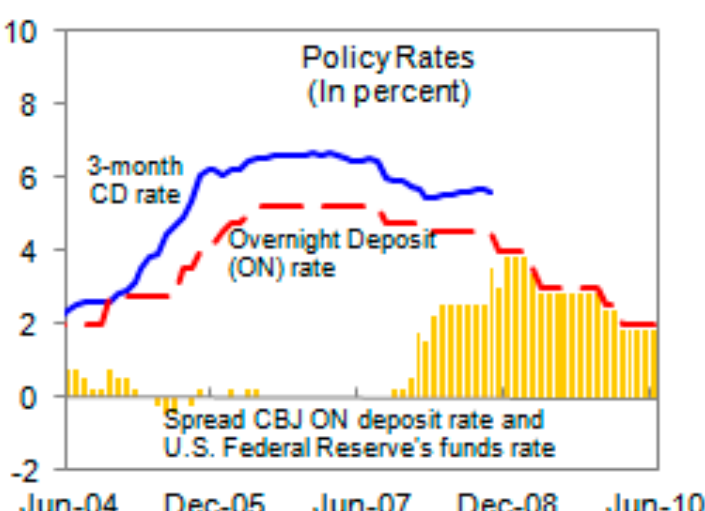

Following the cessation of $C D$ issuance in November 2008, excess liquidity remains high.

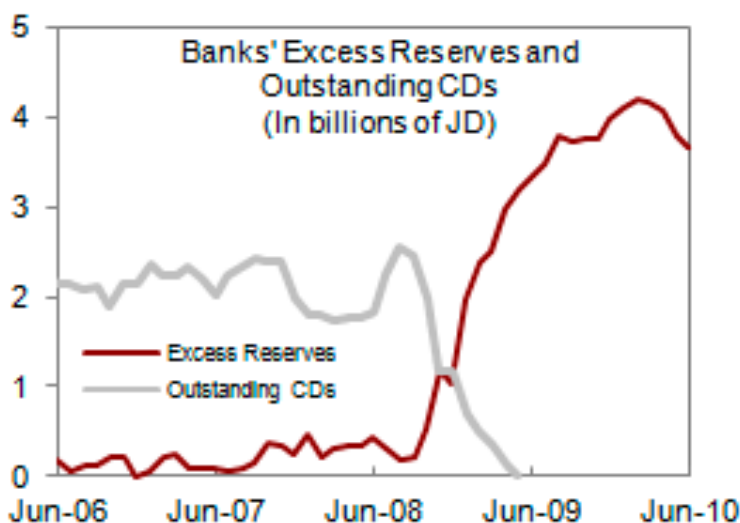

Private sector credit growth is slowly rebounding after a sharp decline through Q3 2009...

...although commercial lending rates remain high, reflecting repricing of bank credit risks.
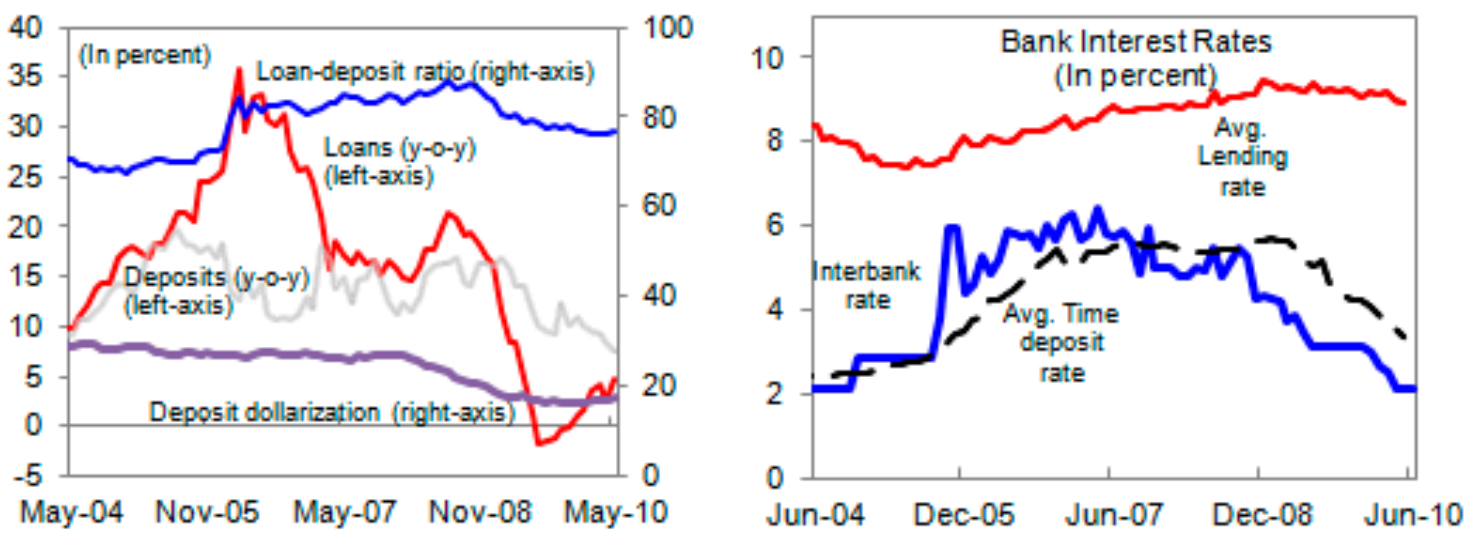

The Amman Stock Exchange performance has been anemic...
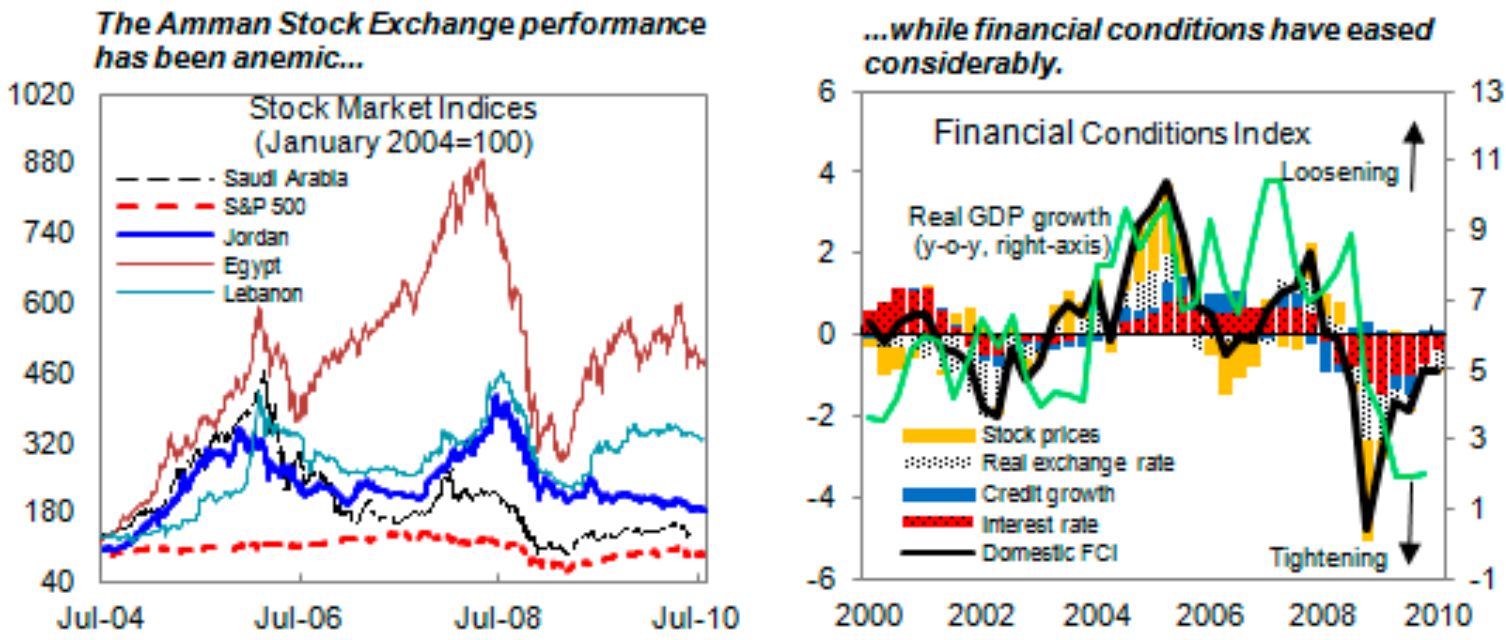

Sources: Jordanian authorities; and Fund staff projections. 
Table 1. Jordan: Selected Economic Indicators and Macroeconomic Outlook, 2006-15

\begin{tabular}{|c|c|c|c|c|c|c|c|c|c|c|}
\hline & \multirow[b]{2}{*}{2006} & \multirow[b]{2}{*}{2007} & \multirow[b]{2}{*}{2008} & \multirow{2}{*}{$\frac{\text { Prel. }}{2009}$} & \multicolumn{6}{|c|}{ Projections } \\
\hline & & & & & 2010 & 2011 & 2012 & 2013 & 2014 & 2015 \\
\hline Output and prices & \multicolumn{10}{|c|}{ (Percentage change, unless otherwise indicated) } \\
\hline Real GDP at market prices & 8.0 & 8.9 & 7.2 & 2.3 & 3.4 & 4.2 & 5.0 & 5.5 & 5.5 & 5.5 \\
\hline GDP deflator at market prices & 8.8 & 5.2 & 24.7 & 8.1 & 4.7 & 5.0 & 4.2 & 3.5 & 2.5 & 2.2 \\
\hline Nominal GDP at market prices & 17.5 & 14.6 & 33.6 & 10.6 & 8.2 & 9.4 & 9.4 & 9.2 & 8.1 & 7.9 \\
\hline Nominal GDP at market prices (JD millions) & 10,521 & 12,057 & 16,108 & 17,816 & 19,284 & 21,100 & 23,083 & 25,211 & 27,252 & 29,396 \\
\hline Nominal GDP at market prices ( $\$$ millions) & 14,839 & 17,005 & 22,706 & 25,113 & 27,175 & 29,752 & 32,547 & 35,547 & 38,425 & 41,448 \\
\hline Consumer price index (annual average) & 6.3 & 5.4 & 14.9 & -0.7 & 5.7 & 5.0 & 4.2 & 3.5 & 2.5 & 2.2 \\
\hline Consumer price index (end of period) & 7.5 & 5.7 & 9.6 & 2.7 & 5.8 & 5.2 & 3.6 & 2.5 & 2.2 & 2.2 \\
\hline Unemployment rate (percent) & 14.1 & 13.1 & 12.7 & 13.0 & $\cdots$ & $\ldots$ & $\ldots$ & $\cdots$ & $\ldots$ & $\ldots$ \\
\hline Investment and savings & \multicolumn{10}{|c|}{ (In percent of GDP, unless otherwise indicated) } \\
\hline Consumption & 103.5 & 106.7 & 104.6 & 98.2 & 100.2 & 99.3 & 98.7 & 98.0 & 97.2 & 96.4 \\
\hline Government & 19.3 & 22.8 & 22.9 & 21.5 & 18.8 & 18.4 & 17.9 & 17.5 & 17.1 & 16.7 \\
\hline Other & 84.2 & 83.9 & 81.7 & 76.7 & 81.4 & 80.9 & 80.8 & 80.5 & 80.1 & 79.6 \\
\hline Gross domestic investment & 30.5 & 30.6 & 24.9 & 23.0 & 21.4 & 21.7 & 21.7 & 21.8 & 22.1 & 22.3 \\
\hline Government & 7.1 & 6.7 & 5.7 & 7.8 & 5.2 & 5.2 & 5.0 & 4.9 & 4.7 & 4.6 \\
\hline Other & 23.4 & 23.9 & 19.2 & 15.2 & 16.2 & 16.5 & 16.7 & 17.0 & 17.4 & 17.7 \\
\hline Gross national savings & 18.9 & 13.0 & 15.3 & 18.0 & 14.4 & 13.4 & 13.9 & 14.2 & 14.7 & 15.1 \\
\hline Government & 3.5 & 0.9 & 0.3 & -0.7 & -1.0 & -0.3 & 0.6 & 1.3 & 1.5 & 1.6 \\
\hline Other & 15.4 & 12.0 & 15.0 & 18.6 & 15.4 & 13.7 & 13.3 & 13.0 & 13.2 & 13.5 \\
\hline Savings-investment balance & -11.6 & -17.6 & -9.6 & -5.0 & -7.0 & -8.3 & -7.8 & -7.6 & -7.4 & -7.2 \\
\hline Government & -3.6 & -5.8 & -5.4 & -8.5 & -6.2 & -5.5 & -4.4 & -3.6 & -3.2 & -3.0 \\
\hline Other & -8.1 & -11.9 & -4.2 & 3.5 & -0.8 & -2.8 & -3.4 & -4.0 & -4.2 & -4.2 \\
\hline \multicolumn{11}{|l|}{ Fiscal operations } \\
\hline Revenue and grants & 32.8 & 32.5 & 29.1 & 25.1 & 23.3 & 23.3 & 23.6 & 23.5 & 23.4 & 23.3 \\
\hline Of which: grants & 3.2 & 2.8 & 4.5 & 1.9 & 1.6 & 1.2 & 1.2 & 1.2 & 1.2 & 1.2 \\
\hline Expenditure and net lending $1 /$ & 36.4 & 38.3 & 34.5 & 33.6 & 29.5 & 28.8 & 28.0 & 27.1 & 26.6 & 26.3 \\
\hline Overall fiscal balance including grants & -3.6 & -5.8 & -5.4 & -8.5 & -6.2 & -5.5 & -4.4 & -3.6 & -3.2 & -3.0 \\
\hline Overall fiscal balance excluding grants & -6.7 & -8.6 & -9.8 & -10.3 & -7.8 & -6.7 & -5.6 & -4.8 & -4.4 & -4.2 \\
\hline Primary fiscal balance excluding grants & -3.7 & -5.6 & -7.5 & -8.1 & -5.5 & -4.3 & -3.2 & -2.6 & -2.1 & -1.7 \\
\hline Government and government-guaranteed net debt & 69.9 & 68.0 & 52.9 & 55.8 & 57.3 & 57.5 & 56.5 & 54.9 & 53.8 & 52.7 \\
\hline Of which: external debt & 49.3 & 43.6 & 22.6 & 21.7 & 19.1 & 16.5 & 14.1 & 12.0 & 10.5 & 9.2 \\
\hline \multicolumn{11}{|l|}{ External sector } \\
\hline Current account balance (including grants), of which: & -11.6 & -17.6 & -9.6 & -5.0 & -7.0 & -8.3 & -7.8 & -7.6 & -7.4 & -7.2 \\
\hline Exports of goods, f.o.b. (\$ billions) & 5.2 & 5.7 & 7.9 & 6.4 & 6.6 & 7.1 & 7.7 & 8.3 & 8.9 & 9.6 \\
\hline Imports of goods, f.o.b. (\$ billions) & 10.3 & 12.2 & 15.1 & 12.5 & 13.5 & 14.3 & 15.2 & 16.4 & 17.5 & 18.7 \\
\hline Oil and oil products ( $\$$ billions) & 2.4 & 2.6 & 3.3 & 2.2 & 2.7 & 2.8 & 3.1 & 3.4 & 3.6 & 3.8 \\
\hline Current account balance (excluding grants) & -17.1 & -19.8 & -15.5 & -8.8 & -9.8 & -9.8 & -9.3 & -9.0 & -8.6 & -8.3 \\
\hline \multirow[t]{2}{*}{ Private capital inflows (net) } & 24.9 & 22.1 & 14.9 & 14.1 & 7.1 & 9.8 & 9.8 & 9.3 & 9.0 & 8.7 \\
\hline & \multicolumn{10}{|c|}{ (Annual percentage changes) } \\
\hline Exports of goods, f.o.b. & 21.0 & 10.1 & 38.6 & -19.8 & 4.2 & 7.5 & 7.3 & 7.8 & 8.0 & 8.2 \\
\hline Imports of goods, f.o.b. & 10.1 & 18.7 & 24.1 & -17.2 & 7.7 & 5.9 & 6.8 & 7.4 & 6.9 & 6.8 \\
\hline \multicolumn{11}{|l|}{ Monetary sector } \\
\hline Broad money & 14.1 & 10.6 & 17.3 & 9.3 & 9.9 & $\ldots$ & $\ldots$ & $\ldots$ & $\ldots$ & $\ldots$ \\
\hline Net foreign assets & 23.4 & 6.2 & -9.7 & 25.1 & -1.7 & $\ldots$ & $\ldots$ & $\ldots$ & $\ldots$ & $\ldots$ \\
\hline Net domestic assets & 5.3 & 15.5 & 44.7 & -0.7 & 19.3 & $\ldots$ & $\ldots$ & $\ldots$ & $\ldots$ & $\ldots$ \\
\hline Credit to private sector & 24.5 & 15.3 & 14.8 & 0.5 & 7.9 & $\ldots$ & $\ldots$ & $\ldots$ & $\ldots$ & $\ldots$ \\
\hline Credit to central government & 8.7 & 22.2 & 60.2 & 18.9 & 24.2 & $\ldots$ & $\cdots$ & $\ldots$ & $\ldots$ & $\ldots$ \\
\hline \multicolumn{11}{|l|}{ Memorandum items: } \\
\hline Gross usable international reserves ( $\$$ millions) & 6,103 & 6,865 & 7,732 & 11,093 & 10,705 & 10,860 & 11,093 & 11,309 & 11,578 & 11,847 \\
\hline In months of prospective imports of GNFS & 5.1 & 4.7 & 6.2 & 8.1 & 7.4 & 7.0 & 6.7 & 6.7 & 6.5 & 6.2 \\
\hline Relative to short-term debt by remaining maturity & 7.3 & 7.9 & 11.6 & 18.4 & 15.7 & 15.1 & 14.3 & 14.8 & 15.6 & 16.0 \\
\hline Budgetary grants ( $\$$ millions) & 470 & 484 & 1,012 & 465 & 423 & 353 & 381 & 423 & 465 & 481 \\
\hline Population (in millions) & 5.60 & 5.72 & 5.85 & 5.99 & 6.13 & 6.27 & 6.41 & 6.56 & 6.71 & 6.86 \\
\hline Nominal per capita GDP $(\$)$ & 2,650 & 2,971 & 3,878 & 4,193 & 4,436 & 4,747 & 5,077 & 5,420 & 5,727 & 6,039 \\
\hline Stock market index (annual percentage change) & -32.6 & 36.3 & -17.0 & -11.5 & $\cdots$ & $\ldots$ & $\ldots$ & $\cdots$ & $\cdots$ & $\cdots$ \\
\hline Real effective exchange rate (end of period, $2000=100$ ) & 94.3 & 90.7 & 101.8 & 97.3 & $\cdots$ & $\cdots$ & $\ldots$ & $\cdots$ & $\cdots$ & $\ldots$ \\
\hline Percent change (+=appreciation; end of period) & -1.2 & -3.8 & 12.2 & -4.4 & $\ldots$ & $\ldots$ & $\ldots$ & $\ldots$ & $\ldots$ & $\ldots$ \\
\hline
\end{tabular}

Sources: Jordanian authorities; and Fund staff estimates and projections.

$1 /$ Includes statistical discrepancy. 
Table 2. Jordan: Summary of Fiscal Operations, 2006-15

\begin{tabular}{|c|c|c|c|c|c|c|c|c|c|c|c|}
\hline & \multirow[b]{2}{*}{2006} & \multirow[b]{2}{*}{2007} & \multirow[b]{2}{*}{2008} & \multicolumn{2}{|c|}{ Prel. Budg.+Suppl. } & \multicolumn{6}{|c|}{ Projections } \\
\hline & & & & 2009 & 2010 & 2010 & 2011 & 2012 & 2013 & 2014 & 2015 \\
\hline & \multicolumn{11}{|c|}{ (In millions of Jordanian dinars) } \\
\hline Total revenue and grants & 3,454 & 3,920 & 4,690 & 4,476 & 4,476 & 4,486 & 4,915 & 5,440 & 5,928 & 6,382 & 6,841 \\
\hline Budgetary revenue & 3,121 & 3,577 & 3,972 & 4,143 & 4,316 & 4,186 & 4,665 & 5,170 & 5,628 & 6,052 & 6,500 \\
\hline Tax revenue & 2,134 & 2,472 & 2,758 & 2,880 & 2,930 & 2,831 & 3,191 & 3,567 & 3,875 & 4,194 & 4,515 \\
\hline Nontax revenue & 987 & 1,105 & 1,214 & 1,263 & 1,386 & 1,354 & 1,474 & 1,603 & 1,753 & 1,859 & 1,984 \\
\hline Grants 1/ & 333 & 343 & 718 & 333 & 160 & 300 & 250 & 270 & 300 & 330 & 340 \\
\hline Total budgetary expenditure & 3,931 & 4,531 & 5,383 & 5,984 & 5,581 & 5,681 & 6,075 & 6,456 & 6,835 & 7,254 & 7,722 \\
\hline Current expenditure, of which: & 3,186 & 3,741 & 4,481 & 4,586 & 4,585 & 4,685 & 4,986 & 5,313 & 5,623 & 5,986 & 6,389 \\
\hline Capital expenditure $2 /$ & 696 & 744 & 875 & 1,328 & 943 & 943 & 1,038 & 1,094 & 1,166 & 1,225 & 1,293 \\
\hline Net lending & 50 & 46 & 26 & 70 & 53 & 53 & 51 & 49 & 47 & 43 & 40 \\
\hline Spending of privatization proceeds & 2 & 22 & 2 & 0 & 0 & 0 & 0 & 0 & 0 & 0 & 0 \\
\hline Statistical discrepancy, net 3/ & -104 & 61 & 171 & 0 & 0 & 0 & 0 & 0 & 0 & 0 & 0 \\
\hline Overall balance, including grants & -375 & -694 & -865 & $-1,508$ & $-1,105$ & $-1,196$ & $-1,161$ & $-1,016$ & -908 & -872 & -882 \\
\hline Foreign financing (net) 4/ & -21 & -115 & $-1,246$ & 113 & $\ldots$ & -183 & -192 & -217 & -208 & -186 & -179 \\
\hline Privatization receipts (net) & 424 & 258 & 229 & 4 & $\ldots$ & 0 & 0 & 0 & 0 & 0 & 0 \\
\hline \multirow[t]{2}{*}{ Domestic financing (net) } & -28 & 551 & 1,882 & 1,391 & $\ldots$ & 1,378 & 1,352 & 1,232 & 1,115 & 1,058 & 1,060 \\
\hline & \multicolumn{11}{|c|}{ (In percent of GDP) } \\
\hline Total revenue and grants & 32.8 & 32.5 & 29.1 & 25.1 & 23.2 & 23.3 & 23.3 & 23.6 & 23.5 & 23.4 & 23.3 \\
\hline Budgetary revenue & 29.7 & 29.7 & 24.7 & 23.3 & 22.4 & 21.7 & 22.1 & 22.4 & 22.3 & 22.2 & 22.1 \\
\hline Tax revenue & 20.3 & 20.5 & 17.1 & 16.2 & 15.2 & 14.7 & 15.1 & 15.5 & 15.4 & 15.4 & 15.4 \\
\hline Nontax revenue & 9.4 & 9.2 & 7.5 & 7.1 & 7.2 & 7.0 & 7.0 & 6.9 & 7.0 & 6.8 & 6.8 \\
\hline Grants 1/ & 3.2 & 2.8 & 4.5 & 1.9 & 0.8 & 1.6 & 1.2 & 1.2 & 1.2 & 1.2 & 1.2 \\
\hline Total budgetary expenditure & 37.4 & 37.6 & 33.4 & 33.6 & 28.9 & 29.5 & 28.8 & 28.0 & 27.1 & 26.6 & 26.3 \\
\hline Current expenditure & 30.3 & 31.0 & 27.8 & 25.7 & 23.8 & 24.3 & 23.6 & 23.0 & 22.3 & 22.0 & 21.7 \\
\hline Capital expenditure 2/ & 6.6 & 6.2 & 5.4 & 7.5 & 4.9 & 4.9 & 4.9 & 4.7 & 4.6 & 4.5 & 4.4 \\
\hline Net lending & 0.5 & 0.4 & 0.2 & 0.4 & 0.3 & 0.3 & 0.2 & 0.2 & 0.2 & 0.2 & 0.1 \\
\hline Spending of privatization proceeds & 0.0 & 0.2 & 0.0 & 0.0 & 0.0 & 0.0 & 0.0 & 0.0 & 0.0 & 0.0 & 0.0 \\
\hline Statistical discrepancy, net 3/ & -1.0 & 0.5 & 1.1 & 0.0 & 0.0 & 0.0 & 0.0 & 0.0 & 0.0 & 0.0 & 0.0 \\
\hline Overall balance including grants & -3.6 & -5.8 & -5.4 & -8.5 & -5.7 & -6.2 & -5.5 & -4.4 & -3.6 & -3.2 & -3.0 \\
\hline Privatization receipts (net) & 4.0 & 2.1 & 1.4 & 0.0 & $\ldots$ & 0.0 & 0.0 & 0.0 & 0.0 & 0.0 & 0.0 \\
\hline Domestic financing (net) & -0.3 & 4.6 & 11.7 & 7.8 & $\ldots$ & 7.1 & 6.4 & 5.3 & 4.4 & 3.9 & 3.6 \\
\hline \multicolumn{12}{|l|}{ Memorandum items: } \\
\hline Overall balance excluding grants & -6.7 & -8.6 & -9.8 & -10.3 & -6.6 & -7.8 & -6.7 & -5.6 & -4.8 & -4.4 & -4.2 \\
\hline Primary balance including grants & -0.5 & -2.7 & -3.0 & -6.3 & -3.3 & -3.9 & -3.1 & -2.0 & -1.4 & -0.9 & -0.6 \\
\hline Primary balance excluding grants & -3.7 & -5.6 & -7.5 & -8.1 & -4.2 & -5.5 & -4.3 & -3.2 & -2.6 & -2.1 & -1.7 \\
\hline Government and guaranteed net debt $5 /$ & 69.9 & 68.0 & 52.9 & 55.8 & $\ldots$ & 57.3 & 57.5 & 56.5 & 54.9 & 53.8 & 52.7 \\
\hline Of which: External & 49.3 & 43.6 & 22.6 & 21.7 & $\ldots$ & 19.1 & 16.5 & 14.1 & 12.0 & 10.5 & 9.2 \\
\hline GDP at market prices (JD millions) 6/ & 10,521 & 12,057 & 16,108 & 17,816 & 19,284 & 19,284 & 21,100 & 23,083 & 25,211 & 27,252 & 29,396 \\
\hline
\end{tabular}

Sources: Jordanian authorities; and Fund staff estimates and projections.

1/ Based on existing commitments, authorities' plans, and staff estimates.

2/ Includes some current expenditure, such as maintenance and wage-related spending

$3 /$ The discrepancy is accounted for in part by the inclusion of non-budgetary accounts in the domestic financing data.

4/ In 2008, foreign financing includes repayment of Paris Club debt, partly financed through domestic financing (drawdown of the privatization account).

5 / Domestic debt is net of government deposits with the banking system.

6/ The 2010 budget ratios to GDP are based on staff's GDP estimates. 
Table 3. Jordan: Summary of Revenues and Expenditures, 2006-15

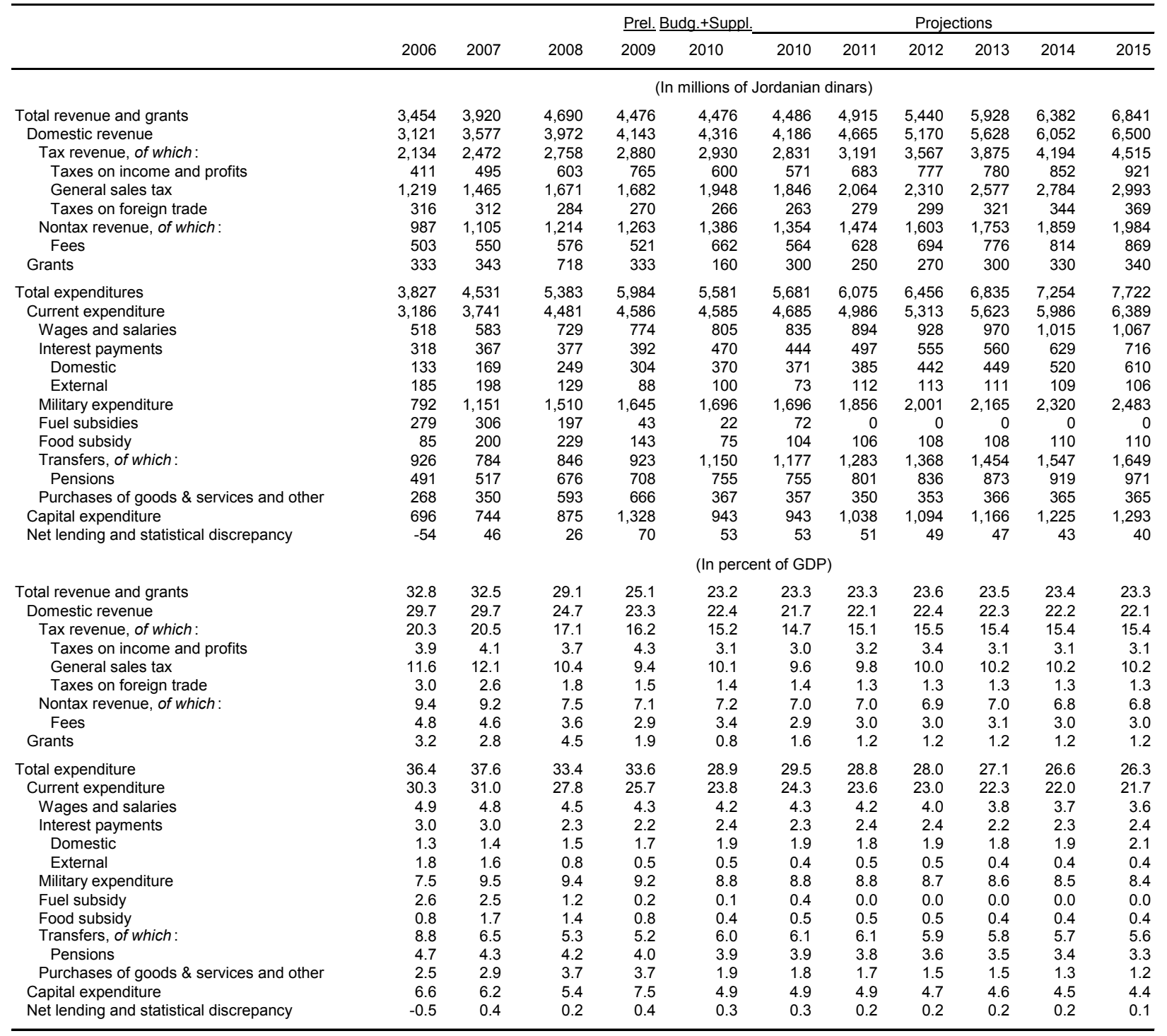

Sources: Jordanian authorities; and Fund staff estimates and projections. 
Table 4. Jordan: Summary Balance of Payments, 2006-15 (In millions of U.S. dollars, unless otherwise noted)

\begin{tabular}{|c|c|c|c|c|c|c|c|c|c|c|}
\hline & \multirow[b]{2}{*}{2006} & \multirow[b]{2}{*}{2007} & \multirow[b]{2}{*}{2008} & \multicolumn{2}{|l|}{ Prel. } & \multicolumn{3}{|c|}{ Proj. } & \multirow[b]{2}{*}{2014} & \multirow[b]{2}{*}{2015} \\
\hline & & & & 2009 & 2010 & 2011 & 2012 & 2013 & & \\
\hline Current account & $-1,726$ & $-2,995$ & $-2,180$ & $-1,254$ & $-1,900$ & $-2,459$ & $-2,550$ & $-2,698$ & $-2,827$ & $-2,964$ \\
\hline Trade balance & $-5,056$ & $-6,451$ & $-7,171$ & $-6,141$ & $-6,832$ & $-7,131$ & $-7,584$ & $-8,113$ & $-8,587$ & $-9,049$ \\
\hline Exports f.o.b. & 5,204 & 5,732 & 7,945 & 6,375 & 6,642 & 7,137 & 7,657 & 8,253 & 8,916 & 9,643 \\
\hline Of which: domestic exports, f.o.b. & 4,132 & 4,490 & 6,250 & 5,040 & 5,440 & 5,815 & 6,216 & 6,698 & 7,236 & 7,829 \\
\hline Imports f.o.b. & 10,260 & 12,183 & 15,116 & 12,515 & 13,474 & 14,268 & 15,241 & 16,367 & 17,504 & 18,692 \\
\hline Of which: food imports, f.o.b. & 1,163 & 1,656 & 2,174 & 1,825 & 1,950 & 2,026 & 2,099 & 2,233 & 2,376 & 2,527 \\
\hline Of which: oil-gas imports, f.o.b. & 2,426 & 2,581 & 3,280 & 2,224 & 2,659 & 2,845 & 3,092 & 3,370 & 3,598 & 3,813 \\
\hline Services (net) & -63 & 31 & 352 & 748 & 866 & 783 & 849 & 948 & 1,057 & 1,176 \\
\hline Of which: travel receipts & 2,060 & 2,311 & 2,946 & 2,915 & 3,294 & 3,426 & 3,666 & 3,922 & 4,197 & 4,491 \\
\hline Income (net) & 453 & 647 & 696 & 611 & 544 & 592 & 771 & 981 & 1,069 & 1,166 \\
\hline Of which: investment income (net) & 84 & 206 & 169 & 132 & 17 & 13 & 134 & 279 & 298 & 317 \\
\hline Current transfers (net) & 2,940 & 2,779 & 3,943 & 3,528 & 3,523 & 3,297 & 3,414 & 3,486 & 3,634 & 3,743 \\
\hline Public (net) & 810 & 374 & 1,341 & 966 & 752 & 449 & 491 & 490 & 491 & 494 \\
\hline Private (net) & 2,130 & 2,405 & 2,602 & 2,562 & 2,771 & 2,848 & 2,923 & 2,996 & 3,143 & 3,248 \\
\hline Of which: remittances (net) & 2,160 & 2,571 & 2,746 & 2,679 & 2,897 & 2,977 & 3,056 & 3,135 & 3,289 & 3,401 \\
\hline Capital account & 3,440 & 3,416 & 1,100 & 3,769 & 1,754 & 2,689 & 2,923 & 3,047 & 3,190 & 3,312 \\
\hline Public sector (net) & -257 & -348 & $-2,279$ & 220 & -189 & -227 & -271 & -264 & -283 & -297 \\
\hline Disbursements & 270 & 185 & 221 & 590 & 251 & 251 & 251 & 251 & 251 & 252 \\
\hline Amortization & 526 & 533 & 2,500 & 369 & 440 & 478 & 521 & 515 & 533 & 548 \\
\hline Of which: Paris Club debt buyback & $\ldots$ & $\ldots$ & 2,103 & $\ldots$ & $\ldots$ & $\ldots$ & $\cdots$ & $\cdots$ & .. & \\
\hline Private sector (net) & 3,696 & 3,764 & 3,380 & 3,549 & 1,943 & 2,916 & 3,193 & 3,311 & 3,473 & 3,609 \\
\hline Direct foreign investment & 3,357 & 1,902 & 2,816 & 2,351 & 2,445 & 2,689 & 2,824 & 3,021 & 3,233 & 3,427 \\
\hline Portfolio flows & 37 & 840 & 574 & -630 & 20 & 80 & 96 & 110 & 132 & 159 \\
\hline Other capital plus E\&Os & 302 & 1,022 & -10 & 1,829 & -522 & 147 & 274 & 179 & 108 & 23 \\
\hline Other capital flows & 35 & 1,769 & -160 & 992 & $\ldots$ & $\ldots$ & $\ldots$ & $\ldots$ & $\ldots$ & $\ldots$ \\
\hline Errors and omissions & 267 & -747 & 150 & 837 & $\ldots$ & $\ldots$ & $\ldots$ & $\ldots$ & $\ldots$ & $\ldots$ \\
\hline Overall balance & 1,713 & 422 & $-1,079$ & 2,515 & -146 & 230 & 372 & 348 & 363 & 348 \\
\hline Financing & $-1,713$ & -422 & 1,079 & $-2,515$ & 146 & -230 & -372 & -348 & -363 & -348 \\
\hline Increase in NFA (-) $1 /$ & $-1,897$ & -571 & 1,139 & $-2,499$ & 216 & -176 & -305 & -290 & -340 & -340 \\
\hline Central bank & $-1,294$ & -893 & -740 & $-3,653$ & 402 & -156 & -232 & -216 & -269 & -269 \\
\hline Commercial banks & -603 & 322 & 1,878 & 1,154 & -186 & -21 & -73 & -74 & -71 & -71 \\
\hline IMF, net (expectations basis) & -88 & -76 & -59 & -16 & -2 & 0 & 0 & 0 & 0 & 0 \\
\hline Purchases & 0 & 0 & 0 & 0 & 0 & 0 & 0 & 0 & 0 & 0 \\
\hline Repur & 88 & 76 & 59 & 16 & 2 & 0 & 0 & 0 & 0 & 0 \\
\hline Relief fro & 63 & 40 & 0 & 0 & 0 & 0 & 0 & 0 & 0 & 0 \\
\hline Debt rescheduling/exceptional financing & 209 & 185 & 0 & 0 & 0 & 0 & 0 & 0 & 0 & 0 \\
\hline Financing gap & 0 & 0 & 0 & 0 & 0 & 0 & 0 & 0 & 0 & 0 \\
\hline \multicolumn{11}{|l|}{ Memorandum items: } \\
\hline Gross usable internationa & 6,103 & 6,865 & 7,732 & 11,093 & 10,705 & 10,860 & 11,093 & 11,309 & 11,578 & 11,847 \\
\hline In month & 5.1 & 4.7 & 6.2 & 8.1 & 7.4 & 7.0 & 6.7 & 6.6 & 6.3 & 6.1 \\
\hline Merchandis & 21.0 & 10.1 & 38.6 & -19.8 & 4.2 & 7.5 & 7.3 & 7.8 & 8.0 & 8.2 \\
\hline Of which: domestic exports & 13.9 & 8.7 & 39.2 & -19.4 & 7.9 & 6.9 & 6.9 & 7.7 & 8.0 & 8.2 \\
\hline ing exports & 16.4 & 4.6 & 19.0 & -11.0 & 8.2 & 7.0 & 7.0 & 7.0 & 7.0 & 7.0 \\
\hline Export of GNFS growth, percent & 22.2 & 14.4 & 33.9 & -12.0 & 6.5 & 6.2 & 7.3 & 7.5 & 7.6 & 7.7 \\
\hline Import growth, percent & 10.1 & 18.7 & 24.1 & -17.2 & 7.7 & 5.9 & 6.8 & 7.4 & 6.9 & 6.8 \\
\hline Of which: excl.oil/food & 8.3 & 19.1 & 21.6 & -12.3 & 4.6 & 6.0 & 6.9 & 7.1 & 7.1 & 7.1 \\
\hline Import of GNFS growth, percent & 11.6 & 18.7 & 22.6 & -15.2 & 7.9 & 6.3 & 6.9 & 7.1 & 6.8 & 6.6 \\
\hline Import oil price (\$ per barrel) & 62.3 & 71.3 & 92.0 & 61.5 & 77.1 & 80.0 & 82.8 & 84.0 & 85.0 & 85.0 \\
\hline Current account (in percent of GDP) & -11.6 & -17.6 & -9.6 & -5.0 & -7.0 & -8.3 & -7.8 & -7.6 & -7.4 & -7.2 \\
\hline Current account, excl. grants (percent of GDP) & -17.1 & -19.8 & -15.5 & -8.8 & -9.8 & -9.8 & -9.3 & -9.0 & -8.6 & -8.3 \\
\hline Private capita & 24.9 & 22.1 & 14.9 & 14.1 & 7.1 & 9.8 & 9.8 & 9.3 & 9.0 & 8.7 \\
\hline External government debt (percent of GDP) & 49.3 & 43.6 & 22.6 & 21.7 & 19.1 & 16.5 & 14.1 & 12.0 & 10.5 & 9.2 \\
\hline GDP (\$ millions) & 14,839 & 17,005 & 22,706 & 25,113 & 27,175 & 29,752 & 32,547 & 35,547 & 38,425 & 41,448 \\
\hline
\end{tabular}

Sources: Jordanian authorities; and Fund staft estimates and projections.

1/ The change in Fund credit outstanding is deducted from the change in NFA from monetary survey.

2/ The difference between the face value of debt reduction and the cost of debt operations.

$3 /$ In months of prospective import of goods and nonfactor services (GNFS) of the following year, excluding imports for re-export purposes. 
Table 5. Jordan: Summary Monetary Survey, 2005-10

\begin{tabular}{|c|c|c|c|c|c|c|}
\hline & 2005 & 2006 & 2007 & 2008 & 2009 & $\frac{\text { Proj }}{2010}$ \\
\hline & \multicolumn{6}{|c|}{ (Stocks in millions of Jordanian dinars) } \\
\hline Net foreign assets & 6,002 & 7,410 & 7,868 & 7,103 & 8,889 & 8,737 \\
\hline Net domestic assets & 6,362 & 6,700 & 7,738 & 11,201 & 11,125 & 13,266 \\
\hline Net claims on central government $1 /$ & 1,800 & 1,459 & 2,091 & 4,095 & 4,585 & 5,963 \\
\hline Of which: budgetary central government $2 /$ & 1,908 & 1,825 & 2,212 & 4,181 & 4,775 & 6,153 \\
\hline Claims on nonfinancial public enterprises & 528 & 521 & 624 & 603 & 411 & 444 \\
\hline Claims on financial institutions & 153 & 214 & 277 & 335 & 238 & 238 \\
\hline Claims on the private sector & 7,669 & 9,546 & 11,003 & 12,636 & 12,693 & 13,701 \\
\hline Other items (net) & $-3,787$ & $-5,041$ & $-6,259$ & $-6,517$ & $-6,874$ & $-7,080$ \\
\hline Broad money & 12,364 & 14,110 & 15,607 & 18,304 & 20,013 & 22,003 \\
\hline Currency in circulation & 1,657 & 2,027 & 2,172 & 2,665 & 2,680 & 3,122 \\
\hline Jordanian dinar deposits & 7,795 & 8,760 & 9,809 & 12,314 & 14,445 & 15,706 \\
\hline \multirow[t]{2}{*}{ Foreign currency deposits } & 2,912 & 3,322 & 3,625 & 3,325 & 2,889 & 3,176 \\
\hline & \multicolumn{6}{|c|}{ (Cumulative flows in millions of Jordanian dinars) } \\
\hline Net foreign assets & 191 & 1,407 & 459 & -766 & 1,786 & -152 \\
\hline Net domestic assets & 1,602 & 338 & 1,038 & 3,463 & -77 & 2,142 \\
\hline Net claims on central government $1 /$ & 401 & -340 & 632 & 2,004 & 490 & 1,378 \\
\hline Of which: budgetary central government 2/ & 318 & -83 & 387 & 1,969 & 594 & 1,378 \\
\hline Claims on nonfinancial public enterprises & 56 & -8 & 103 & -21 & -192 & 34 \\
\hline Claims on financial institutions & 58 & 62 & 63 & 58 & -97 & 0 \\
\hline Claims on the private sector & 1,784 & 1,878 & 1,457 & 1,633 & 58 & 1,007 \\
\hline Other items (net) & -686 & $-1,253$ & $-1,218$ & -258 & -357 & -206 \\
\hline Broad money & 1,793 & 1,746 & 1,497 & 2,697 & 1,709 & 1,990 \\
\hline Currency in circulation & 243 & 370 & 145 & 492 & 15 & 442 \\
\hline Jordanian dinar deposits & 1,340 & 965 & 1,049 & 2,505 & 2,130 & 1,261 \\
\hline \multirow[t]{2}{*}{ Foreign currency deposits } & 210 & 411 & 303 & -300 & -436 & 286 \\
\hline & \multicolumn{6}{|c|}{ (Cumulative flows in percent of beginning-of-period broad money) } \\
\hline Net foreign assets & 1.8 & 11.4 & 3.3 & -4.9 & 9.8 & -0.8 \\
\hline Net domestic assets & 15.2 & 2.7 & 7.4 & 22.2 & -0.4 & 10.7 \\
\hline Net claims on general government $1 /$ & 3.8 & -2.8 & 4.5 & 12.8 & 2.7 & 6.9 \\
\hline Of which: budgetary central government $2 /$ & 3.0 & -0.7 & 2.7 & 12.6 & 3.2 & 6.9 \\
\hline Claims on nonfinancial public enterprises & 0.5 & -0.1 & 0.7 & -0.1 & -1.1 & 0.2 \\
\hline Claims on financial institutions & 0.5 & 0.5 & 0.4 & 0.4 & -0.5 & 0.0 \\
\hline Claims on the private sector & 16.9 & 15.2 & 10.3 & 10.5 & 0.3 & 5.0 \\
\hline Other items (net) & -6.5 & -10.1 & -8.6 & -1.7 & -1.9 & -1.0 \\
\hline Broad money & 17.0 & 14.1 & 10.6 & 17.3 & 9.3 & 9.9 \\
\hline Currency in circulation & 2.3 & 3.0 & 1.0 & 3.2 & 0.1 & 2.2 \\
\hline Jordanian dinar deposits & 12.7 & 7.8 & 7.4 & 16.0 & 11.6 & 6.3 \\
\hline Foreign currency deposits & 2.0 & 3.3 & 2.1 & -1.9 & -2.4 & 1.4 \\
\hline \multicolumn{7}{|l|}{ Memorandum items: } \\
\hline Annual broad money growth (percent) & 17.0 & 14.1 & 10.6 & 17.3 & 9.3 & 9.9 \\
\hline Annual JD broad money growth (percent) & 20.1 & 14.1 & 11.1 & 25.0 & 14.3 & 9.9 \\
\hline Annual private sector credit growth (percent) & 30.3 & 24.5 & 15.3 & 14.8 & 0.5 & 7.9 \\
\hline
\end{tabular}

Sources: Jordanian authorities; and Fund staff estimates and projections.

1 / Includes central budgetary government and own-budget agencies, but excludes SSC.

2/ Excludes UN compensation funds and Brady bonds held by Jordanian banks. 
Table 6. Jordan: Summary Accounts of the Central Bank of Jordan, 2005-10

\begin{tabular}{|c|c|c|c|c|c|c|}
\hline & 2005 & 2006 & 2007 & 2008 & 2009 & $\frac{\text { Proj. }}{2010}$ \\
\hline & \multicolumn{6}{|c|}{ (Stocks in millions of Jordanian dinars) } \\
\hline Net foreign assets & 4,004 & 4,984 & 5,671 & 6,238 & 8,842 & 8,558 \\
\hline Of which: SDRs & 1 & 1 & 2 & 3 & 164 & 164 \\
\hline Net domestic assets & $-1,183$ & $-1,598$ & $-2,018$ & $-1,725$ & $-4,178$ & $-3,430$ \\
\hline Net claims on central government $1 /$ & 914 & 152 & 173 & 980 & 671 & 671 \\
\hline Net claims on NFPEs and the SSC & -24 & -19 & -61 & -212 & -69 & -69 \\
\hline Net claims on financial institutions & 75 & 94 & 99 & 86 & 60 & 60 \\
\hline Net claims on private sector & 18 & 18 & 18 & 19 & 19 & 19 \\
\hline Net claims on commercial banks & 151 & 425 & 211 & -672 & $-3,644$ & $-2,945$ \\
\hline CDs & $-2,280$ & $-2,153$ & $-1,977$ & $-1,166$ & -150 & -250 \\
\hline Other items, net (asset: +) & -39 & -115 & -482 & -759 & $-1,066$ & -916 \\
\hline Jordanian dinar reserve money & 2,821 & 3,386 & 3,653 & 4,513 & 4,664 & 5,128 \\
\hline Currency & 1,783 & 2,201 & 2,350 & 2,872 & 2,886 & 3,429 \\
\hline Commercial bank reserves & 1,038 & 1,185 & 1,302 & 1,641 & 1,778 & 1,699 \\
\hline \multirow[t]{2}{*}{ Of which: required reserves } & 566 & 715 & 834 & 1,297 & 1,082 & 1,317 \\
\hline & \multicolumn{6}{|c|}{ (Cumulative flows in millions of Jordanian dinars from beginning of period) } \\
\hline Net foreign assets & 37 & 980 & 687 & 567 & 2,605 & -284 \\
\hline Of which: SDRs & -1 & 1 & 1 & 1 & 162 & 0 \\
\hline Net domestic assets & 421 & -415 & -420 & 294 & $-2,454$ & 748 \\
\hline Net claims on central government $1 /$ & 261 & -762 & 21 & 806 & -309 & 0 \\
\hline Net claims on NFPEs and the SSC & 63 & 4 & -42 & -151 & 143 & 0 \\
\hline Net claims on financial institutions & 50 & 18 & 5 & -13 & -26 & 0 \\
\hline Net claims on private sector & 0 & -1 & 0 & 1 & 0 & 0 \\
\hline Net claims on commercial banks & -161 & 274 & -214 & -883 & $-2,972$ & 699 \\
\hline CDs & 255 & 127 & 176 & 811 & 1,016 & -100 \\
\hline Other items, net (asset: +) & -47 & -76 & -367 & -277 & -306 & 149 \\
\hline Jordanian dinar reserve money & 458 & 565 & 267 & 860 & 151 & 464 \\
\hline Currency & 276 & 418 & 149 & 521 & 15 & 542 \\
\hline \multirow[t]{2}{*}{ Commercial banks' reserves } & 183 & 147 & 118 & 339 & 136 & -78 \\
\hline & \multicolumn{6}{|c|}{ (Cumulative flows in percent of beginning-of-period reserve money) } \\
\hline Net foreign assets & 1.6 & 34.7 & 20.3 & 15.5 & 57.7 & -6.1 \\
\hline Net domestic assets & 17.8 & -14.7 & -12.4 & 8.0 & -54.4 & 16.0 \\
\hline Net claims on central government $1 /$ & 11.1 & -27.0 & 0.6 & 22.1 & -6.8 & 0.0 \\
\hline Net claims on NFPEs and the SSC & 2.7 & 0.2 & -1.2 & -4.1 & 3.2 & 0.0 \\
\hline Net claims on financial institutions & 2.1 & 0.7 & 0.2 & -0.4 & -0.6 & 0.0 \\
\hline Net claims on private sector & 0.0 & 0.0 & 0.0 & 0.0 & 0.0 & 0.0 \\
\hline Net claims on commercial banks & -6.8 & 9.7 & -6.3 & -24.2 & -65.9 & 15.0 \\
\hline CDs & 10.8 & 4.5 & 5.2 & 22.2 & 22.5 & -2.1 \\
\hline Other items, net (asset: +) & -2.0 & -2.7 & -10.8 & -7.6 & -6.8 & 3.2 \\
\hline Jordanian dinar reserve money & 19.4 & 20.0 & 7.9 & 23.6 & 3.3 & 9.9 \\
\hline Currency & 11.7 & 14.8 & 4.4 & 14.3 & 0.3 & 11.6 \\
\hline Commercial bank reserves & 7.7 & 5.2 & 3.5 & 9.3 & 3.0 & -1.7 \\
\hline \multicolumn{7}{|l|}{ Memorandum items: } \\
\hline Gross usable international reserves (\$ millions) & 4,745 & 6,103 & 6,865 & 7,732 & 11,093 & 10,705 \\
\hline As a ratio to JD broad money (in percent) & 35.6 & 40.1 & 40.6 & 36.6 & 45.9 & 40.3 \\
\hline As a ratio of JD reserve money (in percent) & 119.3 & 127.8 & 133.3 & 121.5 & 168.6 & 148.0 \\
\hline Net international reserves (JD millions) & 3,222 & 4,270 & 4,904 & 5,469 & 8,074 & 7,791 \\
\hline Money multiplier (for JD liquidity) & 3.4 & 3.2 & 3.3 & 3.3 & 3.7 & 3.7 \\
\hline
\end{tabular}

Sources: Jordanian authorities; and Fund staff estimates and projections.

1/ Excludes UN compensation funds and Brady bonds held by Jordanian banks. 
Table 7. Jordan: Indicators of Financial Vulnerability, 2003-09 (End-of-period, unless otherwise noted)

\begin{tabular}{|c|c|c|c|c|c|c|c|}
\hline & 2003 & 2004 & 2005 & 2006 & 2007 & 2008 & 2009 \\
\hline Monetary and financial indicators & \multicolumn{7}{|c|}{ (In percent of GDP, unless otherwise indicated) } \\
\hline Gross domestic currency public debt (including own-budget agencies) & 25.1 & 25.7 & 27.6 & 28.2 & 30.7 & 35.8 & 40.0 \\
\hline Central government net domestic financing & 4.3 & 2.6 & 5.6 & -0.3 & 4.6 & 11.7 & 7.7 \\
\hline Broad money (annual growth, in percent) & 12.4 & 11.7 & 17.0 & 14.1 & 10.6 & 17.3 & 9.3 \\
\hline Broad domestic currency liquidity (M2) (annual growth, in percent) & 11.9 & 8.6 & 20.1 & 14.1 & 11.1 & 25.0 & 14.3 \\
\hline Private sector credit (annual growth, in percent) & 3.5 & 17.3 & 30.3 & 24.5 & 15.3 & 14.8 & 0.5 \\
\hline \multicolumn{8}{|l|}{ Banking sector indicators } \\
\hline Nonperforming loans (excluding interest in suspense, as percent of loans) & 15.5 & 10.3 & 6.6 & 4.3 & 4.1 & 4.2 & 6.7 \\
\hline Nonperforming loans (as percent of capital and reserves) & 73.2 & 46.2 & 28.3 & 15.9 & 15.9 & 17.5 & 18.1 \\
\hline Provisions against nonperforming loans (excl. interest in suspense, in percent) & 51.9 & 63.8 & 78.4 & 79.6 & 67.8 & 63.4 & 51.9 \\
\hline Risk-weighted capital adequacy ratio (in percent) & 15.9 & 17.8 & 17.6 & 21.4 & 20.8 & 18.4 & 19.6 \\
\hline Leverage (equity to assets ratio, in percent) & 7.5 & 8.9 & 10.5 & 13.2 & 13.3 & 12.9 & 13.0 \\
\hline Construction loans in total private credit to residents (in percent) & 17.2 & 17.4 & 16.4 & 17.4 & 18.7 & 19.3 & 21.4 \\
\hline \multirow[t]{2}{*}{ Credit to private sector (in percent of GDP) } & 61.5 & 72.7 & 85.6 & 90.7 & 91.3 & 78.4 & 71.2 \\
\hline & \multicolumn{7}{|c|}{ (In millions of US\$, unless otherwise indicated) } \\
\hline \multicolumn{8}{|l|}{ Foreign currency and external debt indicators } \\
\hline Gross external public debt & 7,599 & 7,541 & 7,132 & 7,315 & 7,409 & 5,136 & 5,464 \\
\hline In percent of GDP & 74.5 & 66.1 & 56.5 & 49.3 & 43.6 & 22.6 & 21.7 \\
\hline Short-term external debt & 860 & 959 & 819 & 835 & 867 & 669 & 602 \\
\hline Total foreign liabilities of central bank & 595 & 494 & 393 & 412 & 343 & 439 & 440 \\
\hline Total foreign liabilities of commercial banks & 4,379 & 4,892 & 5,234 & 5,946 & 6,760 & 6,740 & 6,970 \\
\hline Commercial banks' net foreign asset position & 1,801 & 2,163 & 2,329 & 2,803 & 2,431 & 2,635 & 2,543 \\
\hline \multicolumn{8}{|l|}{ Official reserves indicators } \\
\hline Gross usable reserves $1 /$ & 4,740 & 4,826 & 4,745 & 6,103 & 6,865 & 7,732 & 11,093 \\
\hline In percent of M2 & 35.5 & 32.4 & 27.2 & 30.7 & 31.2 & 34.7 & 49.3 \\
\hline Net international reserves $1 /$ & 4,343 & 4,442 & 4,544 & 6,023 & 6,917 & 6,898 & 6,960 \\
\hline In percent of M2 & 32.5 & 29.8 & 26.1 & 30.3 & 31.4 & 31.0 & 30.9 \\
\hline In percent of short-term external debt & 505 & 463 & 555 & 721 & 798 & 1,031 & 1,155 \\
\hline \multicolumn{8}{|l|}{ External current account indicators (annual flows) } \\
\hline Merchandise exports, f.o.b. & 3,082 & 3,883 & 4,302 & 5,204 & 5,732 & 7,945 & 6,375 \\
\hline Annual changes in percent & 11.2 & 26.0 & 10.8 & 21.0 & 10.1 & 38.6 & -19.8 \\
\hline Merchandise imports, f.o.b. & 5,078 & 7,261 & 9,318 & 10,260 & 12,183 & 15,116 & 12,515 \\
\hline Annual changes in percent & 12.8 & 43.0 & 28.3 & 10.1 & 18.7 & 24.1 & -17.2 \\
\hline Current account balance including grants & 1,172 & 8 & $-2,271$ & $-1,726$ & $-2,995$ & $-2,180$ & $-1,254$ \\
\hline In percent of GDP & 11.5 & 0.1 & -18.0 & -11.6 & -17.6 & -9.6 & -5.0 \\
\hline
\end{tabular}

Sources: Jordanian authorities; and Fund staff estimates.

$1 /$ Excluding foreign currency deposits held by commercial banks with the central bank. 


\title{
Appendix 1. Credit Slowdown: Supply or Demand Driven? ${ }^{1}$
}

\begin{abstract}
The purpose of this Appendix is to analyze the slowdown in credit activity in Jordan following the global financial crisis, which has corresponded with a widening gap between Central Bank of Jordan (CBJ) and U.S. Federal Reserve policy rates, an increase in the real lending rate, and mounting excess reserves of banks. The importance of the credit slowdown for Jordanian economic development cannot be underestimated, given the country's Jordan: Credit to the Private Sector and Interest Rates
\end{abstract} historically large financial deepening indicators (e.g., the share of banking sector credit in GDP is around 80 percent).

\section{Understanding whether sluggish credit activity is related to constrained supply or weak demand for credit is important from a policy perspective. If the reduction of credit flows is mainly a response to tightened credit standards by banks, then targeted monetary easing coupled with}

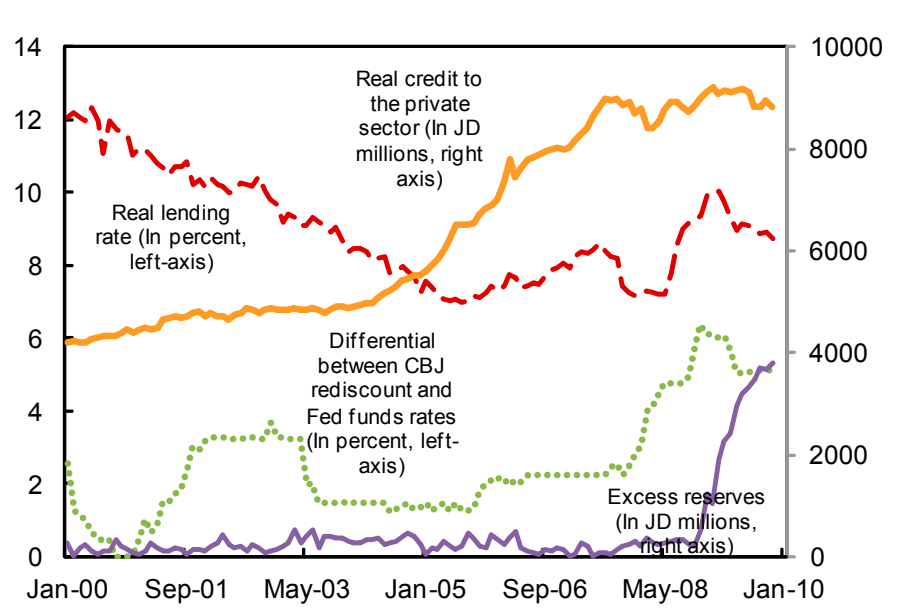
regulatory measures aimed at relaxing prudential norms may be needed to remove the obstacles for credit growth. ${ }^{2}$ Alternatively, if the reduction in credit flows is mostly driven by the decline in credit demand amid slower business activity, then economic policies aimed at expanding aggregate demand might be more effective in stimulating credit growth.

To disentangle the relative role of credit and demand factors, we apply the methodology of Laffont and Garcia (1977). ${ }^{3}$ According to this framework, at a given point in time the credit market can exhibit temporary disequilibrium (excess supply or excess demand) owing to imperfect flexibility in the interest rate. Hence, the observed decline in real credit can be either due to falling supply of credit, or falling demand for credit, or both. The identification problem is solved by using exclusion restrictions on the supply and demand functions (e.g., banks' lending capacity affects the supply of credit, but not demand for credit). Maddala and Nelson (1974) discuss the appropriate maximum likelihood method for this class of disequilibrium models, which has been used for empirical analysis of credit markets in different countries.

\footnotetext{
${ }^{1}$ Prepared by Tigran Poghosyan (MCD).

${ }^{2}$ Among others, this view has been advocated by those favoring countercyclical regulation of banks, according to which capital requirements imposed on banks should be relaxed in times of economic slowdown and strengthened in times of economic boom.

${ }^{3}$ See Laffont, J-J., and Garcia, R. (1977), "Disequilibrium Econometrics for Business Loans," Econometrica, Vol. 45(5): pp. 1187-1204. This approach was applied for analyzing credit slowdown in Finland (Pazarbasioglu, C., 1997, "A Credit Crunch? Finland in the Aftermath of the Banking Crisis," IMF Staff Papers, Vol. 44(3): pp. 315-27), East Asia (Ghosh, A., and Ghosh, S., 1999, "East Asia in the Aftermath: Was There a Crunch?," IMF Working Paper 99/38), and Latin America (Barajas, A., and Steiner, R., 2002, "Credit Stagnation in Latin America," IMF Working Paper 02/53), among others.
} 


\section{We use the following variables as determinants of credit supply:}

- $\quad$ Return on credit (i). This variable, approximated by the real lending rate (nominal loan rate minus smoothed inflation ${ }^{4}$ ), indicates the rate of return raised by banks from credit provision (positive coefficient expected).

- $\quad$ Differential between CBJ re-discount rate and the U.S. Federal Reserve's (Fed) funds rate (im). Given the peg of the Jordanian dinar against the U.S. dollar, monetary policy in Jordan is closely linked to monetary policy in the U.S. Hence, the interest differential between policy rates in Jordan and the U.S. indicates the relative stance of monetary policies in these two countries (negative coefficient expected).

- $\quad$ Future economic prospects $\left(I P^{e}\right)$. Banks are expected to expand credit supply when expecting brighter economic prospects for the economy. We proxy economic prospects by the smoothed industrial production index taken with a lag (positive coefficient expected).

- $\quad$ Lending capacity (LC). Given expected returns on lending, banks should take into account the amount of available resources in deciding the amount of their credit portfolio. We proxy the real lending capacity of banks by the difference between total deposits and required reserves in the CBJ overnight facility deflated by the CPI (positive coefficient expected).

- Economic uncertainty (UNC). We proxy economic uncertainty by using a rolling standard deviation of the log difference between the monthly Amman Stock Exchange index and its smoothed value taken with a lag (negative coefficient expected).

\section{Credit demand is modeled as a function of the following variables:}

- $\quad$ Cost of credit (i'). The demand for bank credit is expected to depend negatively on its cost as proxied by the real lending rate (negative coefficient expected).

- $\quad$ Future economic prospects $\left(I P^{e}\right)$. Developments in the macroeconomic and business environment influence the decision of firms to expand or contract their business, which is crucial for credit applications (positive coefficient expected).

- $\quad$ Lagged growth of real Amman Stock Exchange index (ASE). The impact of stock market activity on demand for bank credit is a priori unclear. On the one hand, expansion in stock market activity may increase demand for credit due to improved economic prospects. On the other hand, a rising value of stocks might improve the ability of businesses to acquire external funding from the financial market and reduce their demand for bank credit (the sign of the coefficient is uncertain).

- Iraq war effect ( $T$ and $T s q)$. The demand equation also features a linear trend and its square, beginning in 2004 (in logs). These variables enter to capture the impact of the inflow of Iraqi refugees on credit demand in Jordan, as evidenced by a rapid acceleration of observed credit volumes since the beginning of the war. The inclusion of the quadratic term ensures that the marginal effect of the trend is diminishing over time, as refugees are expected to return to Iraq after stabilization of its economic situation, or to move to other countries outside the region.

\footnotetext{
${ }^{4}$ Inflation is smoothed using MA $(4,1,4)$ representation using the following formula: $1 / 9^{*}\left(x_{t-4}+x_{t-3}+x_{t-2}+x_{t-1}+x_{t}+x_{t+1}+x_{t+2}+x_{t+3}+x_{t+4}\right)$, where $x_{t}$ is monthly CPI inflation. This approach was applied also for smoothing the growth of the industrial production and stock market indices.
} 
Table 1 displays estimation results of the disequilibrium model of credit for Jordan, using data for the period December 1998 to January 2010. Most of the coefficients are significant and all have expected signs. Standard deviation errors in both supply and demand equations are significantly different from zero, providing support for the chosen model specification.

Table 1. Maximum Likelihood Estimation of the Disequilibrium Model

\begin{tabular}{lrrr}
\hline Credit supply & & Credit demand & $-0.02^{* * *}$ \\
\hline Real lending rate & $0.04^{* *}$ & Real lending rate & {$[-7.19]$} \\
& {$[3.01]$} & & $0.51^{* * *}$ \\
Differential between CBJ & $-0.03^{*}$ & Industrial production index & {$[8.97]$} \\
rediscount and Fed fund rates & {$[-2.17]$} & (lagged) & $-0.01^{* * *}$ \\
Industrial production index & $2.94^{* * *}$ & Lagged real ASE index growth & {$[-3.53]$} \\
(lagged) & {$[7.69]$} & (smoothed) & $-0.09^{* * *}$ \\
Standard deviation of ASE index & -0.02 & Time trend (logs) & {$[-9.98]$} \\
growth (lagged) & {$[-1.37]$} & & $0.05^{* * *}$ \\
Lending capacity & $0.47^{*}$ & Time trend^2 (logs) & {$[20.10]$} \\
& {$[2.19]$} & & $6.42^{* * *}$ \\
Constant & $-9.15^{* * *}$ & Constant & {$[23.15]$} \\
\hline Number of obs. & {$[-7.32]$} & & $0.04^{* * *}$ \\
Log-likelihood & 134 & St. Dev. of supply equation error & {$[6.39]$} \\
Akaike information criteria & 306 & & $0.02^{* * *}$ \\
Bayes-Schwartz information criteria & -584 & St. Dev. of demand equation error & {$[12.86]$} \\
\hline
\end{tabular}

Notes: Dependent variable is real credit to the private sector (in logs).

Estimations are performed using the the $\mathrm{BHHH}$ iterative procedure. $t$-statistics are reported in brackets.

${ }^{*},{ }^{* *}$, and ${ }^{* * *}$ denote significance at 10, 5, and 1 percent levels, respectively.

The estimations suggest that both supply and demand for credit in the Jordanian banking system are positively affected by expected economic prospects. Similarly, the real lending rate has a positive impact on credit supply, while its impact on credit demand is negative. In addition to the lending rate, the supply of credit is also affected by the differential between the CBJ rediscount and the U.S. Federal Reserve's (Fed) funds rate, which proxies the tightness of CBJ monetary policy relative to the Fed's monetary policy. Hence, a higher CBJ policy rate increases bank returns on excess reserves, further discouraging lending to the real sector.

In addition to the price effects, we single out two possible motives governing the supply of bank credit: availability of lendable resources (ability to lend) and risk aversion (willingness to lend in uncertain times). The coefficient of lending capacity is strongly significant and positive, suggesting that higher lending capacity expands banks' potential to lend. Similarly, economic uncertainty has a negative impact on banks' willingness to lend. The magnitude of the latter coefficient is small (and statistically insignificant) relative to the former (0.47), suggesting that while banks slightly reduce credit supply in times of financial market volatility, the main factor driving credit supply is the availability of funds.

Finally, we find negative association between stock market activity and demand for credit. This implies that sluggish stock market developments put additional pressure on the ability of firms to acquire external funding, generating additional demand for bank credit. Credit demand has also been affected by the war in Iraq, as shown by the significant coefficients of trend variables. 
The figures below display estimates of demand for and supply of credit obtained from the disequilibrium model, and their deviations from observed volumes of lending. The plotted credit supply and demand series suggest that the recent slowdown in credit flows is mainly driven by sluggish credit supply, affected by the widening differential between the $\mathrm{CBJ}$ rediscount and Fed funds rates. The demand for credit has also been affected in the wake of the global financial crisis. Credit demand flattened in 2008 amid the slowdown in Jordanian economic activity, but has rebounded since the beginning of 2009 as declining stock prices have dried up alternative sources of external funding for businesses.

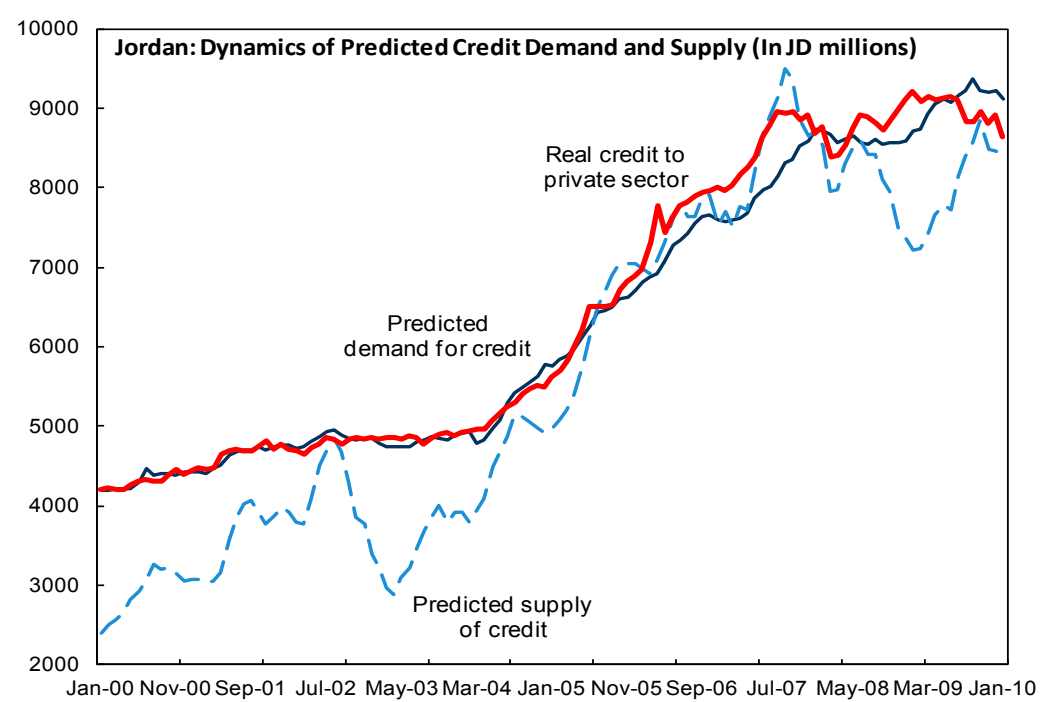

Starting in mid-2009, the ability of banks to potentially expand the supply of credit has risen due to a combination of the following factors: (i) reduction of the CBJ policy rate and its differential with the Fed funds rate; (ii) elimination of the issuance of CBJ CDs and consequent accumulation of excess reserves by commercial banks; and (iii) the potential increase in deposit inflows (including unrecorded financial flows from abroad). Nevertheless, the predicted supply of credit by the end of the sample (January 2010) is still about 7 percent lower than predicted demand, suggesting that credit supply still has a large potential for further expansion.

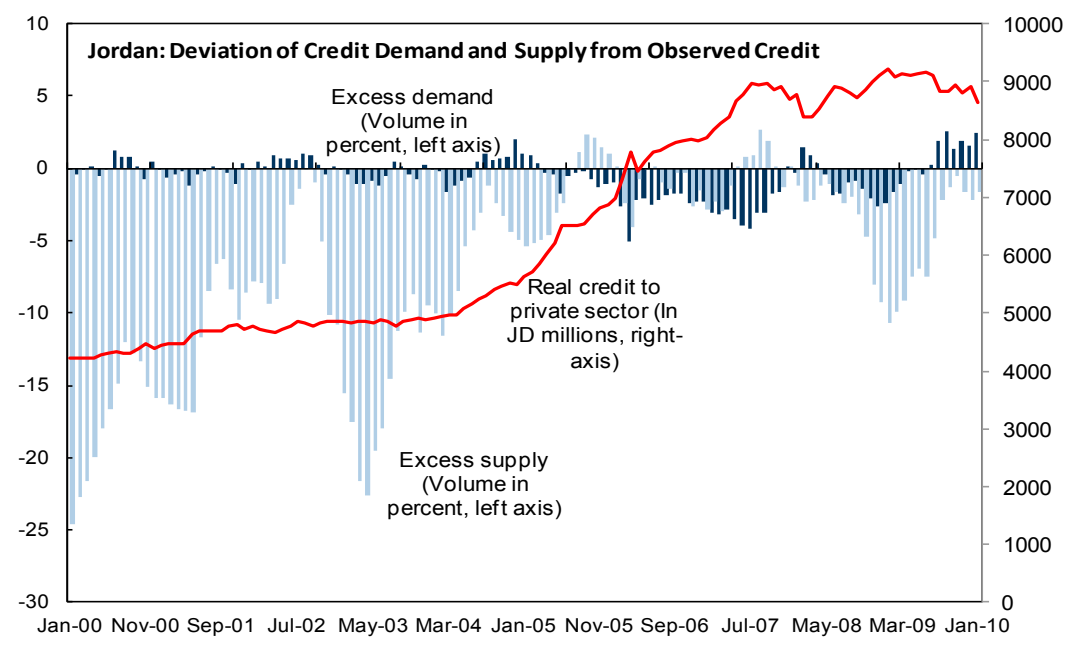

\section{Summary and policy implications}

- $\quad$ The recent slowdown in credit activity in Jordan has been mainly driven by supply factors. These include tighter lending standards exercised by banks following the global financial crisis, and a widening of the interest differential between monetary policy rates in Jordan and the United States.

- $\quad$ These results suggest that economic policies targeted towards stimulating credit supply are likely to be a more effective tool for expanding credit flows in Jordan relative to demand-stimulating policies. In particular, the monetary easing which occurred between November 2008 and February 2010, by narrowing the gap between policy rates in Jordan and the U.S., looks to have assisted in expanding the supply of bank credit. 


\section{Appendix 2. Fiscal Consolidation ${ }^{1}$}

A key policy issue is how to reduce Jordan's fiscal deficit. In 2009, the deficit including grants rose to about $81 / 2$ percent of GDP, a historic high since 1991. The 2010 budget envisages substantial fiscal consolidation. With lower projected grants receipts and the continued cyclical decline in tax revenues, consolidation will have to largely come from the spending side. This Appendix summarizes recommendations of two recent technical assistance reports by the IMF's Fiscal Affairs Department (FAD) to: (i) re-examine tax policy; and (ii) to offer advice on how to develop expenditure rationalization measures in the short and medium term in the context of declining resources.

\section{Introduction}

Since 2006, various pressures on the fiscal position have contributed to a widening of the overall deficit. High fuel and food prices also increased the pressure on spending. At the same time, the slowdown in economic activity and tax policy changes to accommodate high commodity prices weakened domestic revenue. In 2009, a stimulus to alleviate the impact of the global crisis entailed a sizable increase in capital spending. Along with a significant shortfall in external grants, the overall deficit including grants widened to around $8 \frac{1}{2}$ percent of GDP.

As a response to the worsening deficit, a tight budget was adopted for 2010 . The overall deficit is expected to narrow by over 2 percentage points of GDP to about 6 percent of GDP. This reflects greater prioritization of capital spending and savings in current expenditures, including from containment of the public sector wage bill. Supplementary revenue measures-raising indirect taxes on petroleum and other commodities, and reversing the GST exemption for coffee-will partially offset additional social expenditures on the National Aid Fund, commodity (LPG and bread) subsidies, and teachers' remuneration. With these tightening measures, the public debt-to-GDP ratio will slightly increase, but nonetheless would remain below the 60 percent legislated debt ceiling. Over the medium term, the authorities announced that their objective is to achieve a deficit target of 3 percent of GDP.

\section{Tax policy recommendations}

The revenue outlook is challenging. New positive structural changes in the revised income tax law will reduce revenue, at least in the short run, undermining the move to consolidate the fiscal accounts. Revenue from the general sales tax (effectively a VAT and the most important source of tax revenue) declined in 2009. The expansion in exemptions and zero-rated commodities, largely in response to the food and fuel price surge of 2008, undermines tax integrity, narrows the revenue base, and increases both taxpayer compliance and administrative costs. In addition, tax incentives across several different investment regimes and the continued expansion of development zones offering income and sales tax relief places income and sales tax revenue at risk.

A recent FAD review of tax revenues offered a number of recommendations designed to strengthen the tax regime. It identified steps that can be taken in the short term, and other measures that could form part of a medium-term program for tax reform.

- Short term: For the income tax, if the revenue loss from the new income tax law is too large, the government could temporarily scale back the personal allowance or introduce a tax rate surcharge. There is also potential for additional revenue from better administration, through

\footnotetext{
${ }^{1}$ Prepared by Moataz El-Said (MCD).
} 
efforts to concentrate on higher-income individuals. For the sales tax: (i) reverse the exemptions introduced in 2008, capitalizing on the opportunity given by the substantial income tax relief provided in the new income tax law; and (ii) reduce the number of sales tax rates, reverse the proliferation of zero rated transactions, and rationalize exemptions. For tax incentives, resolve the tension in investment policy between enhancing the overall investment climate and the continued expansion of targeted fiscal incentives by providing preferential treatment to specific sectors in certain geographic areas.

- Medium term: There are several options for revenue-enhancing reforms that aim at restoring tax revenues to pre-crisis levels without undermining gains in competitiveness. For the income tax, taxing capital gains would remove existing tax distortions in the treatment of capital, would improve equity, should facilitate a reduction in the high land transfer tax, and would allow treating agriculture like other sectors-while protecting low income agricultural producers. For the sales tax, enhance administration and compliance by unifying the multiple sales tax thresholds and over time, increase the unified threshold, with the introduction of a simplified turnover tax regime catching small taxpayers. For other taxes, there is scope to simplify the customs duties tariff schedule in a revenue-neutral manner. Stamp duties could be narrowed, concentrating on the main contributors to revenue. The complex property tax system, that yields little revenue, could be simplified and accompanied by improved valuation practices. Given the low corporate tax rate applied to mining, it is desirable to introduce a closer link between profitability and revenue from royalties on minerals (e.g. potash).

\section{Expenditure rationalization measures}

As noted above, envisaged fiscal consolidation will have to come largely from the spending side. Reviewing the composition of central government spending sheds light on areas large enough to have the potential to generate savings. These include wages, pensions, investment spending, transfers to government agencies, and other areas of spending. Measures outlined in a recent FAD technical assistance mission to rationalize expenditures and contain the fiscal deficit to sustainable levels over the short and medium term are summarized below.

- Wages: in the short term, to rationalize the wage bill, the authorities should: (i) adopt a full hiring freeze-including health and education; and (ii) contain wage increases through fixing wages and allowances at current nominal levels. Beyond the short term, at a minimum, conduct a review of eligibility for allowances and target them effectively. In addition, consider a review of civil service legislation, to contain costs and improve recruitment, performance incentives, and retention.

- Pensions: the budget burden of the pension system could be reduced by: (i) decreasing the contribution rate but applying it on a wider base-such as total compensation (basic wages and allowances); (ii) unifying indexation policy across all schemes as proposed for the Social Security Corporation (the lower of inflation and JD20); (iii) streamlining special category civil servants privileges; and (iv) tightening the disability eligibility criteria and requiring recertification for eligibility. Over the medium term, consider changing the accrual formula for military pensions and ensure that the SSC pension scheme is in long-term actuarial balance.

- Investment spending: the authorities should: (i) improve prioritization across sectors and analyze ongoing projects to allow for targeted cuts; (ii) review ongoing projects and acquisition decisions with a view to update and discontinue redundant ones, and decrease costs related to interest and penalties; and (iii) review the road network with the aim of building essential roads and consider a delay in the initiation of the second phase of the Amman ring road. 
- $\quad$ Transfers to government units: reducing the consolidated deficit of the current 61 government units requires structural reforms and a change in their tariff structure to achieve financial independence. Such improvements will result in efficiency gains and will eventually achieve substantial gains over the medium term. Specifically, there is a need to address the administrative losses of the Water Authority of Jordan (WAJ), with a view to achieving cost recovery through tariff restructuring, and collection improvement. In addition, review and merge units with duplicative functions, impose hard budget constraints while improving their financial autonomy, and strengthen the role of the Ministry of Finance in approving projects.

- $\quad$ Other spending: (i) social assistance—consider phasing out LPG and wheat subsidies, and revising the electricity tariff schedule to reduce the subsidy burden and limit it to low-income households through lifeline tariffs. At the same time, review National Aid Fund (NAF) eligibility criteria to improve its coverage of the poor and minimize leakage to higher-income households. (ii) education-the authorities should extend the hiring freeze to include teachers, consolidate schools and reconsider legislation to avoid building of new facilities, and expand the private sector role in training; and (iii) health-the authorities should increase public insurance premia and/or copayments, and rationalize the use of pharmaceuticals.

Savings from Alternative Expenditure Rationalization Reform Options (2010-14)

\begin{tabular}{lccccc}
\hline & 2010 & 2011 & 2012 & 2013 & 2014 \\
\hline & \multicolumn{7}{c}{ (In percent of GDP) } \\
Wages and salaries 1/ & 0.3 & 0.8 & 1.2 & 1.6 & 2.0 \\
Pensions & 0.2 & 0.3 & 0.4 & 0.4 & 0.5 \\
Investment spending 2/ & - & 0.5 & 0.3 & - & - \\
Transfers to government units & - & 0.4 & 0.3 & 0.2 & 0.2 \\
Other spending 3/ & 2.1 & 2.0 & 2.0 & 2.0 & 2.0 \\
Total & 2.6 & 4.0 & 4.2 & 4.2 & 4.6 \\
\hline
\end{tabular}

Sources: Fund staff estimates and projections.

$1 /$ Involves reducing the civil service size and reducing average compensation in real terms. 2/ Does not account for the 3 percent cut in capital spending in 2010.

3 / Savings from reforms covering education, health and social assistance. 


\section{Appendix 3. Optimal Level of International Reserves ${ }^{1}$}

Not unlike many countries in the region, in recent years Jordan's international reserve level has increased markedly, reaching $\$ 11.1$ billion as of end-2009 (equivalent to more than 8 months of imports). This Appendix analyses Jordan's international reserve dynamics based on traditional benchmarks, and the "optimal" reserve level, as well as relative to other countries in the region.

High FDI and other inflows and continued de-dollarization in the banking system have allowed Jordan's stock of reserves to almost double in the past three years. The accumulation would have been even higher had it not been for the $\$ 2.1$ billion buyback of non-concessional Paris Club debt in March 2008, which was partially financed from international reserves held by the Central Bank of Jordan (CBJ). ${ }^{2}$ The most rapid buildup in reserves-almost $\$ 5$ billion-occurred after April 2008 when the differential between the CBJ policy rate and the U.S. Federal Reserve's funds rate increased to above 200 basis points.

In the case of such an open economy as that of Jordan, holding international reserves is desirable both to deal with current and capital account shocks and to support the pegged exchange rate, which has been in place since 1950. A substantial current account deficit, a high import bill-particularly commodity related-and dependence on remittances, FDI, and other external flows make Jordan vulnerable to changes in world commodity prices and the global and regional liquidity situation. In addition, in the current global environment with heightened sovereign risk premia for emerging economies, a higher level of precautionary balances may be required to insure against adverse capital movements and to provide confidence to investors and market participants.

\begin{tabular}{lcccccc}
\hline & $1996-2000$ & $2001-05$ & 2006 & 2007 & 2008 & $\begin{array}{c}2009 \\
\text { Prel. }\end{array}$ \\
\hline In months of prospective imports of goods and services & 3.9 & 5.7 & 5.1 & 4.7 & 6.2 & 8.1 \\
In percent of & & & & & & \\
GDP & 21 & 38 & 41 & 40 & 34 & 44 \\
Broad money & 18 & 30 & 31 & 31 & 30 & 39 \\
Total deposits & 22 & 35 & 36 & 36 & 35 & 45 \\
External debt & 23 & 55 & 83 & 93 & 151 & 203 \\
Ratio to & & & & & & \\
ST debt by remaining maturity & 4.4 & 4.8 & 7.3 & 7.9 & 11.6 & 18.4 \\
FX deposits & 1.0 & 1.2 & 1.3 & 1.3 & 1.6 & 2.7 \\
Remittances & 1.1 & 2.0 & 2.4 & 2.3 & 2.4 & 3.6 \\
$\quad$ Tourism receipts & 2.2 & 3.7 & 3.0 & 3.0 & 2.6 & 3.8 \\
Grants & 4.2 & 5.1 & 7.2 & 18.1 & 5.8 & 11.3 \\
Oil and food imports & 1.3 & 2.1 & 1.6 & 1.5 & 1.4 & 2.6 \\
FDI & 7.9 & 9.0 & 1.8 & 3.6 & 2.7 & 4.7 \\
Memorandum item: & & & & & & 11.1 \\
$\quad$ International reserves (\$ billion) & 1.7 & 4.1 & 6.1 & 6.9 & 7.7 & \\
\hline
\end{tabular}

Sources: Central Bank of Jordan and Fund staff estimates.

\footnotetext{
${ }^{1}$ Prepared by Anna Ter-Martirosyan (MCD).

${ }^{2}$ The buyback was financed by a land sale (about $\$ 500$ million) and the proceeds from the government's privatization accounts (about $\$ 1.6$ billion). The latter was reflected in a drawdown of foreign reserves.
} 
Jordan's foreign reserve coverage has been comfortable in recent years, based on traditional reserve adequacy measures such as import coverage, and ratios to GDP, external debt, and the money stock. It has improved further in 2009 covering more than eight months of prospective imports and 200 percent of external debt. Based on the latest data, Jordan also compares favorably with other countries in the region.

Reserve Benchmark Indicators, 2009
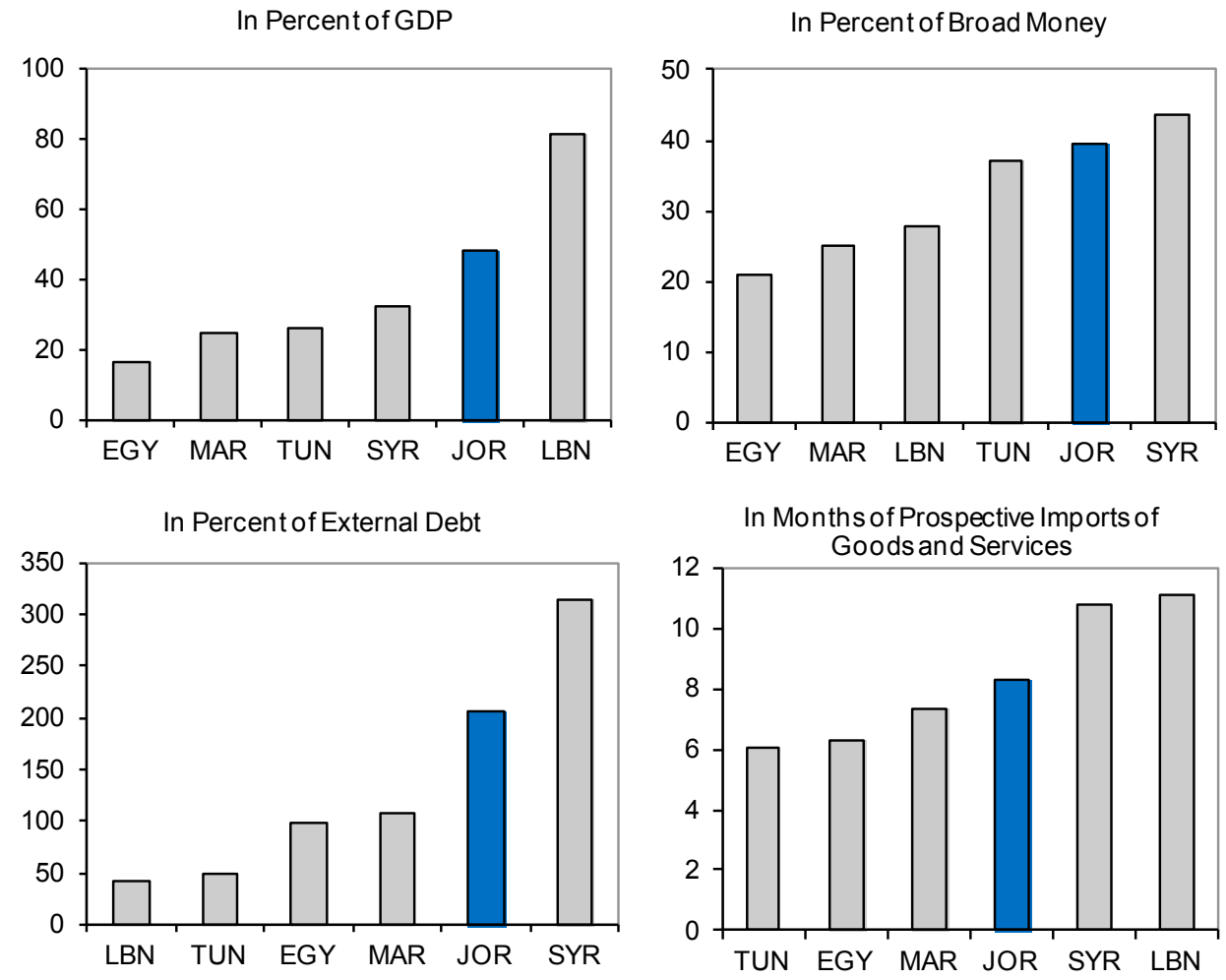

A comparison of actual reserve holdings relative to the optimal reserve level required to withstand various shocks confirms that Jordan's international reserves are above the optimal range: ${ }^{3}$

- Current account shocks. The level of optimal reserves sufficient to withstand current account shocks-expressed in months of imports or as a substantial decline in remittances, grants and other external inflows-has been consistently below the actual level of reserves for the last several years. ${ }^{4}$

- Capital account shocks. Starting from 2005, actual international reserves became more than sufficient to cover short-term capital outflows (short term external debt and foreign currency

\footnotetext{
${ }^{3}$ Based on the methodology proposed by O. Jeanne, 2007: "International Reserves in Emerging Market Countries: Too Much of a Good Thing?" Brookings Papers on Economic Activity, Vol. 1, pp. 1-79.

${ }^{4}$ Although the results are somewhat sensitive to the calibration parameters, they still hold for the basic sensitivity analysis, including increasing the output loss to 13 percent of GDP (equivalent to the effect of the 1989 economic crisis for Jordan).
} 
deposits), with the gap between the actual and optimal reserve levels widening considerably in the last two years.

- Financial crisis. Recent reserve accumulation has also made actual reserves sufficient to withstand potentially very large deposit outflows. In particular, an optimal level of reserves for a shock equivalent to withdrawal of 40 percent of banking system deposits (as was observed in Uruguay in 2002) is below the actual level of reserves for 2009.

\section{Optimal Level of Reserves Given Different Types of Shocks \\ (In percent of GDP)}
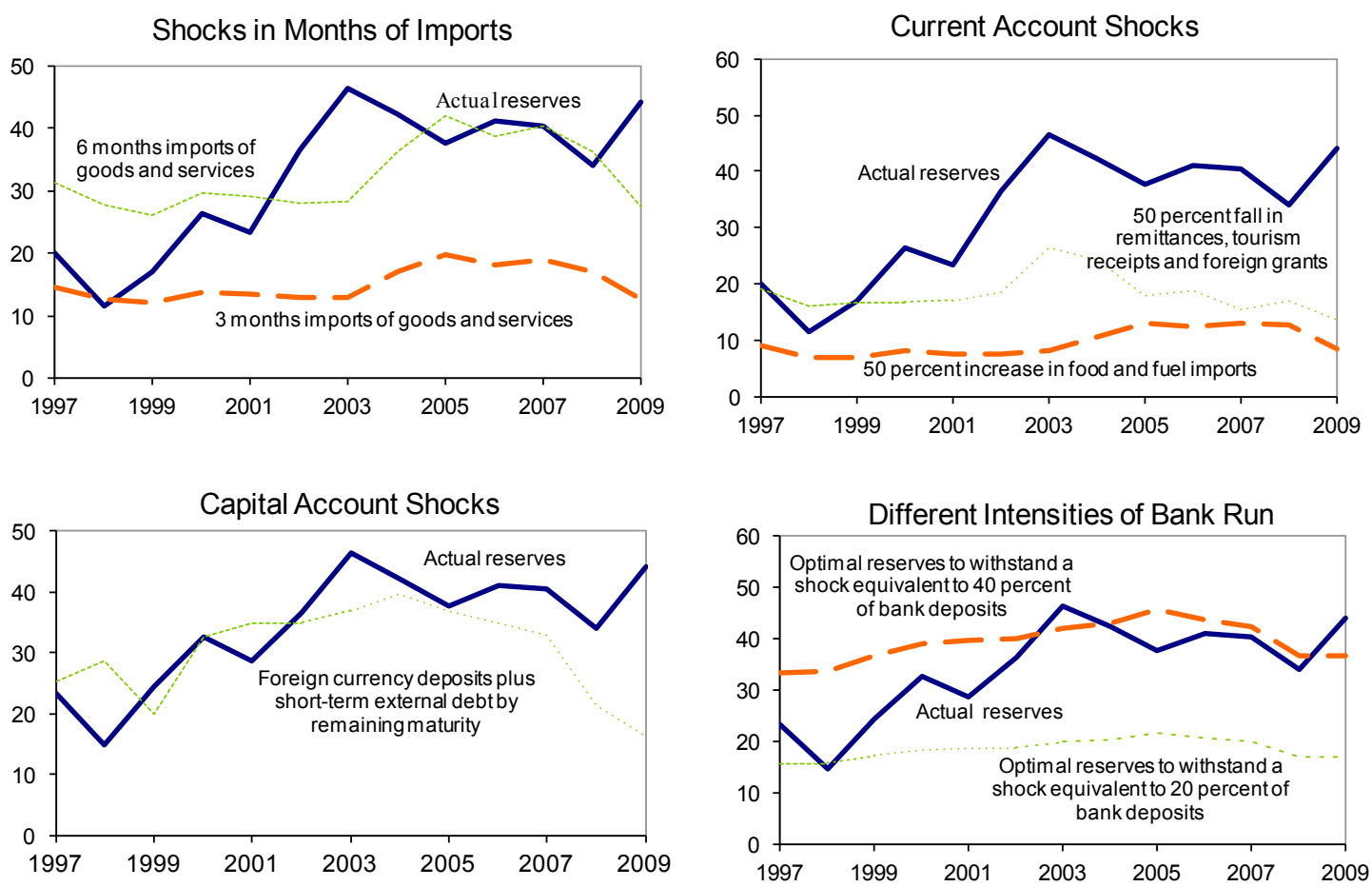

Extending the same methodology to other countries in the region confirms a general preference for higher reserve holdings for economies in the Mashreq/Maghreb regions. ${ }^{5}$ Most of the countries hold higher reserves than the optimal level predicted by the Jeanne (2007) model, and the "excess reserve" holdings-equal to the difference between the actual and optimal reserve levels-have generally increased between 2000 and 2009, pointing to potentially higher demand for precautionary balances in a more open external environment.

\footnotetext{
${ }^{5}$ See A. Ter-Martirosyan and T. Poghosyan, forthcoming, "Assessing International Reserve Adequacy in Jordan Using Two Alternative Approaches," IMF Working Paper.
} 
Optimal Reserve Levels (2000 and 2009) $1 /$

(In percent of GDP)
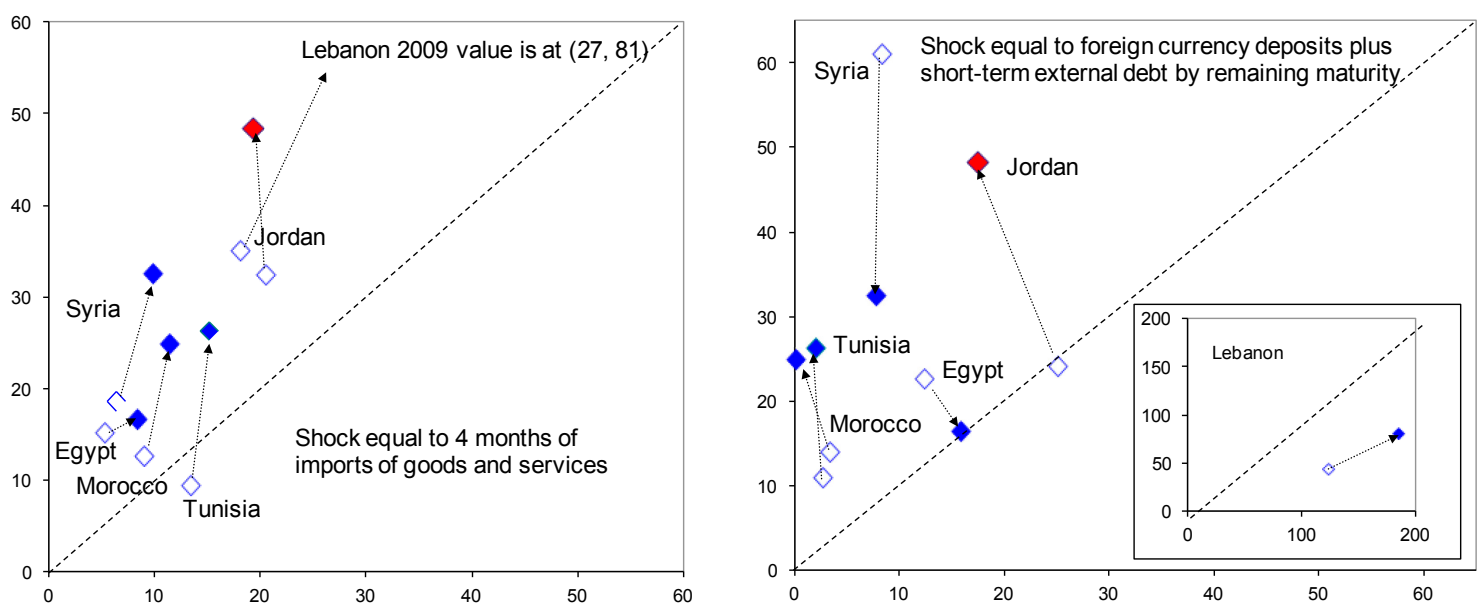

$1 /$ The dashed line corresponds to actual reserves equal to the optimum level. Observations above the dashed line indicate that the actual reserve holdings exceed the optimal level. Observations for 2000 are marked with the empty diamond, and for 2009 with the solid diamond.

To conclude, the current level of foreign reserves is sufficient to cover severe potential capital and current account shocks, and ranks Jordan higher than most comparator countries in the region based on both traditional reserve adequacy measures and some benchmarks for optimal reserve holdings. This comfortable reserve position-relative to both potential stocks and to other economies in the region-provides a substantial cushion against potential risks, makes the economy less vulnerable to future fluctuations in the level of international reserves, and allows more flexibility for the future conduct of monetary policy in a challenging global environment. 


\section{Appendix 4. Interest Margin Determinants in the Jordanian Banking System ${ }^{1}$}

This Appendix examines the determinants of the interest margin in Jordan by decomposing it into its profit and cost components, including reserve requirement costs, operational costs, and provision for loan losses. The net interest margin, measured as the difference between lending and deposit rates, is a commonly-accepted measure of bank intermediation costs. The importance of the bank interest margin as a measure of financial intermediation costs is particularly pronounced in emerging economies, including Jordan, where in the absence of highly-developed stock markets firms are largely dependent on bank financing as a source of external funding.

The trajectory of the interest margin in Jordan displays diverging dynamics (Figure 1). The margin between lending and time deposit rates increased from $4 \frac{1}{2}$ percent at the beginning of 2000 to $6 \frac{1}{2}$ percent in mid-2003, then declined to 3 percent in mid-2006, and then has risen again to reach $41 / 2$ percent at the end of 2009 . The increase has been particularly sharp during the past year, in the aftermath of the global financial crisis. The margin between lending and saving deposit rates is larger in magnitude, but has similar dynamics.

Figure 1. Jordan: Dynamics of Interest Margin

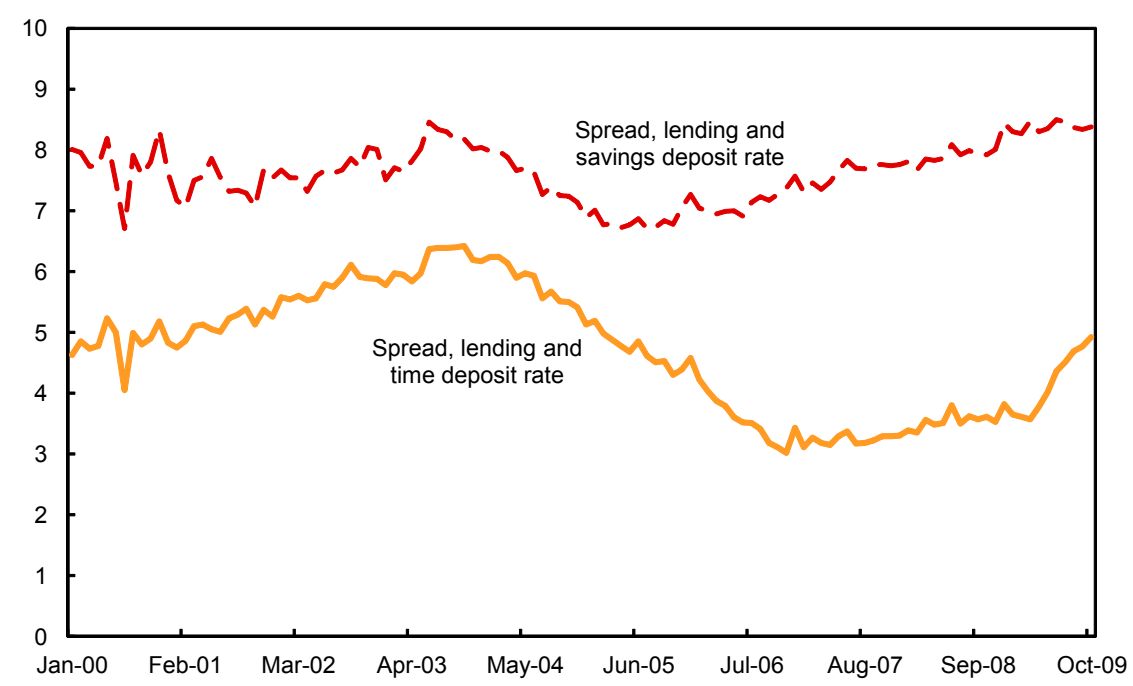

The interest margin decomposition is based on the methodology proposed in Randall (1998). ${ }^{2}$ The income statement of banks defines profits before taxes $(P)$ as interest income $(I I)$, plus non-interest income $(N I I)$, minus interest expense $(I P)$, minus operating costs $(O C)$, and minus provision for loan losses (Prov). After rearranging this identity, the net interest revenue can be expressed as:

$$
I I-I P=O C+\text { Prov }+P-N I I .
$$

\footnotetext{
${ }^{1}$ Prepared by Tigran Poghosyan (MCD).

${ }^{2}$ Randall, R., 1998, "Interest Rate Spreads in the Eastern Caribbean," IMF Working Paper 98/59 (Washington: International Monetary Fund).
} 
Dividing this expression by the interest bearing liabilities (average deposits) $(D)$ and using average interest bearing assets $(L)$ and total assets $(A)$, the following expression can be obtained:

$$
\frac{I I}{L} * \frac{L}{D}-\frac{I P}{D}=\frac{O C}{D}+\frac{\operatorname{Pr} o v}{D}+\frac{P}{A} * \frac{A}{D}-\frac{N I I}{D}
$$

Assuming that banks invest one minus the required reserve ratio $(\rho)$ component of their interest bearing liabilities into interest bearing assets $(L / D=(1-\rho))$, and defining the interest margin as the difference between the implicit lending rate $\left(I I / L=i_{L}\right)$ and implicit deposit rate $\left(I P / D=i_{D}\right)$, the above expression can be written as:

$$
i_{L}-i_{D}=\rho * i_{L}+\frac{O C}{D}+\frac{\operatorname{Pr} o v}{D}+R O A * \frac{A}{D}-\frac{N I I}{D}+\varepsilon
$$

where $R O A=P / A$ denotes bank profitability (gross return on assets), and the error term $\varepsilon$ results from combining flow (income statement) and stock (balance sheet) data, as well as making the simplifying assumption about the reserve requirement holdings by banks. The above expression decomposes the margin into the following cost and profit components: reserve requirement costs $\left(\rho^{*} i_{L}\right)$, operational costs $(O C / D)$, loan loss provision costs (Prov/D), profitability $\left(R O A^{*} A / D\right)$, and non-interest income (NII/D, with negative sign).

To decompose the interest rate margin, we use semi-annual data on consolidated balance sheets and income statements of the Jordanian banking industry for the period 2003-09, as provided by the Central Bank of Jordan. Figure 2 displays the implicit interest margin and its components for the analyzed period. Several conclusions can be drawn from the results contained in Figure 2.

Figure 2. Jordan: Decomposition of Interest Margin in Cost and Profit Components

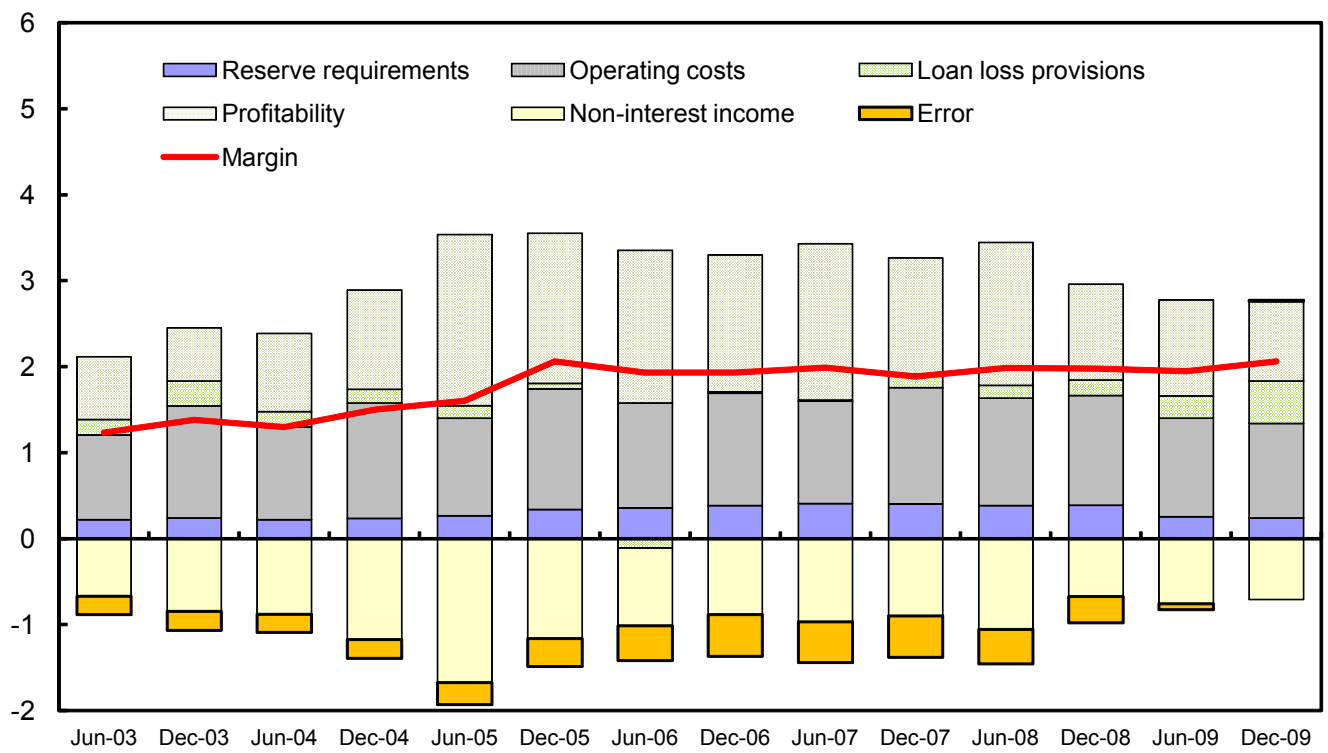


First, the implicit interest margin is much smaller (in the neighborhood of 1-2 percentage points) than the simple difference between lending and deposit rates presented in Figure 1. This difference is mainly driven by the negative effect of the non-interest component of bank earnings and lower interest revenue on interbank deposits (counted as interest-bearing assets in the former measure).

Second, profits constitute a substantial portion of the margin. Banks in emerging market countries like Jordan need to generate sufficient profit to compensate for the risk undertaken in a relatively less stable economic environment than that found in advanced countries. However, the share of profits has been declining over time, especially following the global financial crisis. Interestingly, bank profitability decreased and the margin slightly rose following the increase in loan-loss provisioning in 2008-09. This implies that part of the additional costs associated with the deterioration of banks' loan portfolios were passed through to bank clients by an increase in the interest margin, while the remaining costs were incurred by banks themselves in terms of lower profitability.

Third, related to the previous point, the share of loan-loss provision costs in the margin has risen in the aftermath of the global financial crisis. Since the crisis is not over as yet, it is possible that banks will attempt to pass through the loan loss provision costs in the coming months, in which case the interest margin might increase further. Forthcoming data on the first part of 2010 will help to clarify this point.

Fourth, the share of operating costs in the margin has been broadly constant over time. These include personnel costs, among other components, and can be considered as a proxy for the efficiency of banking intermediation in Jordan. The relatively large share of this component in the margin implies that there is potential room for further reduction in the interest margin that may arise from an increase in the efficiency of banking operations.

Fifth, reserve requirement costs have been reduced following the decline of the reserve requirement ratio from 10 to 7 percent of deposits in the second half of 2009. Overall, the share of this component is not very large, given the relatively low reserve requirement ratio in Jordan.

Finally, Figure 2 suggests that the interest margin is substantially reduced due to the ability of banks to generate income from non-interest sources, such as fees and service charges. However, the magnitude of non-interest sources of income has progressively declined from mid-2005 onwards.

To conclude, the analysis in this Appendix suggests that operational costs constitute a large share of the margin, implying the existence of room for its further reduction due to improvements in the efficiency of financial intermediation. The bank profitability component of the margin has been declining over time, especially following the increase in loan loss provisions in the wake of the global financial crisis. The recent reduction in the reserve requirement ratio has decreased its share of costs in the margin.

The above analysis provides the following policy implications:

- $\quad$ the reserve requirement ratio can be used as a tool by the Jordanian monetary authorities to influence the magnitude of the interest margin; and

- $\quad$ the recent build up of non-performing loans by banks may be passed through to their customers through an increase in the interest margin. 


\section{Appendix 5. FSAP Recommendations and Banking Supervision Reforms ${ }^{1}$}

The Central Bank of Jordan (CBJ) has undertaken significant reforms to enhance its banking supervision, in line with the recommendations of the 2008 Financial Sector Assessment Program (FSAP) Update. This Appendix provides a summary of the main reforms. These include: (i) ongoing efforts to ensure compliance of banks with Basel II principles; (ii) requiring semi-annual bottom-up stress testing of banks, examining in particular credit risk and concentration risk; (iii) reporting the aggregate results of stress tests in the CBJ's annual Financial Stability Report; (iv) introducing an automated data collection system to improve off-site monitoring of banks; (v) enhanced cross-border bank regulation through regular supervision and on-site inspections of international branches and subsidiaries of Jordanian banks; (vi) improvements to its early warning system; and (vii) improving access to finance by expanding the public credit registry and passage of a private credit bureau law.

Basel II implementation. The CBJ has now issued all the regulations for Basel II implementation. The regulations for Pillars I and III were issued in 2008. The Pillar II regulations were issued in February 2010. The banks are in the process of applying these regulations.

Stress testing. The bottom-up stress testing exercise, as part of Pillar II, is underway. The CBJ issued stress testing regulations in September 2009 and requested banks to run stress tests based on a number of standard scenarios related to different types of risks (especially credit risk and concentration risk). The CBJ also requested banks to identify some additional scenarios taking into consideration the risk profile of each bank. The CBJ is finalizing the validation process of the stress tests conducted by banks, and will work on reflecting regular stress tests in CAMELS scoring.

Financial Stability Report. The third Financial Stability Report was published in 2009. The CBJ will draw on the main findings of the bottom-up stress tests and report their results in forthcoming reports.

Automated data collection system. The CBJ is working towards finalizing the development of a comprehensive and automated database, possibly by year-end, to help in strengthening banking supervision and enhance the Early Warning System.

Enhanced cross-border regulation. In order to strengthen global consolidated supervision, the CBJ has performed on-site cross-border examinations on complex groups. The CBJ visited Arab Bank/London, Arab Bank/Switzerland and branches of three Jordanian banks operating in Cyprus. In 2010 the CBJ will visit branches of banks operating in the Gulf area (Qatar and UAE). The CBJ plans to continue visiting Jordanian banks with a material presence abroad. Banks with branches in Palestine already provide monthly reports to the CBJ.

Early Warning System. The CBJ has continued to monitor financial soundness indicators on a semi-annual basis, and is working on improving the Early Warning System by developing a statistical model to be used as an early warning system, in addition to the two approaches that are already being used (Financial Ratio Analysis and Peer Group Analysis and CAMEL).

Improving access to finance. The CBJ has lowered the threshold for the public credit registry from JD 30,000 to JD 20,000. In the meantime, a private credit bureau law has been approved. The CBJ is working towards drafting the regulations and by-laws, with technical assistance from the Middle East Technical Assistance Center (METAC).

\footnotetext{
${ }^{1}$ Prepared by Serkan Arslanalp (MCM).
} 
Short term

- Strengthen the CARs of the vulnerable banks through the supervisory process and not by increasing the minimum nominal amount of capital required for entry.

- Strengthen global consolidated supervision, and perform onsite crossborder examinations on complex groups.

- Prepare contingency plans to deal with stress in the banking system.

- Continue to strengthen monitoring of financial soundness indicators (FSIs) and build early warning systems

- Strengthen the staffing of the supervisory department of the CBJ.

- Enhance monitoring of broker-dealers and introduce procedures for early intervention.

- Lower the threshold for the public credit registry to cover the overwhelming majority of credits, and disclose the full credit history and the borrower's rating from other banks to prospective lenders.

- Streamline government's cash management and publish issuance calendars.
The CBJ issued Pillar II guidelines in February 2010 and requested banks to submit their capital plans by the end of June 2010 and the Internal Capital Adequacy Process (ICAAP) by the end of 2010. CBJ will conduct the Supervisory Review and Evaluation Process (SREP) on the submitted ICAAPs to ensure that banks have adequate risk management systems consistent with the size, nature, and complexity of their operations and to ensure that banks have adequate capital against all their material risks, so CBJ will take the required actions-if needed-to strengthen CARs of the vulnerable banks based on the results of the SREP. The minimum nominal amount of capital required for entry has remained constant.

The CBJ visited Arab Bank/London, Arab Bank/Switzerland and branches of three Jordanian banks operating in Cyprus. They are about to visit branches of banks operating in the Gulf area (Qatar and $U A E$ ). They plan to continue visiting material presence of the Jordanian banks abroad. They also continue to receive monthly reports from banks with branches in Palestine.

The CBJ has a prompt corrective action framework to deal with any weaknesses or breaches of laws and regulations at an early stage, in addition to the tools available for CBJ by laws and regulations to deal with stress in the banking system. These are seem to be broadly sufficient and, as such, the CBJ does not have a formal contingency plan in this regard.

The CBJ monitors financial soundness indicators on a semi-annual basis, and is working on improving the Early Warning System adopted by CBJ towards developing a statistical model to be used as an early warning system, in addition to the two approaches that are already being used (Financial Ratio Analysis and Peer Group Analysis and CAMEL). The CBJ is working towards finalizing the development of a comprehensive and automated database, possibly by year-end, to help in strengthening banking supervision and enhancing the Early Warning System.

The Banking supervision department has hired a number of fresh graduates and some experience personnel. There are currently 80 staff in the department (end-June 2010).

The threshold for the public credit registry was lowered from JD30,000 to JD 20,000. Under the new threshold, the public credit registry covers about 80 percent of credits

Work in progress. The government is considering to publish auction calendars (on a quarterly basis), starting in 2011. 
Medium term

- Recapitalize the central bank.

- Develop explicit exit procedures both for dealing with unsound banks and to make room for a more open entry policy consistent with greater contestability in the system.

In CBJ's view, the CBJ already has licensing criteria issued to banks to deal with entry policy and CBJ regulations are sufficient to deal with entry and exit procedures.

- Enhance the stress testing capacity of the CBJ and commercial banks, focusing in particular on credit risk. Reflect regular stress tests in CAMELS scoring.

The CBJ issued stress testing regulations in September 2009, in order to measure the ability of the banks to withstand a range of severe but plausible shocks, and requested banks to run stress tests based on a number of standard scenarios related to the different types of risks (especially credit risk and concentration risk). The CBJ also requested banks to identify some additional scenarios taking into consideration the risk profile of each bank. After finalizing the validation process of the stress tests conducted by banks, the CBJ will work on reflecting regular stress tests in CAMELS scoring. They have also conducted training courses on stress testing for CBJ and banks' staff.

- Pass the draft insurance law, which will improve the governance of the Insurance Commission and its independence from government.

- Introduce legislation on mutual funds.

- Restructure the motor third party liability insurance.

- Introduce financial literacy training and regulations for households.

1/ Jordan-Financial System Stability Assessment-Update (April 2009)--Box 1

2/ As of end-June 2010 
- Enhance CAMEL (toward CAMELS and, after, CAMELS2) and increase the frequency of update of the ratings (at least once a year, if possible twice a year for all banks or for the systemic and more risky banks).

- For the operational risks also offer the second approach (the TSA) to selected banks. Start collecting the data in 2009.

- Define the right definition of default.

- Select the possible "selected" candidate banks for a move towards FIRB \& TSA and gain consensus on this choice.

- Ask those banks to start collecting the Basel II IRB variables compliant with the right definition of default.

- Change the agenda for the possible first implementation of the Basel This is under consideration. II FIRB Foundation IRB (2014) and prepare some day for the AIRB.

- Modify accordingly with the definition of default, some texts (provisioning, PCA etc.). Please also see the proposal made in the $\mathrm{BCP}$ (connected lending, large exposures, etc.).

- Establish your philosophy regarding the Pillar 2: SREP (how far and deep?), ICAAP (and economic capital; what use and control?), possible target ratio.

- Decide on the validation process and communication to the banking Industry of the agenda, road map and validation process. Train the adequate BSD personnel to "validate" the FIRB models at advanced banks. (What "validate" means in your supervisory and legal environment?).

- Adopt and adapt COREP and FINREP for your reporting (and for disclosure under Pillar 3 ).

- Prepare a move towards a more risk-based approach.
The CBJ is working on developing a comprehensive report containing the most important quantitative and qualitative information for each bank, and this report will be used to assess the risk profile of the bank and to enhance CAMEL Rating.

This approach is already offered to banks that can meet the minimum requirements, and some banks are working on these requirements.

This will be done through the preparation of moving banks to the more advanced approached.

Some banks (especially large banks) are working on building the required infrastructure for moving to the more advanced approaches.

The CBJ will review the readiness of banks (especially large banks) to start collecting Basel II IRB variables through conducting (SREP) and their (ICAAPs).

This will be done through the preparation of moving banks to the more advanced approached.

The CBJ issued Pillar II guidelines and requested banks to submit their capital plans by the end of June 2010 and the Internal Capital Adequacy Process/ICAAP by the end of 2010. CBJ will conduct the Supervisory Review and Evaluation Process (SREP) on the submitted ICAAPs to ensure that banks have adequate risk management systems consistent with the size, nature, and complexity of their operations and to ensure that banks have adequate capital against all their material risks.

The CBJ is working on upgrading its personnel qualifications and skills and building the required environment to move to the more advanced approaches.

The CBJ is working towards finalizing the development of a comprehensive and automated database to help in strengthening banking supervision and enhancing the Early Warning System and developing a risk profile report for each bank.

This comes in line with the effective implementation of Pillar II.

1/ Jordan-Technical Note, Factual Update of the Basel Core Principles for Effective Banking Supervision and Analysis of Basel II Implementations (Section IV).

2/ As of end-June 2010. 


\section{Appendix 6. Debt Sustainability Analysis ${ }^{1}$}

\section{A. Public Debt Sustainability Analysis}

\section{As a result of the implementation of fiscal consolidation measures in 2010 and the} medium term, Jordan's public debt is expected to decline to around 53 percent of GDP in $2015 .^{2}$ Following a steady decline in 2003-08 the debt ratio increased by about 3 percentage points in 2009 due to a substantial widening of the fiscal deficit caused by a moderate fiscal stimulus, cyclical decline in revenues, and a shortfall in external grants. Based on the 2010 budget and assuming that fiscal consolidation measures will continue over the medium term, the debt ratio is projected to increase slightly in 2010-11 and then decline by about one percentage point per year over the medium term.

The debt outlook remains vulnerable to adverse shocks. Standard bound tests reveal the following (Figure A.1):

- A contingent liabilities shock-an increase in the debt ratio by 10 percent of GDP in 2010would cause the debt path to remain about 10 percentage points above the baseline throughout the projection period.

- As about one third of the debt is foreign-currency denominated, a 30 percent real exchange rate depreciation would increase the debt-to-GDP ratio by around 10 percentage points relative to the baseline in 2010 .

- $\quad$ Even under smaller shocks -individual one-half standard deviation shocks to real growth, interest rates, and the primary balance-the debt-to-GDP ratios would exceed 60 percent by the end of the projection period.

Public debt sustainability and containing these vulnerabilities is contingent on appropriate adjustment policies. Under the baseline outlook, the average primary deficit (including grants) declines from about 4 percent of GDP in 2010 to 0.6 percent by 2015. In contrast,

- $\quad$ holding the primary deficit constant at 6.3 percent of GDP (its 2009 level) over 2010-15 would cause the debt ratio to grow to 85 percent by 2015 ;

- $\quad$ the debt ratio would decline (approaching 42 percent by 2015) if key assumptions are held at their historical averages, reflecting that the primary deficit (including grants) was, on average, below one percent of GDP in 2000-09.

\footnotetext{
${ }^{1}$ Prepared by Hirut Wolde (MCD).

${ }^{2}$ Public debt is defined as government and government-guaranteed debt. The domestic component is net of government deposits with the banking system, including privatization proceeds.
} 


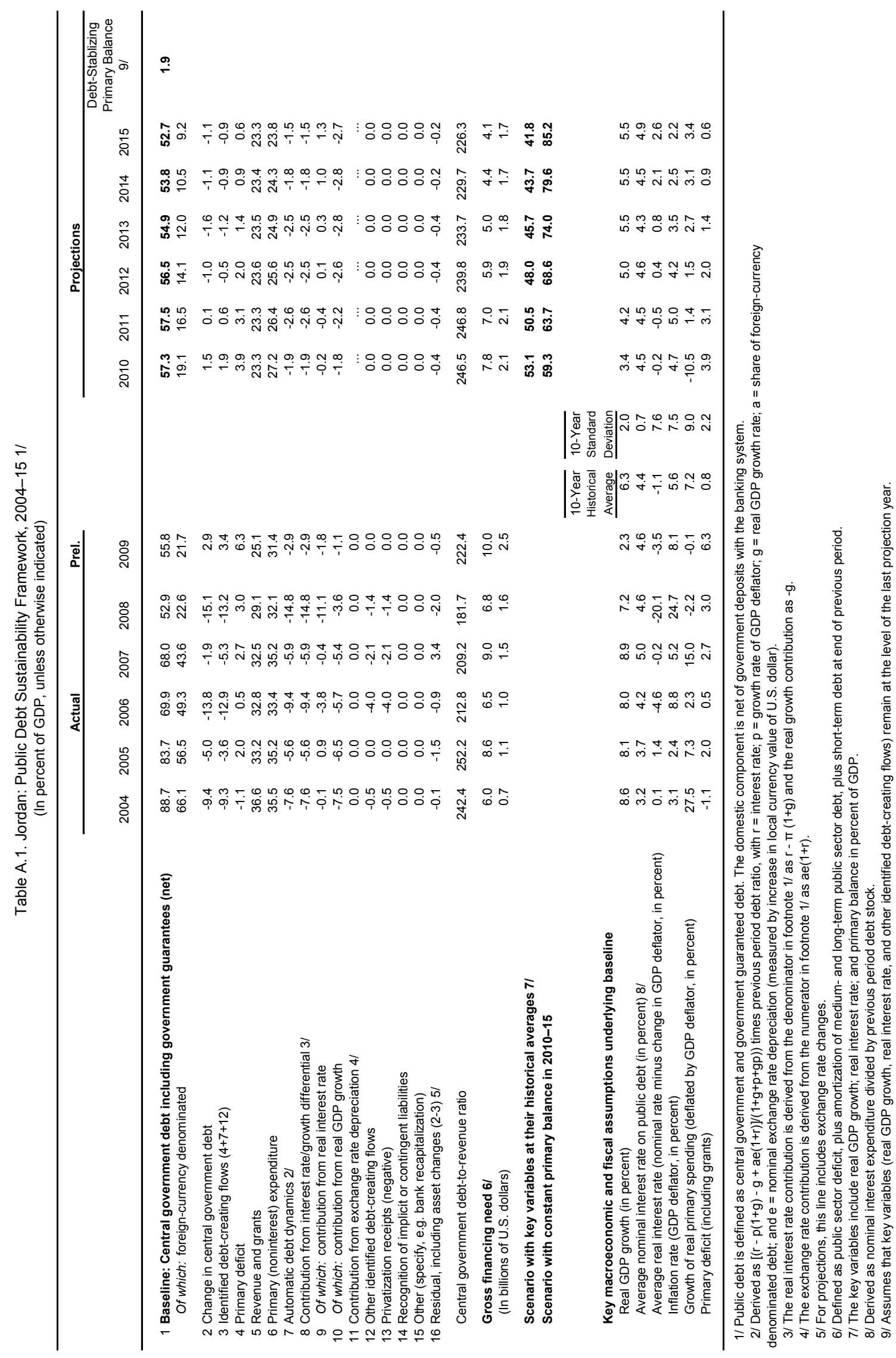


Figure A.1. Jordan: Public Debt Sustainability: Bound Tests 1/2/ (In percent of GDP)
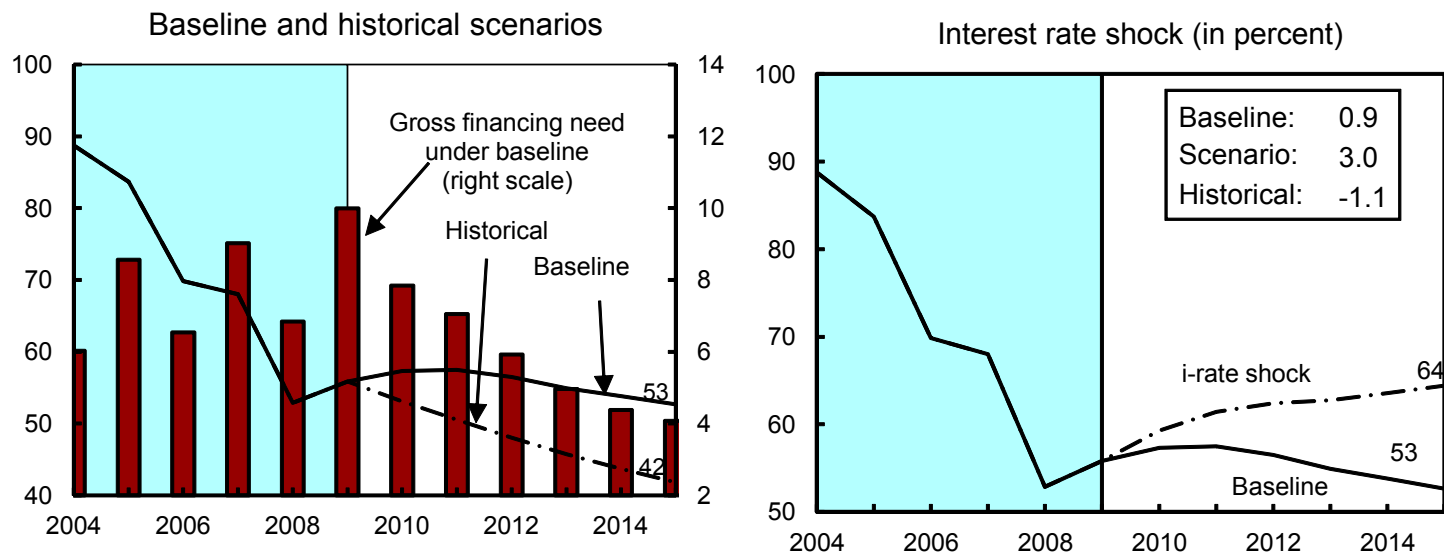

Growth shock (in percent per year)

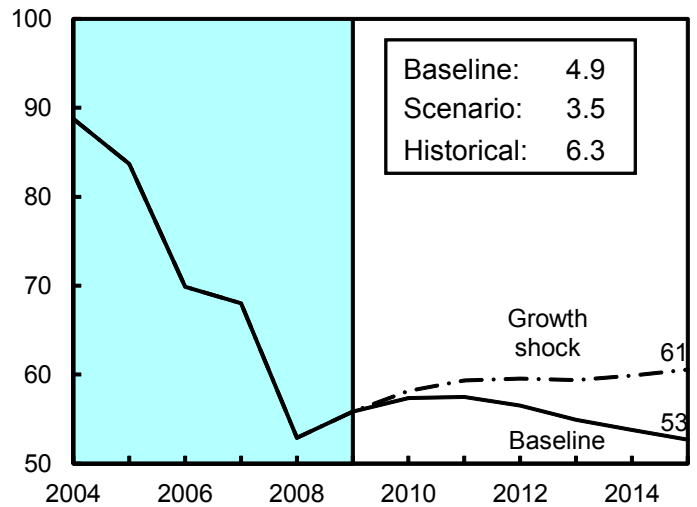

Primary balance shock (in percent of GDP) and constant primary balance (in percent of GDP)

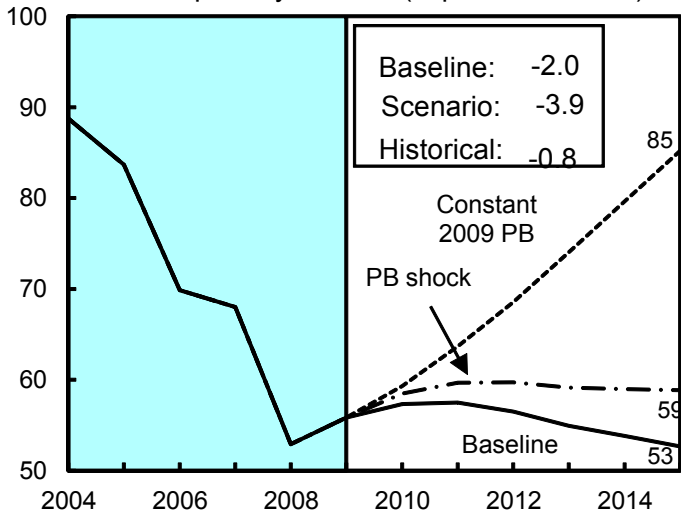

Real depreciation and contingent liabilities shocks 4/
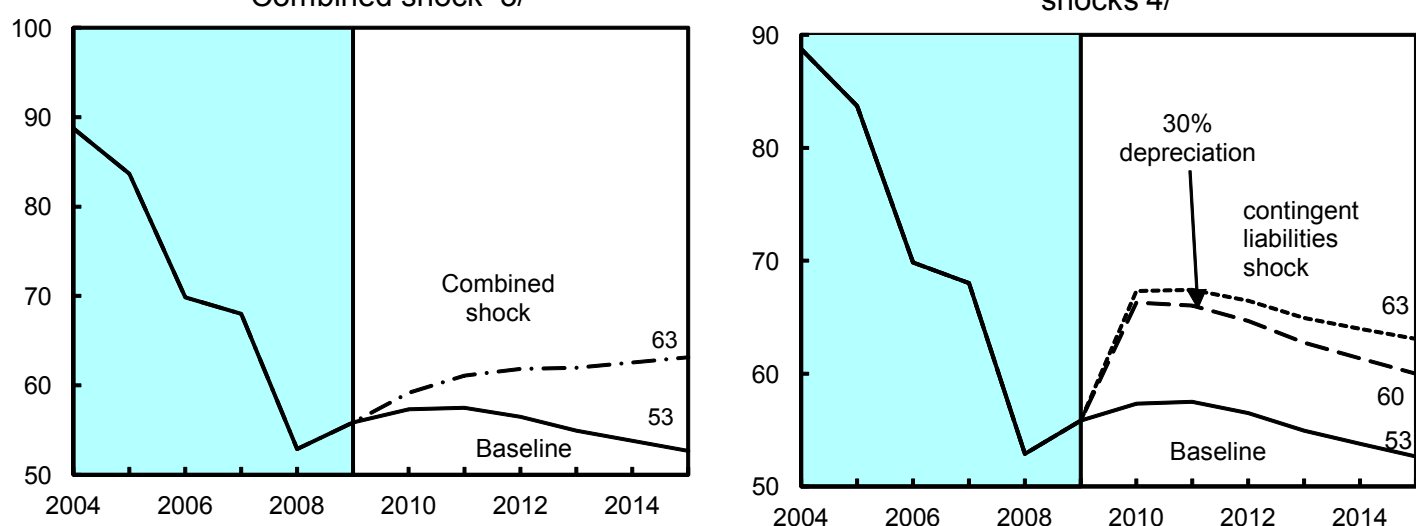

Sources: Jordanian authorities; and Fund staff estimates.

$1 /$ Public debt is defined as central government debt and government guaranteed debt. The domestic component is net of government deposits with the banking system.

$2 /$ Shaded areas represent actual data. Individual shocks are permanent $1 / 2$ standard deviation shocks. Figures in the boxes represent average projections for the respective variables in the baseline and scenario being presented. The end-period values are also shown.

3/ Permanent 1/4 standard deviation shocks applied to real interest rate, growth rate, and primary balance.

4/ One-time real depreciation of 30 percent and 10 percent of GDP shock to contingent liabilities occur in 2010. 


\section{B. External Debt Sustainability Analysis}

Jordan's external debt is relatively low but remains vulnerable to adverse shocks. The external debt ratio declined sharply to 25 percent of GDP following the $\$ 2.1$ billion buyback of Paris club debt in 2008 and is expected to fall below 20 percent by end-2010. The projections are based on the current outlook for commodity prices-particularly for food and fuel-and expectations that Jordan will continue to pursue cautious external borrowing policies, relying predominantly on concessional sources of external financing from multilateral and regional development banks.

The envisaged debt path is somewhat sensitive to assumptions regarding current account flows and the outlook for private capital flows (Figure A.2):

- $\quad$ The standard bound tests reveal that external debt sustainability is most vulnerable to developments in the current account position. If the actual current account were one-half standard deviation worse than currently assumed, the debt ratio would edge up throughout the projection period (reaching 23 percent of GDP by 2015).

- An important source of risk is a sharper slowdown in current account inflows and FDI if the global/regional downturn proves deeper than currently expected. An impact of such a slowdown is illustrated in an alternative scenario that envisages a 20 percent decline in 2010-11 in remittances and tourism flows, as well as FDI, relative to the baseline. ${ }^{3}$ Under this scenario, the debt ratio deteriorates to about 28 percent by end-2011.

- $\quad$ Bound tests show that the debt-to-GDP ratio is robust to shocks in the external interest rate or GDP growth. A sharp depreciation would lead to an immediate deterioration in the debt ratio but would not have a major adverse impact over time because of the relatively low stock of projected external debt.

\footnotetext{
${ }^{3}$ The total impact of the shock is likely overstated, since imports are assumed to be unaffected by the decline in inflows.
} 


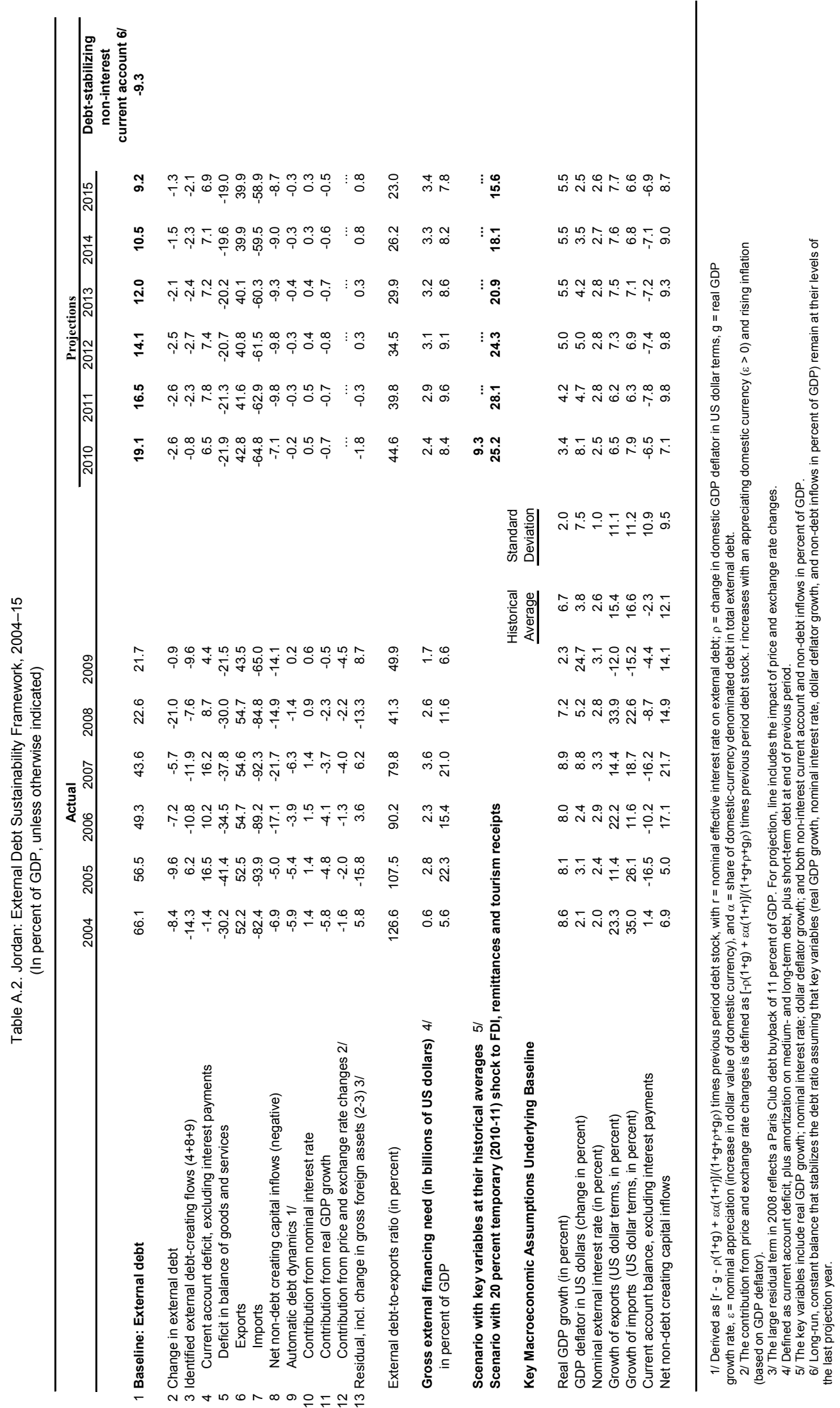


Figure A.2. Jordan: External Debt Sustainability: Bound Tests 1/ (In percent of GDP)
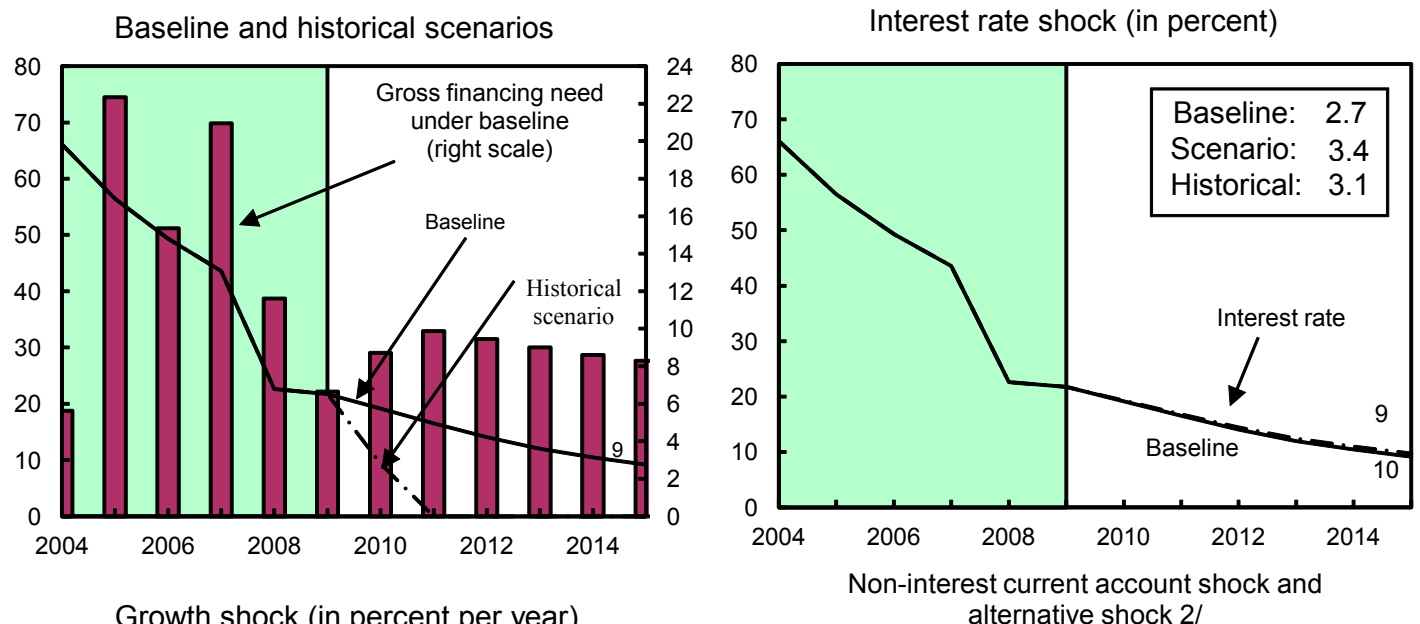

Growth shock (in percent per year)
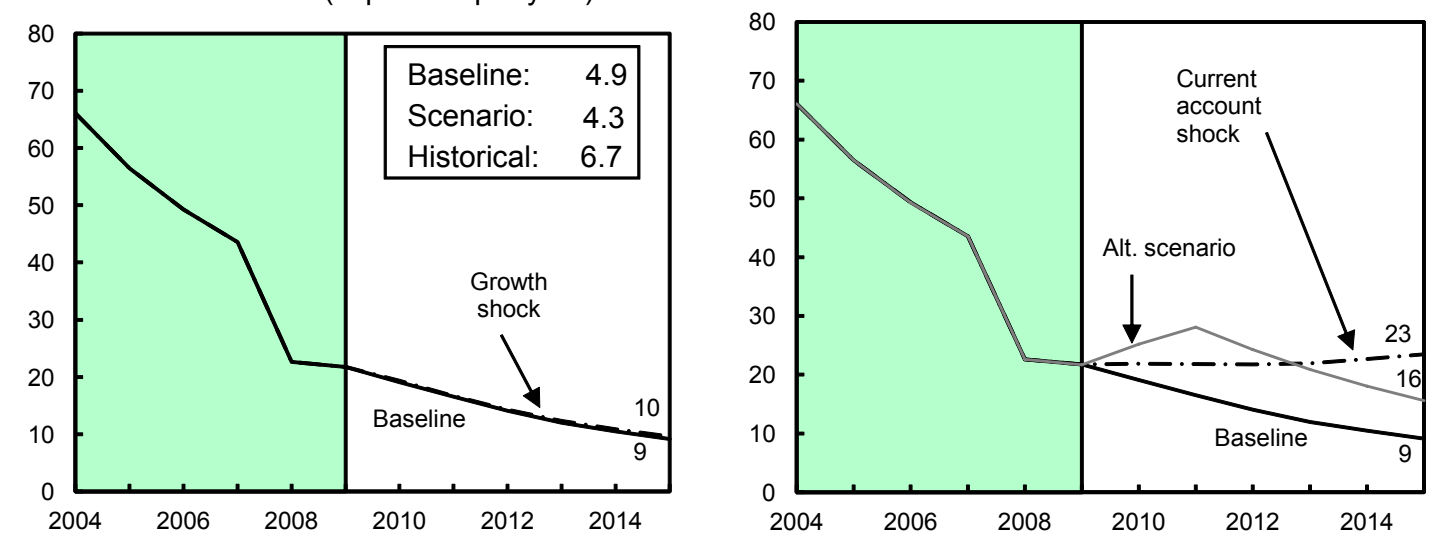

Combined shock $3 /$
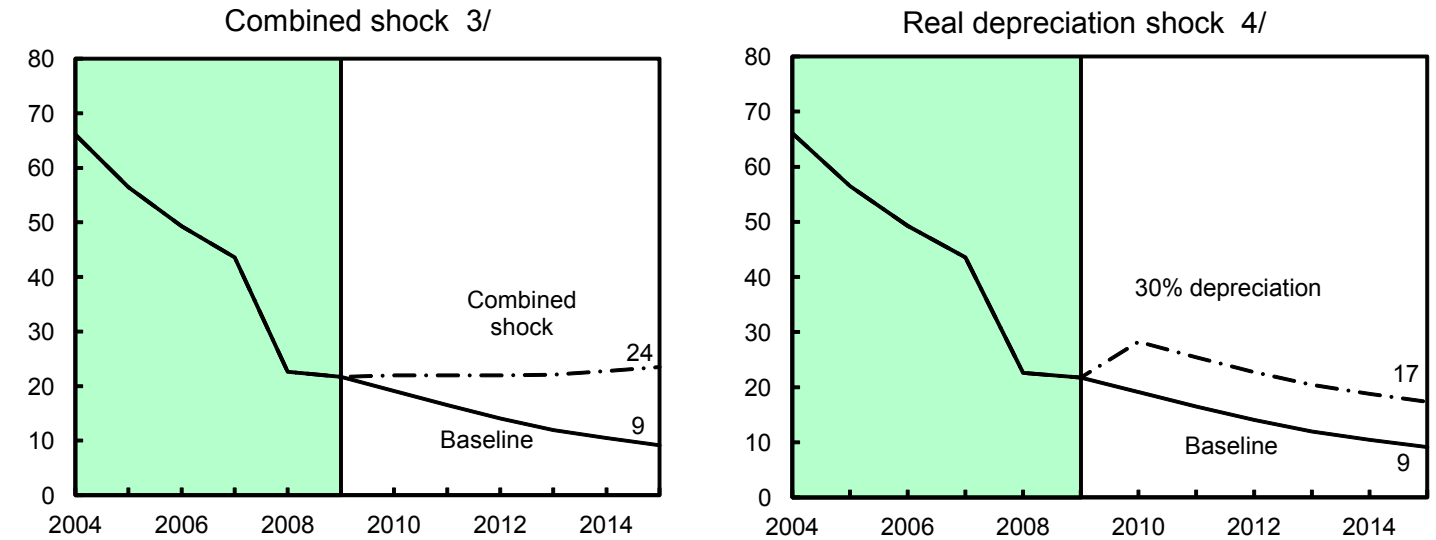

Sources: International Monetary Fund, Country desk data, and staff estimates.

1/ Shaded areas represent actual data. Individual shocks are permanent one-half standard deviation shocks. Figures in the boxes represent average projections for the respective variables in the baseline and scenario being presented. Ten-year historical average for the variable is also shown.

2/ Alternative scenario: temporary (2010-11) adverse 20 percent shock to remittances, tourism and FDI inflows.

$3 /$ Permanent $1 / 4$ standard deviation shocks applied to real interest rate, growth rate, and current account balance.

4/ One-time real depreciation of 30 percent occurs in 2010. 


\section{Appendix 7. DSGE Model of the Jordanian Economy ${ }^{1}$}

\section{Introduction}

This Appendix describes a small open-economy dynamic stochastic general equilibrium (DSGE) model developed by staff, which is used to analyze the impact of external shocks on the Jordanian economy. In line with the new-Keynesian tradition, the model features nominal and real wage and price rigidities, imperfect competition, and a Taylor-type monetary policy reaction function. To better account for the Jordanian economy's specific characteristics, the model incorporates a fully exportable commodity-producing sector (phosphate/potash), oil as an input in the production process and household consumption basket, and real exchange rate changes in the monetary policy reaction function. The impact of oil subsidies is modeled in the form of a wedge between international and domestic oil prices. Estimations are performed using Bayesian estimation techniques on quarterly data covering the period 1992-2009.

\section{Estimation results}

The model provides a good fit and yields plausible parameter estimates relative to DSGE models generated for other emerging economies. Estimations suggest a low degree of substitution between oil and other goods in the household consumption basket, and between oil and other inputs of production, underscoring the importance of oil price shocks affecting economic activity. Price and wage rigidity estimates are in line with findings in other emerging economies. The central bank policy interest rate reacts not only to the output gap and inflation, but also to real exchange rate changes. The importance of the real exchange rate for monetary policy purposes is common to other open emerging economies with fixed exchange rate regimes.

Estimation results and impulse response analysis indicate high persistence of macroeconomic variables to external shocks. The autoregressive coefficients of external shocks are above 0.7 . Strong persistence of external shocks implies that the Jordanian economy is highly vulnerable to external conditions. Illustrated below are the response of major macroeconomic variables to shocks in: (i) the international oil price; (ii) foreign demand; and (iii) demand for the exportable commodity.

\section{International oil price shock}

An international oil price shock induces a negative income effect, which translates into lower consumption of both home and foreign goods (including oil). Given low substitutability between production inputs and unchanged productivity, firms cannot substitute oil with labor and thus output declines, putting downward pressure on wages. Lower output and wages restrict household budgets and exert downward pressure on prices. The real exchange rate depreciates accordingly, and slightly improves the external position. Monetary policy reacts to the economic slowdown by reducing the nominal interest rate (see the impulse response functions of Figure 1).

\footnotetext{
${ }^{1}$ Prepared by Samya Beidas-Strom and Tigran Poghosyan (MCD).
} 
Figure 1. Response to a (one std. dev.) shock in international oil prices
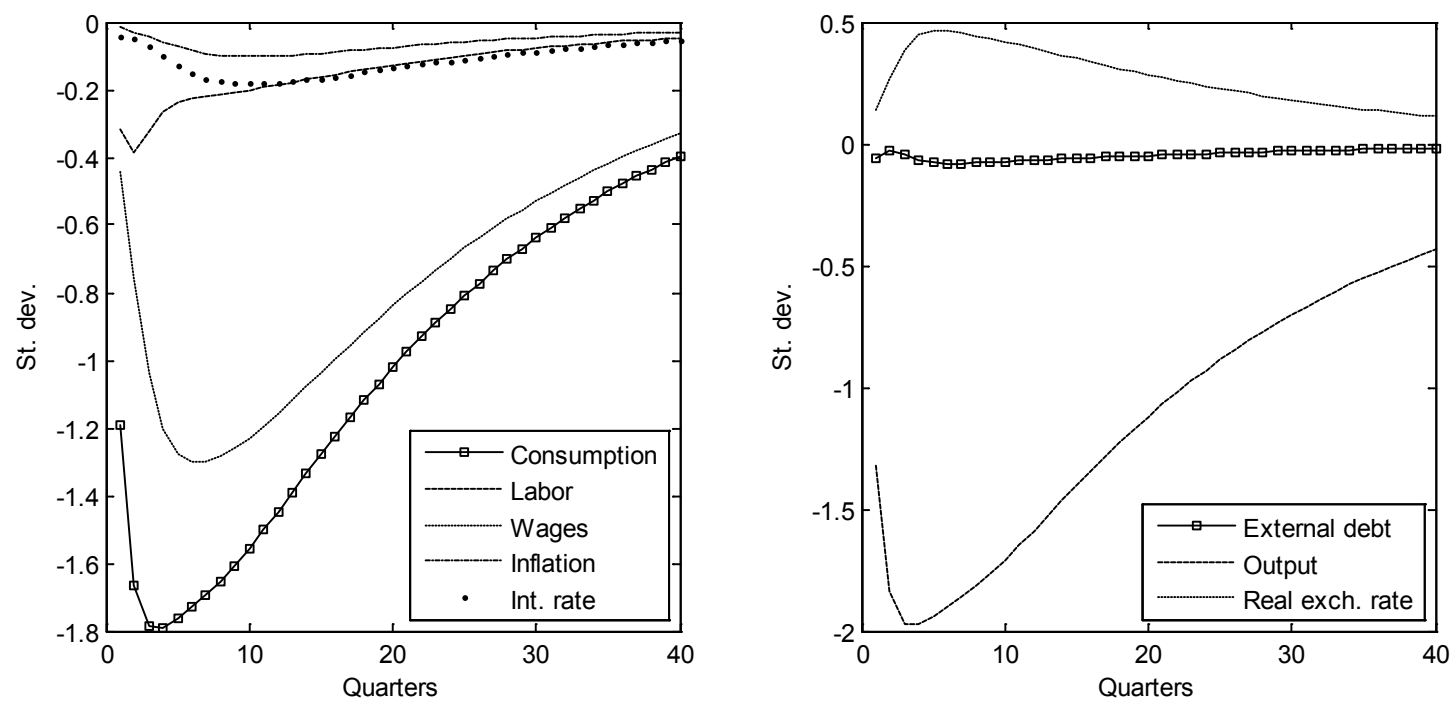

\section{Foreign demand shock}

A foreign demand shock increases domestic production and induces a positive income effect, which translates into higher consumption of both home and foreign goods. With productivity held unchanged, firms expand their output capacity by utilizing more labor and oil inputs. Given relatively low wage indexation, higher demand for labor leads to an increase in real wages, placing upward pressure on prices of home goods and inflation. The real exchange rate appreciates, slightly deteriorating the external position. Monetary policy responds to the overheating economy by raising the nominal interest rate (see Figure 2).

Figure 2. Response to a (one std. dev.) shock in foreign demand
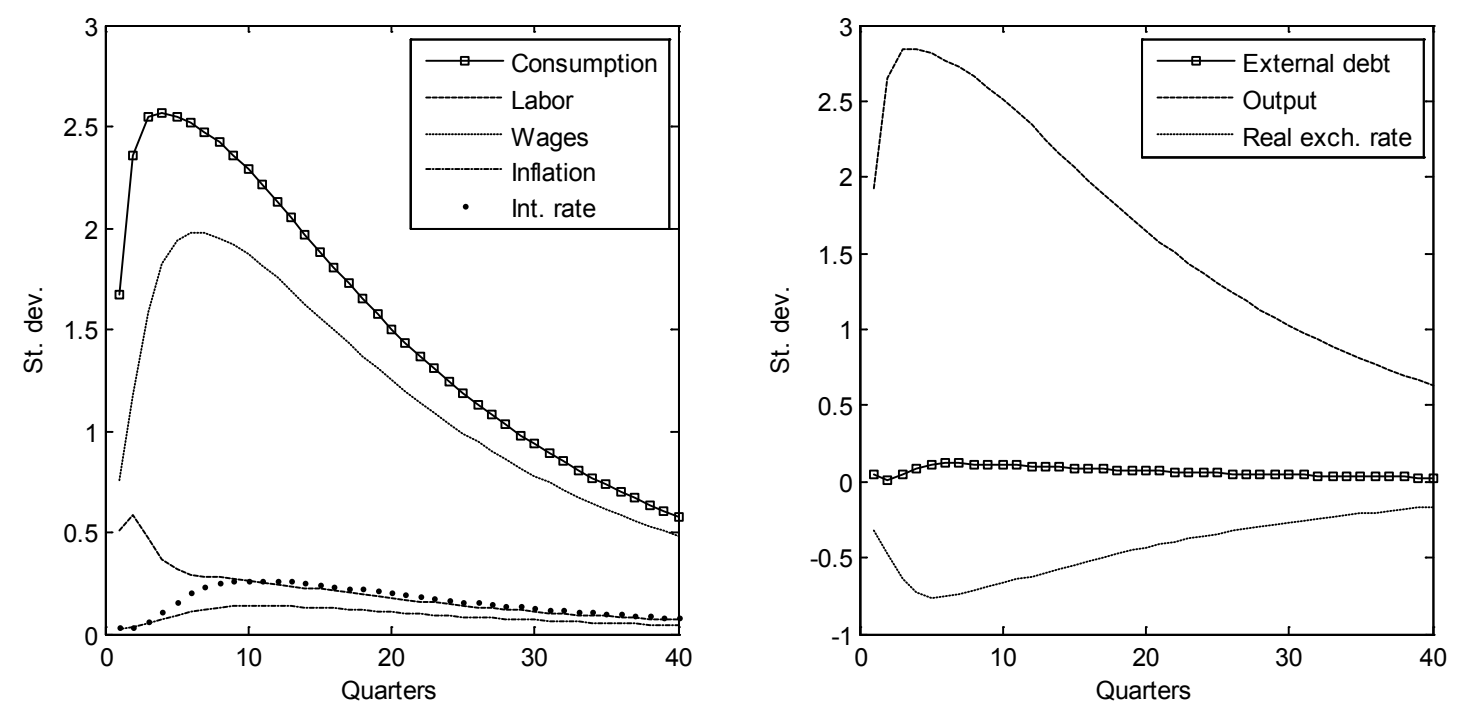


\section{Shock to demand for the exportable commodity}

A shock to demand for the exportable commodity (potash/phosphate) increases its production and induces a positive income effect, which results in higher consumption of both home and foreign goods. Firms facing higher demand for home goods increase demand for production inputs (labor and oil), leading to an increase in real wages and inflation. As with any expansion biased towards tradable goods, a boom in this sector induces a real appreciation of the exchange rate. While exports of commodity rise, net exports do not grow since the appreciation harms non-commodity exports. The real exchange rate appreciates, slightly deteriorating the external position. Monetary policy responds to the overheating economy (output and inflation) by raising the nominal interest rate (see Figure 3$)^{2}$

Figure 3. Response to a (one std. dev.) shock in demand for the exportable commodity
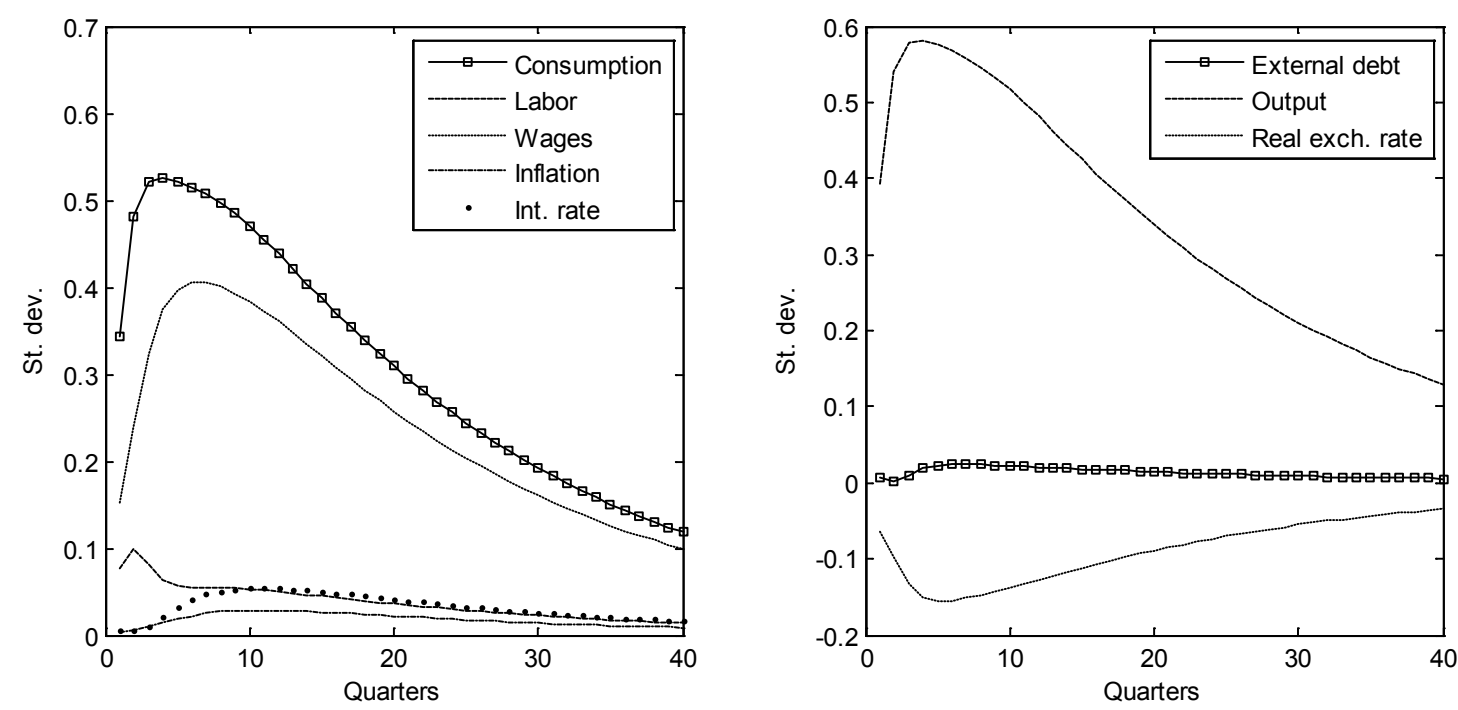

\section{Conclusion and next steps}

The analysis in this Appendix-as evidenced by the relevant impulse response functions-indicates that the estimated model describes well the main features of the Jordanian economy, particularly its openness to external shocks. Future work will focus on augmenting the model to incorporate calibrated fiscal policies in the form of a fiscal rule. In addition, capital could be added to the production function of firms, to better account for the monetary policy transmission mechanism working through interest rate changes. These modifications will improve the usefulness of the model to the Jordanian authorities as an input to economic analysis and policy formation.

\footnotetext{
${ }^{2}$ For additional details see S. Beidas-Strom and T. Poghosyan, forthcoming, "External Shocks and Economic Policies: An Estimated Dynamic Stochastic General Equilibrium Model for Jordan," IMF Working Paper (Washington: International Monetary Fund).
} 
INTERNATIONAL MONETARY FUND

JORDAN

Staff Report for the 2010 Article IV Consultation-Informational Annex

Prepared by the Middle East and Central Asia Department

(In consultation with other departments)

August 27, 2010

Contents

Page

Annexes

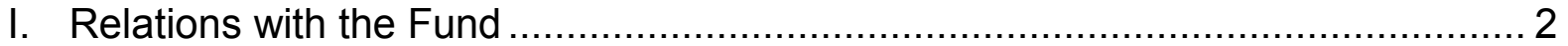

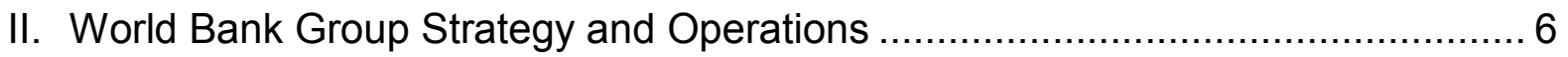

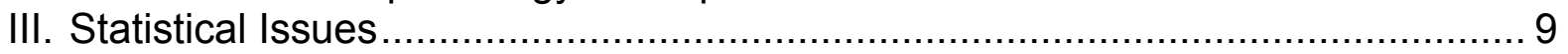




\section{Annex I. Jordan: Relations with the Fund}

(As of July 30, 2010)

I. Membership Status: Joined: August 29, 1952; Article VIII

II. General Resources Account:

SDR million

170.50

175.29

0.31

Fund holdings of currency

Reserve position in Fund

III. SDR Department:

Net cumulative allocation

Holdings

IV. Outstanding Purchases and Loans:

Extended Arrangements
SDR million

162.07

146.65

SDR million

5.07
Percent of Quota

100.00

102.81

0.18

Percent of Allocation 100.00

90.49

Percent of Quota

2.98

V. Latest Financial Arrangements:

\begin{tabular}{ccccc}
\hline Type & $\begin{array}{c}\text { Approval } \\
\text { Date }\end{array}$ & $\begin{array}{c}\text { Expiration } \\
\text { Date }\end{array}$ & $\begin{array}{c}\text { Amount Approved } \\
\text { (SDR million) }\end{array}$ & $\begin{array}{c}\text { Amount Drawn } \\
\text { (SDR million) }\end{array}$ \\
\hline SBA & $7 / 03 / 02$ & $7 / 02 / 04$ & 85.28 & 10.66 \\
EFF & $4 / 15 / 99$ & $5 / 31 / 02$ & 127.88 & 127.88 \\
EFF & $2 / 09 / 96$ & $2 / 08 / 99$ & 238.04 & 202.52 \\
\hline
\end{tabular}

VI. Projected Obligations to Fund (Expectations Basis): (SDR million; based on existing use of resources and present holdings of SDRs)

\begin{tabular}{lrrrrr}
\hline & \multicolumn{5}{c}{ Forthcoming } \\
\cline { 2 - 6 } Principal & 2010 & 2011 & 2012 & 2013 & 2014 \\
\cline { 2 - 6 } Charges/Interest & & & 5.07 & \\
\hline Total & 0.06 & 0.12 & 0.08 & 0.05 & 0.05 \\
\hline & 0.06 & 0.12 & 5.16 & 0.05 & 0.05
\end{tabular}

VII. Safeguards Assessment: Under the Fund's safeguards assessment policy, the CBJ was subject to a full assessment with respect to the Stand-By Arrangement (SBA), which was approved on July 3, 2002 and expired on July 2, 2004. The assessment was completed on June 27, 2003 and concluded that the CBJ has made progress in strengthening its safeguards, as recommended in the previous assessment of May 2001. The assessment proposed a set of measures, the majority of which have been implemented.

VIII. Exchange System: The Jordanian dinar is fully convertible and is officially pegged to the SDR. In practice, the authorities have an exchange rate regime which is pegged to the U.S. dollar since October 1995 at JD $1=\$ 1.41044$. Jordan accepted the obligations of Article VIII, Sections 2, 
3, and 4 in 1995 and maintains an exchange system free of restrictions on payments and transfers for current international transactions.

IX. Article IV Consultation: The 2009 Article IV consultation was concluded by the Executive Board on May 4, 2009. The Staff Report and Summing Up of the Executive Directors' discussions and policy recommendations can be found in IMF Country Report 09/159 at:

http://www.imf.org/external/pubs/cat/longres.cfm?sk+22965.0

X. Technical Assistance: Extensive technical assistance has been provided to Jordan over recent years (see attached table).

XI. Documents:

Standards or Codes Assessed

Data module

FSSA

Update to data module

Fiscal transparency module
Date of Issuance

10/8/2002

$1 / 7 / 2004$

$1 / 30 / 2004$

$1 / 9 / 2006$ 
Jordan: Technical Assistance, 2002-10

\begin{tabular}{|c|c|}
\hline Date & Purpose \\
\hline \multicolumn{2}{|l|}{ Fiscal } \\
\hline January-June 2002 & Pension reform \\
\hline January-September 2002 & GST reform \\
\hline November 2002 & Macrofiscal capacity and treasury single account \\
\hline February, October 2003 & Revenue administration reform \\
\hline June, August, December 2003 & Peripatetic advisor on single treasury account \\
\hline February, June, October 2004 & Peripatetic advisor on revenue administration reform \\
\hline February, May 2004 & Public expenditure management \\
\hline August 2004-June 2005 & Resident expert in macrofiscal management \\
\hline February 2005 & Distributional effects of replacing oil subsidies \\
\hline February-March 2005 & Revenue administration reform \\
\hline April 2005 & Fiscal ROSC \\
\hline February, May 2006 & Public financial management \\
\hline April-August 2006 & Expert visits on revenue administration reform \\
\hline October-November 2006 & Revenue administration inspection visit \\
\hline March-April, July, December 2007 & Revenue administration reform (METAC) \\
\hline June 2008 & Treasury single account and cash management (METAC) \\
\hline February 2009 & Sustainable expenditures \\
\hline March 2009 & Tax policy review \\
\hline July-August 2009 & Public financial management reform (with World Bank) \\
\hline February 2010 & Expert visit to assess progress in implementing revenue reforms \\
\hline February 2010 & Options for short term expenditure rationalization \\
\hline March 2010 & Tax policy review \\
\hline March 2010 & Public financial management (METAC) \\
\hline March-April 2010 & Commitment control system (METAC) \\
\hline \multicolumn{2}{|l|}{ Monetary and Financial } \\
\hline August-September 2003 & Financial Sector Assessment Program (FSAP) \\
\hline April-May 2008 & Debt management strategy \\
\hline August 2008 & Review the existing budgetary system in CBJ \\
\hline November 2008 & FSAP update \\
\hline June 2010 & Strengthening public debt management \\
\hline October 2009 & Developing the government domestic Sukuk market \\
\hline July 2010 & Implementation of BASEL II \\
\hline July 2010 & Developing credit bureau regulations (METAC) \\
\hline
\end{tabular}




\section{Statistical}

January-February 2002

December 2003

October 2003-January 2004, March-May 2004

April-May 2004

December 2006

October-November 2006

July 2007

October 2008

February 2009

December 2009

Other

March 2008

February 2010

April 2010

July 2010
Report on the observation of standards and codes-data module Follow-up on report on the observation of standards and codesdata module

Balance of payments statistics

Government finance statistics

National accounts statistics

SDDS assessment mission

Follow-up on SDDS/Government finance statistics

Monetary and financial statistics

National accounts statistics (METAC)

Special data dissemination standard assessment

Financial programming workshop

Safeguards and fiscal investment (FIN)

Outreach mission-Visit of Managing Director and IMF Middle East Youth Dialog (EXR)

Central Bank of Jordan-IMF research workshop (MCD) 


\section{Annex II. Jordan: World Bank Group Strategy and Operations}

1. As of July 8, 2010, the World Bank has approved 66 loans, 15 credits and five grants for a total of US $\$ 3,007.2$ million. Of the 66 loans, nine are for budget support operations (Development Policy Loans (DPLs)). The most recent DPL for US $\$ 300$ million was approved by the Bank's Board on November 19, 2009. The current portfolio consists of seven active investment projects and one guarantee operation for a total net commitment of US $\$ 288.5$ million with an undisbursed balance of US $\$ 164.9$ million. Overall performance of the portfolio is good, both from the perspective of implementation and development impact. This reflects the generally good project implementation capacity of Jordanian institutions, Jordan's strong ownership of the program, and the quality of the dialogue between the Bank and the Government of Jordan (GoJ).

2. The Joint World Bank-IFC country assistance strategy (CAS) for FY 2006-10, endorsed by the Bank's Executive Board in May 2006, was aligned with the government priorities of poverty alleviation and the creation of higher productivity jobs, while assisting the country in its transition through the medium-term economic shocks. The CAS set out a four-year program organized in four cross-sectoral clusters:

- $\quad$ strengthening the investment environment and building human resources for value-added, skillintensive, and knowledge-based economy;

- supporting local development through increased access to services and economic opportunities;

- $\quad$ reforming social assistance and expanding inclusion; and

- restructuring public expenditures and supporting public sector reform.

3. In the CAS period (FY2006-10), the Bank approved six investment loans, one supplemental, and one development policy loan for a total commitment amount of US $\$ 505.5$ million. The loans focus on assisting Jordan achieve regionally balanced and equitable growth including access to services, employment opportunities, and private investments outside Amman, enhancing social protection, reforming the vocational and training sector, and on supporting the implementation of the Government's medium-term development program in the context of the current global financial crisis and economic slowdown. The GoJ has also sought technical support from the Bank (many underpinned by diagnostic work). The Bank provided programmatic technical support in key areas, including public expenditure management, social insurance, poverty monitoring, and energy sector reform.

4. The World Bank Group (WBG) team is currently preparing a new Country Partnership Strategy (CPS) for FY 2011-14 with the overarching goal "strengthening resilience for sustainable growth". It envisages supporting the Jordanian economy by seeking sources of endogenous growth that maximize the country's comparative advantages in the region while reducing its dependence on external financial flows (aid, investment, remittances). It supports the Government's central objectives of growth generation, poverty reduction and social inclusion as expressed in the National Agenda and the newly developed Executive Plan.

5. The following three interlinked strategic clusters, which build on the new Executive agenda of the GoJ and are directly aligned with the overarching objective of the CPS, are proposed to guide the consultation process: 
- Cluster 1: Greater efficiency and capacity of public sector (including public expenditures, improved fiscal management and improved service delivery to all stakeholders);

- Cluster 2: Enabling environment for private sector development, including investment in strategic infrastructure through the use of PPPs and improvements to the investment climate as well as reforming and modernizing public procurement.

- Cluster 3: Enhanced human development and social stability through better quality education (better matched to labor market needs) and targeted assistance to the poor.

6. Although the clusters are presented separately, the linkages between the sectors and the interlinked reform agendas will be emphasized. Throughout the preparation and implementation of the CPS, the WBG will make use of its comparative advantage of working in an integrated manner on the cross-sectoral issues such as gender and regional integration. The CPS envelope is at this stage indicative but will possibly include technical assistance, budget support and analytical services that reflect the emerging needs with respect to short-term financial challenges and longer-term institutional developments.

7. World Bank Group support to private sector development will continue to focus on improving the investment environment, public private partnership, partial risk guarantees for major projects (envisaged to attract private sector participation and to provide a better financial package for critical projects in water and energy), and, in the case of IFC, direct investment. IFC is playing a key role in supporting most of the strategic projects in Jordan. The GoJ has brought a number of key infrastructure projects to the market for private participation. IFC is well positioned to support and mobilize financing to a number of these projects. The IFC's advisory activities in Jordan intend to fill the gaps and address critical areas for private sector development, such as improving the investment climate. 
8. The Bank and IMF continue to collaborate in supporting the authorities in the following areas:

Jordan: JMAP Implementation, FY2011-12

\begin{tabular}{|c|c|c|c|}
\hline Title & Products & $\begin{array}{l}\text { Provisional Timing } \\
\text { of Missions }\end{array}$ & $\begin{array}{l}\text { Expected Delivery } \\
\text { Date }\end{array}$ \\
\hline \multicolumn{4}{|c|}{ A. Mutual Information on Relevant Work Programs } \\
\hline $\begin{array}{l}\text { Bank work } \\
\text { program }\end{array}$ & $\begin{array}{l}\text { Country Partnership Strategy } \\
\text { (CPS) } \\
\text { Development Poverty Review - } \\
\text { Growth and Competitiveness } \\
\text { PFM TA (MTEF and budget } \\
\text { preparation) } \\
\text { Public Sector Reform TA } \\
\text { Poverty TA } \\
\text { Sector work on the social } \\
\text { safety net, energy, and PPP } \\
\text { framework }\end{array}$ & $\begin{array}{l}\text { Main Mission } \\
\text { September } 2010 \\
\text { Initiation mission in } \\
\text { Summer } 2011 \\
\text { Initiation mission in } \\
\text { Summer } 2011 \\
\text { Fall 2011 } \\
\text { FY2011-12 } \\
\text { FY2011-12 }\end{array}$ & $\begin{array}{l}\text { Board Discussion } \\
\text { March } 2011 \\
\text { Implementation } \\
\text { throughout FY2011-12 } \\
\text { Implementation } \\
\text { throughout FY2011-12 } \\
\text { Implementation } \\
\text { throughout FY2011-12 } \\
\text { Implementation } \\
\text { throughout FY2012 } \\
\text { Implementation } \\
\text { throughout FY2012 }\end{array}$ \\
\hline $\begin{array}{l}\text { IMF work } \\
\text { program }\end{array}$ & $\begin{array}{l}\text { Staff visit (budget discussion) } \\
\text { Article IV consultation }\end{array}$ & $\begin{array}{l}\text { December } 2010 \\
\text { May } 2011\end{array}$ & $\begin{array}{l}\text { December } 2010 \\
\text { May } 2011\end{array}$ \\
\hline \multicolumn{4}{|c|}{ B. Requests for Work Program Inputs (as needed) } \\
\hline $\begin{array}{l}\text { Fund request } \\
\text { to Bank }\end{array}$ & $\begin{array}{l}\text { Information sharing (related to } \\
\text { economic work and technical } \\
\text { assistance) }\end{array}$ & Ongoing & \\
\hline $\begin{array}{l}\text { Bank request } \\
\text { to Fund }\end{array}$ & $\begin{array}{l}\text { Development Policy Loan (will } \\
\text { require input from Fund) }\end{array}$ & $\begin{array}{l}\text { Scoping mission } \\
\text { August } 1,2010 . \\
\text { Additional missions } \\
\text { Fall } 2010\end{array}$ & Fall 2010 \\
\hline
\end{tabular}




\section{Annex III. Jordan: Statistical Issues}

(As of July 30, 2010)

\section{Assessment of Data Adequacy for Surveillance}

General: Data provision is adequate for surveillance purposes.

National Accounts: During the past few years, progress has been made toward enhancing the quality of national accounts statistics. Continued improvement requires a strong commitment and allocation of additional resources. Additional efforts are needed to improve quarterly estimates of the national accounts from the production approach and the annual estimates from the expenditure approach, as well as the coverage of informal activities. Also, discrepancies between the industrial production index and the gross value added estimates for the manufacturing sector need to be addressed. New surveys have been implemented to improve the compilation and timeliness of wages and earnings data.

Government finance. The authorities have initiated work aimed at developing a financial balance sheet in accordance with the classification and sectorization systems recommended by the GFSM 2001 aimed at further strengthening the stock and flow data that serve as a source for compiling government finance statistics and for verification of internal and intersectoral consistency.

Monetary statistics: The Central Bank of Jordan (CBJ) informed the 2003 data ROSC Update mission that the CBJ Research Department, which is responsible for the collection and compilation of the monetary statistics, proposed the establishment of an interagency group to monitor the intersectoral consistency of macroeconomic statistics. However, consistency checks between government finance statistics and monetary statistics are not yet conducted. Timeliness of reporting monetary data for publication in International Financial Statistics is satisfactory. However, little progress has been achieved so far in implementing the Standardized Report Forms for reporting monetary data to the Fund.

Balance of payments: The CBJ has adopted the methodology of the fifth edition of the Balance of Payments Manual (BPM5) for the compilation of the BOP statistics and the international investment position (IIP), and has disseminated data in the BPM5 format. The implementation of surveys in the area of services is important for further improving the quality of the BOP statistics. In mid-2010 the CBJ revised the historical BOP data (2000-08) to address the sharp increase in errors and omissions.

\section{Data Standards and Quality}

Subscriber to the Fund's Special Data Dissemination Standard (SDDS) since Data ROSC update was published in January 2010. Uses SDDS flexibility option on the periodicity and timeliness of the labor market wages/earnings data. 
Jordan: Common Indicators Required For Surveillance

(As of July 30, 2010)

\begin{tabular}{|c|c|c|c|c|c|c|c|}
\hline & Date of & Date & Frequency & Frequency & Frequency & Memo It & \\
\hline & $\begin{array}{c}\text { Latest } \\
\text { Observation }\end{array}$ & Received & $\begin{array}{c}\text { of } \\
\text { Data } 7 /\end{array}$ & $\begin{array}{c}\text { of } \\
\text { Reporting } 71\end{array}$ & $\begin{array}{c}\text { of } \\
\text { Reporting } 7 /\end{array}$ & $\begin{array}{l}\text { Data quality-methodological } \\
\text { soundness } 8 /\end{array}$ & $\begin{array}{l}\text { Data quality-accuracy } \\
\text { and reliability } 9 /\end{array}$ \\
\hline Exchange rates & July 2010 & July 2010 & W & $\mathrm{M}$ & W & & \\
\hline $\begin{array}{l}\text { International reserve assets and reserve } \\
\text { liabilities of the monetary authorities } 1 /\end{array}$ & June 210 & June 2010 & W & M & M & & \\
\hline Reserve/base money & May 2010 & May 2010 & $\mathrm{M}$ & M & $\mathrm{M}$ & & \\
\hline Broad money & May 2010 & May 2010 & $M$ & $M$ & $M$ & & \\
\hline Central bank balance sheet & May 2010 & May 2010 & $\mathrm{M}$ & $\mathrm{M}$ & $\mathrm{M}$ & & \\
\hline $\begin{array}{l}\text { Consolidated balance sheet of the banking } \\
\text { system }\end{array}$ & May 2010 & May 2010 & M & M & M & O, O, LO, LO & O, LO, O, O, LO \\
\hline Interest rates $2 /$ & July 2010 & July 2010 & W & $M$ & W & & \\
\hline Consumer price index & June 2010 & July 2010 & $\mathrm{M}$ & M & $\mathrm{M}$ & $\mathrm{O}, \mathrm{LO}, \mathrm{O}, \mathrm{O}$ & $\mathrm{O}, \mathrm{LO}, \mathrm{O}, \mathrm{O}, \mathrm{O}$ \\
\hline $\begin{array}{l}\text { Revenue, expenditure, balance and composition } \\
\text { of financing } 3 / \text {-general government } 4 /\end{array}$ & 2008 & July 2010 & A & A & A & & \\
\hline $\begin{array}{l}\text { Revenue, expenditure, balance and composition } \\
\text { of financing } 3 / \text { - central government }\end{array}$ & May 2010 & July 2010 & M & M & M & O, LO, LNO, O & $\mathrm{O}, \mathrm{O}, \mathrm{O}, \mathrm{O}, \mathrm{NA}$ \\
\hline $\begin{array}{l}\text { Stocks of central government and central } \\
\text { government-guaranteed debt } 5 /\end{array}$ & May 2008 & July 2010 & M & M & M & & \\
\hline External current account balance & Q1 2010 & June 2010 & Q & Q & Q & & \\
\hline Exports and imports of goods and services & May 2010 & July 2010 & M & M & Q & LNO, LNO, LNO, LO & LNO, LO, LO, LO, LO \\
\hline GDP/GNP & Q1 2010 & July 2010 & Q & Q & $Q$ & $\mathrm{O}, \mathrm{LO}, \mathrm{O}, \mathrm{O}$ & $\mathrm{O}, \mathrm{LO}, \mathrm{O}, \mathrm{LO}, \mathrm{LO}$ \\
\hline Gross external debt & May 2010 & July 2010 & $\mathrm{M}$ & M & $\mathrm{M}$ & & \\
\hline International Investment Position 6/ & 2008 & June 2010 & A & A & $\mathrm{M}$ & & \\
\hline
\end{tabular}

$1 /$ Any reserve assets that are pledged or otherwise encumbered should be specified separately. Also, data should comprise short-term liabilities linked to a foreign currency but settled by other means as well as the notional values of financial derivatives to pay and to receive foreign currency, including those linked to a foreign currency but settled by other means. 2/ Both market-based and officially-determined, including discount rates, money market rates, rates on treasury bills, notes and bonds.

$3 /$ Foreign, domestic bank, and domestic nonbank financing.

4/ The general government consists of the central government (budgetary funds, extrabudgetary funds, and social security funds) and state and local governments. $5 /$ Including currency and maturity composition.

6/ Includes external gross financial asset and liability positions vis-à-vis nonresidents.

7/ Daily (D); weekly (W); monthly (M); quarterly (Q); annually (A); irregular (I); not available (NA).

$8 /$ Reflects the assessment provided in the substantive update of the data ROSC published in February 2004 for the dataset corresponding to the variable in each row. The assessment indicates whether international standards concerning (respectively) concepts and definitions, scope, classification/sectorization, and basis for recording are fully observed (O), largely observed (LO), largely not observed (LNO), not observed (NO), or not available (NA).

9/ Same as footnote 7, except referring to international standards concerning (respectively) source data, statistical techniques, assessment and validation of source data, assessment and validation of intermediate data and statistical outputs, and revision studies. 


\section{INTERNATIONAL MONETARY FUND}

Public Information Notice

EXTERNAL

RELATIONS

DEPARTMENT
Public Information Notice (PIN) No. 10/131

FOR IMMEDIATE RELEASE

September 17, 2010
International Monetary Fund

$70019^{\text {th }}$ Street, NW

Washington, D. C. 20431 USA

\section{IMF Executive Board Concludes 2010 Article IV Consultation with Jordan}

On September 15, 2010, the Executive Board of the International Monetary Fund (IMF) concluded the 2010 Article IV consultation ${ }^{1}$ with Jordan on a lapse of time basis. Under the IMF's lapse of time procedures, the Executive Board completes Article IV consultations without convening formal discussions.

\section{Background}

The global economic downturn adversely affected economic activity in Jordan. Real Gross Domestic Product (GDP) growth fell from almost 71/3 percent in 2008 to 21/3 percent in 2009, mainly due to weaker activity in the finance, manufacturing, and trade sectors. Headline inflation declined steadily through 2009 to near zero, in line with lower commodity prices worldwide, although core inflation has remained stable at around 3 percent year on year by December 2009. For 2010 headline inflation is projected to increase in line with imported commodity (energy and food) prices.

Lower commodity prices helped improve Jordan's external position. The current account deficit narrowed to 5 percent of GDP in 2009 (from 91/2 percent in 2008), on the back of strong tourism receipts and remittances and lower oil imports. Foreign direct investment (FDI) and other

\footnotetext{
${ }^{1}$ Under Article IV of the IMF's Articles of Agreement, the IMF holds bilateral discussions with members, usually every year. A staff team visits the country, collects economic and financial information, and discusses with officials the country's economic developments and policies. On return to headquarters, the staff prepares a report, which forms the basis for discussion by the Executive Board. At the conclusion of the discussion, the Managing Director, as Chairman of the Board, summarizes the views of Executive Directors, and this summary is transmitted to the country's authorities. An explanation of any qualifiers used in summings up can be found here: http://www.imf.org/external/np/sec/misc/qualifiers.htm.
} 
inflows comfortably financed the current account deficit, and allowed official foreign reserves to reach a record high of US\$11 billion (equivalent to eight months of imports) by end-2009.

Similar to many emerging market countries adversely affected by the global growth downturn, Jordan's already-difficult 2009 fiscal position worsened due to a significant deterioration in external grants. While an increase in capital spending - to support domestic activity —was largely offset by lower commodity subsidies, a cyclical weakening in domestic revenues and a dramatic downturn in external grants induced a widening of the overall deficit by more than 3 percentage points of GDP, reaching $8 \frac{1}{2}$ percent of GDP in 2009. As a result, the debt-to-GDP ratio rose to about 56 percent at end-2009.

The government responded to the growth downturn with effective fiscal consolidation measures. Based on the latest developments and macroeconomic assumptions, the 2010 overall deficit is expected to narrow by more than 2 percent of GDP relative to the 2009 outturn, reaching about 6 percent of GDP. With lower projected grant receipts and the continued cyclical decline in tax revenues, the consolidation will come mainly from the spending side-involving greater prioritization of capital spending and savings in current expenditures, including from containment of the public sector wage bill and reductions in the operating costs of public institutions and independent agencies. Implementation of these fiscal plans would result in a modest uptick in the public debt-to-GDP ratio, which would nonetheless remain below the 60 -percent legislated debt ceiling.

The Central Bank of Jordan (CBJ) has successfully maintained financial stability by undertaking a series of forceful measures to support growth of private sector credit and moderate the impact of the slowdown. Starting in 2008, the authorities responded to the downturn in domestic credit by: issuing a full guarantee of bank deposits, which has been extended until end-2010; ceasing liquidity-withdrawal operations (through CBJ sales of certificates of deposit) in October 2008; and gradually reducing reserve requirements and policy interest rates between November 2008 and February 2010, thereby reducing the interest rate differential against the U.S. Federal Reserve's funds rate from 450 to 200 basis points. Deposit growth has remained healthy, and the share of dinar-denominated deposits has continued to increase.

Private sector credit growth turned positive at end-2009, reaching 51/2 percent year on year in May 2010. Contributions from credit to construction, tourism, and trade sectors have been increasing since their lowest point in September 2009. Following the latest (February 2010) cuts in the policy rate, the accumulation of excess liquidity in the overnight window of the CBJ has reversed. Encouraged by declining interest rate spreads relative to advanced countries, international reserves have stabilized at historically-high levels. The Jordanian dinar real effective exchange rate has appreciated by $2 \frac{1}{2}$ percent between December 2008 and June 2010, mainly due to the strengthening of the U.S. dollar against major currencies. 
The Jordanian banking system remains sound and has proven resilient to the global financial crisis. The CBJ's prudent banking regulation and supervision, and banks' conservative funding practices (with loan/deposit ratio near 75 percent) have shielded domestic banks from exposure to troubled international banks, structured products, and wholesale financial markets. The banking sector's macroprudential indicators remain strong-banks remain profitable and well capitalized, deposits continue to be the major funding base, liquidity ratios and provisioning remain high, while non-performing loans (NPL) ratios increased modestly to $62 / 3$ percent of outstanding loans at end-2009.

Effective banking supervision has strengthened the capacity of Jordanian banks to withstand shocks. The CBJ has taken steps to further enhance its effective banking regulation and supervision by: (i) introduction of Basle II (Pillars I and III) regulations in 2008, and ongoing efforts to ensure compliance of banks with Pillar II guidelines for risk management; (ii) requiring semi-annual stress testing of banks, examining in particular credit risk and concentration risk; (iii) introduction of an automated data collection system, to improve off-site monitoring of banks; (iv) enhanced cross-border bank regulation through regular supervision and on-site inspections of international branches and subsidiaries of Jordanian banks; and (v) improvements to its early warning system.

\section{Executive Board Assessment}

In concluding the 2010 Article IV consultation with Jordan, Executive Directors endorsed staff's appraisal, as follows:

Following a decade of strong growth, the Jordanian economy has slowed, largely due to the global and regional downturn. Economic activity is expected to pick up modestly in 2010, and accelerate further over the medium-term, as growth revives in key regional trading partners, bringing Jordanian output closer to potential.

The authorities have implemented prudent fiscal and monetary policies, which have ensured fiscal sustainability and supported the domestic financial system. Even in the presence of a cyclical downturn in economic activity, the government has proceeded with its fiscal consolidation plans for 2010 and the medium term. Fully implemented, this should contribute to a significant reduction in the debt-to-GDP ratio, and provide for a major amelioration of fiscal vulnerabilities. Similarly, the monetary authorities implemented cautious monetary easing in the period between late-2008 and early-2010, in an effort to raise private sector credit flows, and also took the opportunity provided by abundant capital inflows to bolster international reserves.

In view of the shortfall in external grants and the authorities' desire to signal to markets their seriousness in ensuring fiscal sustainability, the staff supports the fiscal consolidation envisaged in the 2010 Budget. Staff believes that the decline in the overall deficit of about 2 percent of 
GDP this year is both appropriate and achievable, and would leave fiscal room for an envisaged increase in social expenditures, while maintaining sizeable capital expenditures. While implementation of these fiscal plans would result in a small rise in the public debt-to-GDP ratio in 2010 , it would still remain below the 60 percent legislated debt ceiling.

The authorities' objective of reducing the fiscal deficit to about 3 percent of GDP over the medium term is critical to achieving private sector-led growth and reducing vulnerabilities. Reducing the overall deficit by about 3 percent of GDP over the next five years is feasible, based on the experience of other countries, and would lead to a further 5 percentage point decline in Jordan's debt-to-GDP ratio. Such adjustment will be crucial to maintain investor confidence, preserve macroeconomic stability, and create scope for future countercyclical fiscal policy. Efficiency gains in both revenue-raising and expenditure will help durably address Jordan's main fiscal vulnerabilities. Priorities include removing remaining tax exemptions on commodities, ongoing prioritization of capital spending, and continued moderation of growth in the public sector wage bill.

Significant progress has been made in advancing structural reforms, yet the Jordanian authorities continue to face a number of policy challenges. In the near-term, further improvement in the business environment for the private sector will be key to raising productivity and building upon Jordan's external competitiveness. Staff supports the recent enhancements to income taxation and investment policy, and recommends that additional reform priorities include further liberalization of important business inputs (particularly energy and water sectors), as well as the achievement of greater public sector efficiencies through implementation of civil service reforms.

The medium-term fiscal strategy should be supported by a number of institutional reforms. These include strengthening tax administration and reenergizing the implementation of public sector financial management reforms. In an effort to relieve infrastructure bottlenecks, the authorities plan an ambitious medium-term program of large-scale infrastructure development, to be largely financed by public-private partnerships (PPPs). As an important prior action, the staff recommends that a strong framework needs to be put in place to minimize the risk of contingent liabilities stemming from PPPs.

Monetary policy has rightly focused on monetary easing in 2009-10 to stimulate domestic demand, yet there should now be a pause on further monetary stimulus. Since late 2008 the authorities have taken several steps to support the domestic financial system, including multiple reductions in the policy rate and cessation of issuance of certificates of deposit. Jordan's current stock of international reserves is large and stable, and given the growing turnaround in private sector credit flows and some evidence of emerging inflationary pressures, the staff recommends that the monetary authorities stand ready to tighten monetary conditions as appropriate. 
The fixed exchange rate regime remains important for financial stability. The Jordanian dinar's peg to the U.S. dollar has acted as an appropriate nominal anchor for the economy. Analysis by the staff of the real effective exchange rate indicates that the dinar remains broadly aligned with its medium-term fundamentals. In addition, the risk of external instability emanating from the capital account is lowered by the fact that most external debt consists of obligations to official creditors, and reserves far exceed short-term external liabilities.

Bank regulation and supervision should continue to focus on preventing excessive risk taking. The banks' conservative funding and asset structures, underpinned by effective banking supervision and regulation, have limited exposures to adverse global liquidity conditions. As a consequence, the banking sector's macroprudential indicators remain strong. Nonetheless, bank supervision and regulation should remain vigilant, as Jordanian banks could be exposed to higher non-performing loans and provision requirements in the coming years, as output growth is likely to remain below trend until 2012.

Given Jordan's large stock of debt, it will be important to have clear, timely and proactive communication of policy intentions for debt reduction and debt management, in large part to build ownership for necessary fiscal reforms. Communication of the government's medium-term debt management strategy will be particularly relevant, as will enhancements to the primary and secondary markets for public debt.

While substantial progress in improving data quality and coverage has occurred in recent years, the statistical system needs to be further improved. Jordan is to be congratulated for its January 2010 subscription to the IMF's Special Data Dissemination Standard. Nonetheless, data inadequacies persist, particularly in the areas of the expenditure side of the national accounts, and in employment and wage statistics, which continue to hamper economic analysis and policy formation. The staff urges greater progress in resolving these inadequacies.

Public Information Notices (PINs) form part of the IMF's efforts to promote transparency of the IMF's views and analysis of economic developments and policies. With the consent of the country (or countries) concerned, PINs are issued after Executive Board discussions of Article IV consultations with member countries, of its surveillance of developments at the regional level, of post-program monitoring, and of ex post assessments of member countries with longer-term program engagements. PINs are also issued after Executive Board discussions of general policy matters, unless otherwise decided by the Executive Board in a particular case. 
Jordan: Selected Economic Indicators

\begin{tabular}{|c|c|c|c|c|}
\hline & 2007 & 2008 & $\begin{array}{l}\text { Prel. } \\
2009 \\
\end{array}$ & $\begin{array}{l}\text { Proj. } \\
2010 \\
\end{array}$ \\
\hline Real sector & \multicolumn{4}{|c|}{ (Annual percentage changes) } \\
\hline Real GDP at market prices & 8.9 & 7.2 & 2.3 & 3.4 \\
\hline Consumer price index (average) & 5.4 & 14.9 & -0.7 & 5.7 \\
\hline Unemployment rate (percent) & 13.1 & 12.7 & 13.0 & $\ldots$ \\
\hline Gross domestic investment (in percent of GDP) & 30.6 & 24.9 & 23.0 & 21.4 \\
\hline Gross national savings (in percent of GDP) & 13.0 & 15.3 & 18.0 & 14.4 \\
\hline Public finance & \multicolumn{4}{|c|}{ (In percent of GDP) } \\
\hline Central government revenue and grants & 32.5 & 29.1 & 25.1 & 23.3 \\
\hline Of which: grants & 2.8 & 4.5 & 1.9 & 1.6 \\
\hline Central government expenditure and net lending ${ }^{1}$ & 38.3 & 34.5 & 33.6 & 29.5 \\
\hline grants & -5.8 & -5.4 & -8.5 & -6.2 \\
\hline Government and government-guaranteed net debt & 68.0 & 52.9 & 55.8 & 57.3 \\
\hline Balance of payments & \multicolumn{4}{|c|}{ (In percent of GDP) } \\
\hline Current account balance (after grants), of which: & -17.6 & -9.6 & -5.0 & -7.0 \\
\hline Exports, f.o.b. (\$ billions) & 5.7 & 7.9 & 6.4 & 6.6 \\
\hline Imports, f.o.b. (\$ billions) & 12.2 & 15.1 & 12.5 & 13.5 \\
\hline Gross usable international reserves (\$ millions) ${ }^{2}$ & 6,865 & 7,732 & 11,093 & 10,705 \\
\hline In months of prospective import cover & 4.7 & 6.2 & 8.1 & 7.4 \\
\hline Relative to short-term debt by remaining maturity & 7.9 & 11.6 & 18.4 & 15.7 \\
\hline Money and credit & \multicolumn{4}{|c|}{ (Annual percentage changes) } \\
\hline Broad money & 10.6 & 17.3 & 9.3 & 9.9 \\
\hline Credit to private sector & 15.3 & 14.8 & 0.5 & 7.9 \\
\hline \multicolumn{5}{|l|}{ Exchange rates } \\
\hline U.S. dollar per Jordanian dinar (end-period) & 1.4 & 1.4 & 1.4 & 1.4 \\
\hline Real effective exchange rate (percent change) ${ }^{3}$ & -3.8 & 12.2 & -4.4 & $\ldots$ \\
\hline
\end{tabular}

Sources: Jordanian authorities; and IMF staff estimates and projections.

${ }^{1}$ Including off-budget.

${ }^{2}$ Net of short-term foreign liabilities, foreign currency swaps, and commercial bank foreign deposits with the Central Bank of Jordan.

${ }^{3}$ End of period; a positive number indicates an appreciation. 